\author{
UNIVERSIDADE DE SÃO PAULO \\ FACULDADE DE SAÚDE PUBLICA \\ DEPARTAMENTO DE PRÁTICA DE SAÚDE PÚBLICA
}

\title{
O COMPROMETIMENTO DE PESSOAS INTEGRADAS A UM SISTEMA DE BIBLIOTECAS UNIVERSIT ÁRIAS
}

Tese apresentada ao Departamento de Prática de Saúde Pública, da Faculdade de Saúde Pública da Universidade de São Paulo, para obtenção do grau de Doutor em Saúde Pública

Área de concentração: Serviços de Saúde Pública

Aluna: Maria Fazanelli Crestana

Orientador: Prof $^{\underline{a}}$ Dr $^{\underline{a}}$ Vitoria Kedy Cornetta 
“... Nem tudo é verdadeiro, mas em todo lugar e a todo momento existe uma verdade a ser dita e a ser vista, uma verdade talvez adormecida, mas que, no entanto, está somente à espera de nosso olhar para aparecer, à espera de nossa mão para ser desvelada. A nós cabe achar as boas perspectivas, o ângulo correto, os instrumentos necessários, pois de qualquer maneira ela está presente aqui e em todo lugar."

Michel Foucault 
Dou Graças a Deus por tudo e agradeço, de coração, à minha família 


\section{Agradecimentos}

À minha orientadora Prof ${ }^{\mathrm{a}} \mathrm{Dr}^{\mathrm{a}}$ Vitória Kedy Cornetta, que mais uma vez com sua incansável disposição, me apoiou, incentivou e tranquilizou.

Aos Lefèvre, Prof. Dr. Fernando e $\mathrm{Dr}^{\mathrm{a}}$ Ana Maria, mestres em todas as horas.

A todos os meus colegas do Serviço de Biblioteca e Documentação da Faculdade de Medicina da Universidade de São Paulo, companheiros do trabalho diário.

À minha amiga Izabel Cristina Amaral Pereira, e seu apoio sempre e em tudo.

À Mariza Leal de Meirelles do Coutto, pelas conversas e esclarecimentos.

Ao Prof. Dr. Joel Cláudio Heimann, pelo incentivo recebido.

A todos os profissionais, meus colegas das equipes das bibliotecas, que se dispuseram a participar das entrevistas para a elaboração deste trabalho. 
RESUMO

ABStRACT

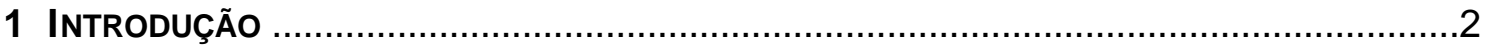

2 SAÚDE PÚBLICA, CIÊNCIA DA INFORMAÇÃO E BIBLIOTECONOMIA....................................

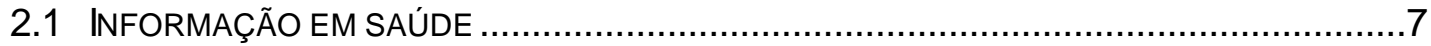

2.2 CIÊNCIA DA INFORMAÇÃO E BIBLIOTECONOMIA ...................................................12

2.3 OS BIBLIOTECÁRIOS - PROFISSIONAIS DA INFORMAÇÃO ........................................17

3 A QuALIDAdE E SEUS ASPECTOS NA PRESTAÇÃo DE SERVIÇOS DE INFORMAÇÃo ..........24

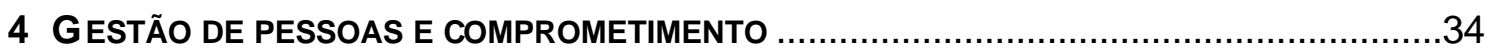

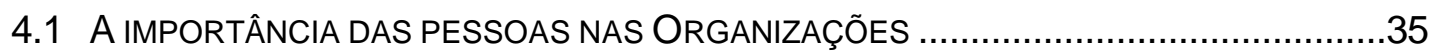

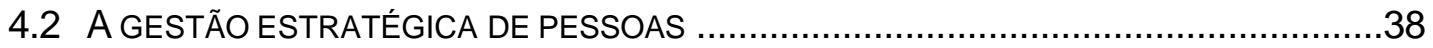

4.3 A BUSCA DO COMPROMETIMENTO ORGANIZACIONAL .........................................43

4.3.1 A PESQUISA SOBRE COMPROMETIMENTO ..............................................52

5 O Sistema InTEgRado de Bibliotecas da UniVERSIDAde de SÃo PAULO - SIBI/USP56

5.1 A AÇÕES DE CAPACITAÇÃO PARA O COMPROMETIMENTO

6 Justificativa

7 OBjetvos

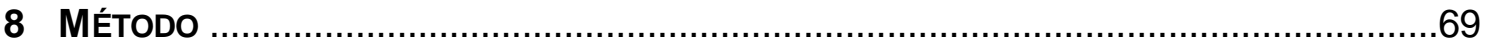

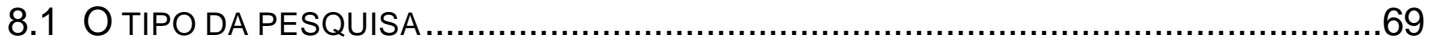

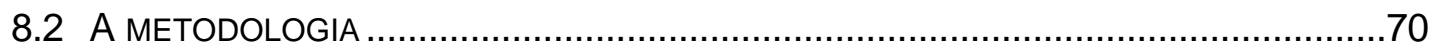

8.3 O UNIVERSO E A AMOSTRA DA PESQUISA ......................................................

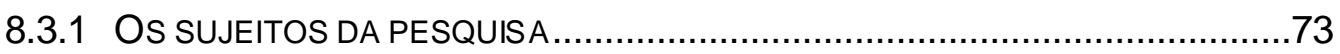

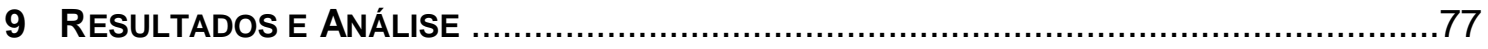

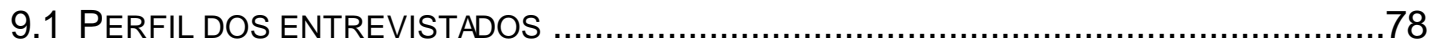

9.2 APRESENTAÇÃO E ANÁLISE DOS RESULTADOS QUALI-QUANTITATIVOS .....................81 


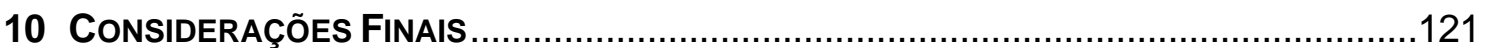

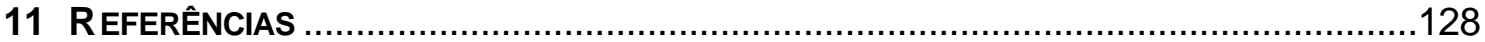

ANEXOS

I - TERMO DE CONSENTIMENTO LIVRE E ESCLARECIDO

II - ROTEIRO PARA AS ENTREVISTAS

III - RESUMO dE IDÉIAS CENTRAIS 
Crestana, MF. O comprometimento de pessoas de um Sistema de Bibliotecas Universitárias [tese de doutorado]. São Paulo: Faculdade de Saúde Pública da Universidade de São Paulo; 2006. 138p.

Aborda o desenvolvimento profissional e intelectual de equipes bibliotecárias, compostas por diferentes categorias profissionais e que atuam no contexto da tecnologia da informação, da globalização, do acesso à informação e das transformações sociais, e que, tendo qualificação profissional específica, devem ser objetos de contínua capacitação. No cenário de evolução dos modelos administrativos e da gestão de pessoas, aborda as ações de capacitação e desenvolvimento promovidas para essas equipes, pelo Departamento Técnico do Sistema Integrado de Bibliotecas da Universidade de São Paulo - DT/SIBi/USP, e em que medida essas ações de capacitação promovem o comprometimento das pessoas que compõem essas equipes, com as bibliotecas. Objetivo: identificar nos bibliotecários e profissionais de níveis técnico e básico das bibliotecas do SIBi/USP, na área de saúde, suas opiniões sobre comprometimento organizacional. Método: análise do material verbal colhido através de entrevistas feitas com os três grupos de profissionais, transcrito e tratado com a metodologia do Discurso do Sujeito Coletivo. Resultados: os resultados qualiquantitativos revelam o que pensam esses profissionais a respeito do tema e os discursos constituem material que poderá apoiar o Departamento Técnico do SIBi/USP a delinear e propor, a partir das suas diretrizes e políticas, as ações para o comprometimento e desenvolvimento das equipes do Sistema.

Descritores: Bibliotecas Médicas, recursos humanos. Administração de Recursos Humanos. Desenvolvimento de pessoal. 
Crestana, MF. The personnal commitment of a Academic Library System [tese de doutorado]. São Paulo: Faculdade de Saúde Pública da Universidade de São Paulo; 2006. 138p.

It approaches the professional and intellectual development of the librarians teams, which are composed by unlike professional classes, who perform on the context of technological information, about globalization, about the access to information and social transformations, so that to aiming a specific professional qualification, their purpose must be of continuous capability. In the evolution scenery of administrative patterns, as well as of human management, it approaches capability and evolution actions and development, promoted for those teams by the Technical Department of the Integrated System of the University of São Paulo Libraries (Departamento Técnico do Sistema Integrado de Bibliotecas da Universidade de São Paulo) - DT/SIBi/USP, and in which proportion these capability actions promote the committment of all the persons who compose these teams towards libraries. Purpose: to identify among librarians and professionals of technical level and basic level of the SIBi/USP libraries, in health area, their opinions about organizational pledge. Methodology: the analysis of the collected verbal material, throughout the interviews done, with the three professional groups, which has been transcribed and handled with the methodology of the Collective Citizen Speech (Discurso do Sujeito Coletivo). The results: the qualiquantitavive results bring out what these professionals think about the matter, and the speeches represent the material which might support the Technical Department of SIBi/USP (Departamento Técnico do SIBi/USP) to outline and propose, from their line of directions and policies, the actions for the committment and development of the system's teams.

Descriptors: Libraries, medical, manpower. Personnel Management. Staff Development 
1 Introdução 
Os desafios enfrentados pelas empresas de produção de bens ou serviços são de modo geral, reflexos das mudanças ocorridas na economia, nas relações sociais e políticas, na evolução da tecnologia, na organização da produção, nas relações de trabalho e na própria inserção do elemento humano no contexto social e produtivo.

As conseqüentes novas demandas surgidas desse novo cenário, representam por sua vez, a necessidade de mudanças de ordem tecnológica nos sistemas de gestão, especialmente no que se refere à gestão dos recursos humanos, ou gestão de pessoas, termo que tem sido cada vez mais adotado.

Mesmo a mais elaborada estratégia de negócio e o mais moderno aparato tecnológico não conseguem alavancar resultados positivos, sem que haja o engajamento dos seus colaboradores com as organizações, e conseqüentemente, com os seus resultados.

Prevendo esta nova realidade, já há algum tempo as escolas voltadas para negócios e para a área de gestão de pessoas, bem como as organizações, consultorias, técnicos e demais profissionais têm se ocupado com o tema do comprometimento de seus colaboradores.

Como relatado em HYPÓLITO, LINGUANOTTO, DE GRANDI, ROSETTO, SAMPAIO, DO COUTTO e TEIXEIRA (1999), a biblioteca é uma organização similar à empresa, quando intermedia a informação como insumo ou matéria prima, com as necessidades e expectativas dos clientes internos e externos, seus usuários, e produtos e serviços que determinam 
um fluxo a partir do mercado. As mesmas estratégias adotadas pelas empresas se ajustam à organização/biblioteca: padrões de qualidade nos produtos e nos serviços, manutenção da produtividade e competitividade, estabelecimento de parcerias com agregação de valor a ambas as partes e flexibilidade não só na articulação dos processos como no realinhamento com novas tendências ou para novas demandas.

As equipes bibliotecárias compostas por diferentes categorias funcionais e atuando no contexto da tecnologia da informação, da decantada globalização, do acesso à informação e das transformações sociais, além das exigências de qualificação profissional específica, devem ser objeto de contínua capacitação. Segundo BELLUZZO (1995, p. 20), “... visando à conscientização, motivação e desenvolvimento de habilidades de todas as pessoas envolvidas, em relação a uma nova filosofia operacional, de forma a assegurar que cada indivíduo venha a realizar suas atividades de maneira correta e eficaz."

Tratando-se de equipes bibliotecárias, com corpus específico de conhecimento e prática, é um campo de atividade favorável na busca do comprometimento de pessoas.

De acordo com ALBUQUERQUE (1999, p. 235),

“... alguns setores de atividade e ambientes são mais propícios do que outros, ao desenvolvimento de uma estratégia de comprometimento, ou sua aplicabilidade é mais evidente. É o caso, por exemplo, do setor de prestação de serviços técnicos especializados, que utiliza pessoas de alto nível de qualificação 
para as quais o desenvolvimento e o aprendizado contínuo são fundamentais."

No sentido de alcançar níveis desejáveis de qualidade na prestação de serviços, de acordo com as demandas do cliente e pari passu com o desempenho de qualidade pretendido pelas organizações em que se inserem, devem ser desenvolvidos programas de treinamento para as pessoas, com o envolvimento de todos e sempre com vistas ao comprometimento delas com os objetivos dessas organizações.

Nessas condições pesquisadores e estudiosos tem estudado o comprometimento dos empregados com os seus trabalhos, desde a década de 80, para compreender as principais variáveis que explicam 0 comportamento humano frente ao trabalho, valendo-se das diversas abordagens conceituais e fontes teóricas.

As bibliotecas, assim como as empresas necessitam de colaboradores altamente motivados, focados nas exigências do cliente, na execução da estratégia e na capacidade de "entregar" estas exigências.

Tudo isso somente poderá ser apurado utilizando recursos/instrumentos capazes de fornecer um diagnóstico correto da situação, identificando os diferentes níveis de comprometimento, para então estabelecer diretrizes de aprimoramento.

Compreender portanto, o que pensam a respeito do tema Comprometimento organizacional e suas implicações no trabalho desenvolvido pelas equipes bibliotecárias, torna-se um dado importante para 
a gestão de pessoas no âmbito das bibliotecas do Sistema Integrado de Bibliotecas da Universidade de São Paulo - SIBi/USP.

Cabe ressaltar que o Departamento Técnico do SIBi/USP, como outras Unidades da Universidade de São Paulo, aderiu ao Programa de Qualidade e Produtividade da USP, e o desdobramento dessa adesão está presente em todas a outras ações ocorridas no Sistema, no sentido de buscar padrões de qualidade no desempenho e resultados das atividades exercidas nas suas bibliotecas, bem como de investimentos na capacitação e qualidade de vida de suas equipes profissionais.

Essa pesquisa volta-se portanto, para o universo das bibliotecas do Sistema que fazem parte da área de ciências biológicas, no trato da saúde humana, e que direta ou indiretamente, de forma essencial ou complementar são orgãos de apoio às atividades de ensino e pesquisa da Universidade e onde alunos e pesquisadores da saúde pública ou das ciências da saúde buscam informações, incorporadas as abrangências e os delineamentos do que se entende por saúde:

“... desde há alguns anos a nossa visão de saúde passou da mera ausência da doença para a noção de bem-estar físico e mental, e daí para conceito mais amplo que inclui uma adequação de vida social. Ocorre claramente uma mudança de paradigma, inclusive com ruptura semântica entre o conceito atual de saúde e o anterior. Modifica-se a prática sanitária, passando-se da antiga curativista - para a atual - a vigilância da saúde. Retomando a exposição inicial, o Brasil vive hoje a experiência inédita da implementação, na prática, dessa revolução teórica. (SANTOS e WESTPHAL, 1999, p. 72) 


\section{Saúde pública, ciência da informação e Biblioteconomia}




\subsection{INFORMAÇÃO EM SAÚDE}

A exemplo das organizações de prestação de serviços, as instituições de saúde, incluindo os órgãos de planejamento, gerenciamento e assistência à saúde e as atividades educacionais, necessitam contar com informações de natureza variada, além das informações tradicionalmente ofertadas pelos sistemas de bibliotecas universitárias especializadas ou centros de informação.

DIAS e BELLUZZO (2003), apresentam um diagrama do contexto da informação nas organizações, o qual pode ser adaptado para o contexto das atividades inerentes à saúde das populações.

\begin{tabular}{|c|c|c|c|}
\hline \multicolumn{4}{|c|}{ A informação nas Unidades de Ensino e Pesquisa } \\
\hline Classificação & Dimensões & Objetivos & Fontes \\
\hline $\begin{array}{l}\text { Quanto à Natureza } \\
\text { Informação Científica: } \\
\text { Resultante das atividades } \\
\text { de pesquisas científicas e } \\
\text { literatura na área } \\
\text { Informação de Negócios: } \\
\text { Resultante da prestação de } \\
\text { Serviços } \\
\text { Quanto à função } \\
\text { Informação acadêmica: } \\
\text { Para o ensino, a pesquisa e } \\
\text { a extensão } \\
\text { Informação estratégica: } \\
\text { Relacionada aos processos } \\
\text { de gestão }\end{array}$ & $\begin{array}{l}\text { Formato } \\
\text { - Impressa e/ou eletrônica } \\
\text { - Texto e/ou audio-visual e/ou } \\
\text { multimídia } \\
\text { Local } \\
\text { - Interna e/ou externa } \\
\text { Nível } \\
\text { - Bruta e/ou organizada e/ou } \\
\text { tratada e/ou avançada } \\
\text { Status } \\
\text { - Publicada e/ou de divulgação } \\
\text { - Pessoal e/ou pública } \\
\text { Cliente } \\
\text { - Interno e/ou externo }\end{array}$ & $\begin{array}{l}\text { Ensino, Pesquisa e } \\
\text { Extensão } \\
-\quad \text { Apoio das } \\
\text { desenvolvimento didático- } \\
\text { atividades da extensão } \\
\text { científicas } \\
\text { - Propósitos da } \\
\text { e pesquisa } \\
\\
\text { Gestão } \\
\text { - Processos } \\
\text { - Serviços } \\
\text { - RH }\end{array}$ & $\begin{array}{l}\text { - Literatura científica } \\
\text { - Bases e bancos de } \\
\text { dados } \\
\text { - Normas técnicas e } \\
\text { patentes } \\
\text { - Manuais } \\
\text { - Diretórios de } \\
\text { instituições, especialistas } \\
\text { e eventos } \\
\text { - Regulamentações e } \\
\text { legislação } \\
\text { - Serviços de informação, } \\
\text { bibliotecas e centros de } \\
\text { documentação }\end{array}$ \\
\hline
\end{tabular}

Adaptado de DIAS, Maria Matilde Kronka. O gerenciamento de unidades de informação tecnológica sob enfoque da qualidade: do estudo das percepções e reações do cliente ao desenho de novas condutas. 2001. Tese (Doutorado) - Escola de Comunicações e Artes, Universidade de São Paulo, São Paulo, 2001. 
Segundo CARVALHO (1998), as ações de planejamento, organização e administração das ações em saúde, incorporam em suas teorias as noções de sistemas de informação, que implicam na interação entre os componentes da realidade que deverá ser captada por eles, buscando a recomposição de um todo, mediante o conhecimento e a comunicação.

Esses sistemas de informação em saúde, congregam ainda informações sobre indicadores sociais relevantes para a prestação e o consumo de serviços de saúde, que no Brasil estão nos diversos sistemas de informação (SIS) do país, sob responsabilidade do Departamento de Informática do SUS (DATASUS), do Centro Nacional de Epidemiologia (Cenepi) e da Fundação Nacional de Saúde (Funasa), todos orgãos do Ministério da Saúde.

Estatísticas vitais são fornecidas pelo Sistema de Informações de Mortalidade (SIM), desde 1979 e pelo Sistema de Informações de Nascidos Vivos (Sinasc) desde 1944. Doenças de notificação compulsória são registradas de maneira estruturada, desde 1995, no Sistema de Notificação de Agravos (SINAM).

No nível federal esses mesmos dados estão no Boletim Epidemiológico do SUS.

O Sistema de Informações Hospitalares (SIH-SUS) contém dados sobre internações hospitalares e o Sistema de Informações Ambulatoriais (SAI-SUS). 
O Sistema de Informação de Atenção Básica (Siab) subsidia municípios, estados e federação com informações desenvolvidas no Programa de Agentes Comunitários de Saúde (Pacs) e do Programa de Saúde da Família (PSF).

Dados de pesquisas e censos da Fundação Instituto Brasileiro de Geografia e Estatística (IBGE) são também usados em saúde, como o Censo Demográfico e Contagem de População e a Pesquisa Nacional por Amostra de Domicílios - PNAD. (TRAVASSOS, SANTOS, SZWARCWALD, BARCELLOS, ROMERO, BASTOS, VIACAVA e AZEVEDO, 2000)

As informações em saúde, estão ainda nas unidades de informação ligadas aos órgãos e instituições do setores públicos e privados da área de saúde, além das unidades de ensino e pesquisa, nas suas bibliotecas e centros de documentação e podem ser acessadas, tradicionalmente, nos locais em que se encontram os acervos ou remotamente, quando estão organizadas em portais eletrônicos e o acesso é online.

No âmbito brasileiro, da América Latina e do Caribe, no que se refere à pesquisa em saúde, a convergência das tendências do processo de produção e de utilização do conhecimento produzido se dá pela criação de plataformas e espaços, que permitem a interação dos atores de ambos os processos. A Biblioteca Virtual em Saúde (BVS) da BIREME/OPS é um exemplo disso, ao permitir o acesso universal em tempo real aos produtores, intermediários e usuários das redes de colaboração e de intercâmbio das informações em saúde. 
As principais fontes de informação nela contidas são:

- SCAD - Serviço corporativo de acesso a documentos em formato eletrônico

- Catálogos de Publicações

- Bases de dados bibliográficas

- Serviço de disseminação seletiva da informação

- Publicações Eletrônicas - SciELO (Scientific Electronic Library Online)

- Diretórios de instituições e eventos

- Informações para apoio aos processos de tomada de decisão

- Informações de apoio a cursos

- Localizador de Informações em Saúde (LIS)

Também da OPS, o Decides - Democratizando o conhecimento e a Informação para o Direito à Saúde, com a cooperação técnica através das novas tecnologias de comunicação e informação, propicia a produção, disseminação e utilização da informação em saúde, com três componentes básicos:

- Agenda Interativa de Investigação em Saúde (Agenda)

- Rede de Intercâmbio de Investigadores (Rediisal)

- Cidades Solidárias (Cisol)

Além das informações de caráter epidemiológico e daquelas geradas na assistência à saúde, há a informação acadêmica, utilizada para a geração do conhecimento necessário à formação acadêmica em saúde, em todas as categorias profissionais da área da saúde e que de modo geral, está nos acervos das instituições de ensino de graduação e pós-graduação. 
São os acervos das bibliotecas especializadas, formados e tratados especialmente para dar suporte às atividades de ensino e pesquisa; no caso da Universidade devem ainda contemplar as atividades de extensão dirigidas à comunidade.

Esses acervos são formados a partir das necessidades informacionais das disciplinas, suas bibliografias básicas e recomendadas, das linhas de pesquisa e especialidades de cada uma dessas unidades de ensino e pesquisa.

Essas bibliotecas especializadas são assim definidas por RAVE, URIBE e PÉREZ (2001, p. 12),

“... se caracteriza no solamente porque cubre un área del conocimiento específica sino por el tipo de usuario que atiende, el cual es tambiénespecífico, con necesidades muy puntuales y por lo tanto los servicios que ofrecen son especializados, personalizados, cuidadosamente dirigidos a atender sus necesidades alderedor a sus funciones relacionadas com la investigación, la toma decisiones y el soporte administrativo, la información que ofrece es de alta calidad. Su misión es adelantarse a las necesidades del usuario, sus funciones son del tipo tecnico, informativo y administrativo con objetivos concretos que son definidos por la institución a que pertenese." 


\subsection{CIÊNCIA DA INFORMAÇÃO E BIBLIOTECONOMIA}

O conceito guarda estreitas relações com o fenômeno denominado "explosão da informação" ocorrido logo após a 2ª Grande Guerra e do esforço do "controle bibliográfico" e de tratamento da documentação implícita no processo.

O surgimento da Ciência da Informação estaria relacionado com a atividade subsequente ao controle da produção científica e à regularidade do fenômeno relativo à sua dispersão e uso, obsolescência, epidemiologia de propagação e outros aspectos do processo de manipulação e análise da literatura.

MIRANDA (2003, p. 93) aborda a importância da definição da palavra informação e vale-se de Wersig e Neveling (1975), para afirmar que,

“... a Ciência da Informação, a julgar por sua origem programática, tem menos a ver com informação e mais com documentação"; complementando que embora o conteúdo informacional dos documentos seria objeto de análise de cada ciência a ele relacionada, “... o documento em si, enquanto registro, requer abordagens próprias, dentre elas a da Ciência da Informação que o toma como fenômeno independente.

GALVÃO e BORGES (2000, p. 48) contextualizam esse ambiente de proliferação da informação e de produção do conhecimento, com base nos textos do Programa Sociedade da Informação, do Ministério da Ciência e Tecnologia (2000), e afirmam que nessa sociedade, comunicação e 
informação permeiam as atividades e processos nas diferentes esferas da sociedade, que passam progressivamente, a funcionar em rede.

Além disso, abordam o papel das instituições ligadas ao ensino, à pesquisa, à tecnologia e à saúde, para a geração e comunicação do conhecimento e a promoção da educação e da saúde, para a melhoria da qualidade de vida das comunidades e concluem:

“... A ciência da informação se caracteriza pelo estudo da informação, pelo relacionamento com várias ciências e insere-se no contexto da sociedade, tendo aqui o profissional da informação um papel importante e necessário."

A informação como objeto de estudo da Ciência da Informação é assim definida por SMIT e BARRETO (2002, p. 18):

“... estruturas simbolicamente significantes, codificadas de forma socialmente decodificável e registradas (para garantir permanência no tempo e portabilidade no espaço) e que apresentam a competência de gerar conhecimento para o indivíduo e para o seu meio. Estas estruturas significantes são estocadas em função de um uso futuro, causando a institucionalização da informação."

Os autores acrescentam que a formação do profissional que vai lidar com essa informação incorpora técnicas e procedimentos da Biblioteconomia, acrescidos dos aspectos de trato dessa informação e da compreensão de suas origens e finalidades sociais. 
OLIVEIRA e ARAUJO (2002, p. 38) recorrem aos estudos de Francis Miksa (1991) ao discorrerem sobre os diferentes paradigmas de Ciência da Informação e Biblioteconomia e afirmam que 0 ponto focal da Biblioteconomia é a própria biblioteca, como uma instituição social e como tal, com material organizacional e características que expressam suas funções em uma estrutura social, incluindo suas propriedades materiais, organizacionais e intelectuais que viabilizam sua função mediadora entre os indivíduos e o conhecimento que eles necessitam: “... importante organização social dentre as demais instituições associadas com o processo de transferência de conhecimento."

Segundo o mesmo autor o paradigma da Ciência da Informação refere-se às idéias relativas ao processo, que tem como fenômeno central o movimento da informação em um sistema de comunicação humana, paradigma que tem inclusive, influenciado a Biblioteconomia, não só por conta da palavra informação mas também de um conjunto de outros termos que caracterizam as atividades dessa área.

Antecederam a ciência da informação, a documentação e a recuperação da informação e o grande desafio passou a ser de recuperar por especialidade, grandes massas de documentos produzidos, principalmente a partir de 1945, utilizando novas tecnologias de organização e disseminação da informação.

Para LE COADIC (1996, p. 7) que trata a informação como “... um conhecimento inscrito (gravado) sob forma escrita (impressa), oral ou audiovisual..." a Ciência da informação "... tem por objeto o estudo das 
propriedades gerais da informação (natureza, gêneses e efeitos), mas sejam quais forem os conceitos adotados, o certo é que ela surge numa sociedade que atribui à informação, novos paradigmas, sempre relacionados ao desenvolvimento científico e tecnológico.

A Ciência da informação desenvolveu-se no Brasil, mais do que nos países desenvolvidos, imbricada com a biblioteconomia, mesmo sendo orientadas por paradigmas diferentes; em alguns momentos e situações "... é possível observar conflitos dessas duas áreas em outros compartilhamento e cooperação."(LE COADIC, 1996, p. 45)

A formalização do curso de Ciência da informação foi no ano de 1972 pelo antigo Instituto Brasileiro de Bibliografia e Documentação - IBBD, hoje denominado Instituto Brasileiro de Informação em Ciência e Tecnologia IBICT, com o primeiro curso de pós-graduação dessa área e a partir disso outras instituições como a Escola de Comunicação e Arte da Universidade de São Paulo - ECA-USP, a Universidade Federal de Minas Gerais UFMG, a Pontifícia Universidade Católica de Campinas - PUCCAMP, a Universidade Federal da Paraíba - UFPB e a Universidade de Brasília UnB também tiveram seus programas de mestrado ou doutorado. Neste mesmo ano teve início a edição de duas revistas da área: Revista Brasileira de Biblioteconomia e Documentação e a Revista Ciência da Informação.

MARCHIORI (2002, p. 61) resume um recorte da Ciência da Informação,

“... ocupa-se do estudo da informação em si, isto é, a teoria e a prática que envolve sua criação, identificação, coleta, validação, 
representação, recuperação e uso, tendo como princípio o fato de que existe um produtor/consumidor de informação que busca, nesta, um sentido e uma finalidade."

No Brasil, a Biblioteconomia ao lado dos cursos de Arquivologia e Museologia, é um dos cursos da Ciência da Informação, na carreira de Ciências Sociais Aplicadas, de acordo com critério Capes - Coordenação de Aperfeiçoamento de Pessoal de Nível Superior, pelo estabelecimento de Diretrizes Curriculares, Resolução CNE/CES 19, de 13 de março de 2002 (DOU 9 abr 2002).

É nesse contexto que atuam os bibliotecários, no campo que, de acordo com as Diretrizes,

“... abarca todos os fenômenos ligados à produção, organização, difusão e utilização de informações...", tendo como objeto "... a informação registrada, acatadas as respectivas formas de vê-la, processá-la e utiliza-la, consoante diferentes tradições e marcos teóricos e, como disciplinas instituidoras de ambientes de mediação entre acervos (estoques informacionais) e necessidades do usuário."

MIRANDA (2003, p. 177) ao abordar o tratamento da produção intelectual afirma, que uma vez produzido, o texto é público, sujeito a críticas, apropriações e reformulações, até mesmo por quem o produziu, e refere-se aos bibliotecários e sua atividades de trabalho:

“... sempre coisificaram seus acervos, criando medidas e parâmetros relativos às suas propriedades físicas que permitem a 
sua seleção, aquisição, tratamento técnico, armazenamento, o uso, sua propagação por diferentes tipos de mídia, etc. Informação no sentido tangível, mensurável, deteriorável física e intrinsecamente, com volume, peso, preço e outras propriedades administráveis."

A despeito dos debates e estudos que buscam diferenciar e identificar os bibliotecários e sua prática profissional com relação a outros profissionais, por vezes chamados de profissionais da informação, categoria que inclui várias outras formações acadêmicas, ou os documentalistas, é necessário que se estabeleça o que significa a formação do profissional bibliotecário.

\subsection{OS BIBLIOTECÁRIOS - PROFISSIONAIS DA INFORMAÇÃO}

LOUREIRO e JANNUZZI (2005, p. 132) consideram que o conceito de profissional da informação encontra-se ainda em construção; tendo estudado opiniões de um grande número de autores a respeito das diferenças e dos pontos comuns entre esses profissionais, os documentalistas e os bibliotecários, as autoras pontuam as diversas fases pelas quais passou a profissão bibliotecária,

“ Destaca-se.o registro da informação como ponto fundamental para o nascimento das profissões ligadas à organização e à difusão de informações”... “... a profissão de bibliotecário, se formou inicialmente pautada em largo conhecimento cultural e humanístico, passando até a ser considerada elitista, devido ao grande conhecimento e erudição de seus profissionais, para 
depois mergulhar na técnica, perdendo sua visão crítica...”... Com o advento das TIC (tecnologias de informação e comunicação), a categoria resolveu assimilar o ambiente virtual como campo de trabalho..."

No mesmo estudo é citado o papel social do bibliotecário para uma das funções mais recentes a ele atribuídas, a information literacy, ou um dos seus aspectos, a alfabetização em informação como refere-se a autora.

..."a tarefa de promover a formação de uma cultura informacional na sociedade, ajudando-a a melhor utilizar as informações e, nesse sentido, conseguir que ela ingresse na Era da Informação e do Conhecimento com uma visão mais crítica e com mais bagagem, para resolver problemas ou tomar decisões."..."a info-alfabetização é uma parte dessa alfabetização em informação, em que as pessoas aprendem a usar o computador e acessar as informações desejadas, sempre com uma reflexão crítica sobre elas. Como principal característica o profissional da informação é o mediador entre o mundo digital e a capacidade real de entendimento do receptor da informação, garantindo a efetiva comunicação e a satisfação da necessidade informacional do usuário dessa tecnologia." (TARAPANOFF, SUAIDEN e OLIVEIRA, 2004, p. 4)

Para ALMEIDA JUNIOR (2000, p. 42) profissional da informação é um termo, ou ainda uma designação não específica do bibliotecário, mas que abrange um vasto grupo de outros profissionais que atuam em áreas que 
têm como base a informação em “... seus vários aspectos, abordagens, suportes e momentos."

A formação dos profissionais bibliotecários, no Brasil, teve duas linhas de influência, uma humanista, pela École Nationale des Chartres, fundada em 1821, na cidade de Paris e outra de caráter mais tecnicista, vinda dos Estados Unidos, pela fundação da School of Library Economy, por Melvill Dewey, na Columbia University de New York, em 1887; prevaleceu no entanto, o modelo norteamericano.

A regulamentação da profissão é assegurada pela lei 4.084 promulgada em 30 de junho de 1962, regulamentada pelo Decreto n 56.725 de 16 de agosto de 1965.

A fiscalização do exercício da profissão “... fica a cargo do Conselho Federal de Biblioteconomia, com sede no Distrito Federal e dos Conselhos Regionais de Biblioteconomia..." (CONSELHO REGIONAL DE BIBLIOTECONOMIA 8를 REGIÃO, p.6)

No documento que normaliza o reconhecimento, a nomeação e a codificação dos títulos e conteúdos das ocupações do mercado de trabalho brasileiro, a Classificação Brasileira de Ocupações - CBO, o título Bibliotecário, encontra-se na família de ocupações denominadas Profissionais da informação, de n 2612, e são apontados sinônimos dessa ocupação: bibliográfo, biblioteconomista, cientista da informação, consultor de informação, especialista de informação, gerente de informação, gestor de informação. 
A descrição sumária refere-se a

“... Disponibilizam informação em qualquer suporte; gerenciam unidades como bibliotecas, centros de documentação, centros de informação e correlatos, além de redes e sistemas de informação. Tratam tecnicamente e desenvolvem recursos informacionais; disseminam informação com o objetivo de facilitar o acesso e a geração do conhecimento; desenvolvem estudos e pesquisas; realizam difusão cultural; desenvolvem ações educativas. Podem prestar serviços de assessoria e consultoria." (http://www.mtecbo.gov.br/busca/descricao.asp)

Acrescenta também, que o exercício dessas ocupações requer o grau de bacharelado em Biblioteconomia e Documentação.

Para a categoria dos técnicos em biblioteconomia, família de ocupações no 3711, a CBO identifica como sinônimos: técnico de biblioteca, técnico de documentação e informação, técnico em documentação, tratador de documentos. Para o exercício da profissão é apontada a obrigatoriedade da formação técnica em biblioteconomia em nível médio e entre quatro e cinco anos de experiência para o exercício pleno das atividades.

Independente da escola de formação profissional dos bibliotecários, algumas habilidades e competências são consensuais e ponto de partida para discussões e propostas de perfis ideais desse profissional. Dentre elas está a citada por VALENTIM (2002, p. 122), extraída e traduzida do documento final Programa, da Reunião de Diretores do IV Encuentro de 
Directores de Escuelas de Bibliotecologia y Ciência de la Información del Mercosur, realizado em Montevideo, em 2000:

"Por competências profissionais se entende o conjunto de habilidades, destrezas, atitudes e de conhecimentos teóricopráticos necessários para cumprir uma função especializada de um modo socialmente reconhecível e aceitável. Em suma, as competências profissionais compreendem 0 conjunto de habilidades, destrezas e conhecimentos que um profissional de qualquer área do conhecimento humano precisa contar, para cumprir as atividades especializadas, oferecendo o mínimo de garantia sobre os resultados de seu trabalho, tanto em relação ao seu público, quanto em relação ao seu empregador, em última instância, a sociedade da qual faz parte."

A formação do profissional bibliotecário, estudada por ARRUDA, MARTELETO e SOUZA (2000, p. 17), é vista como um grupo cuja atuação profissional vem sofrendo transformações, e aborda as discussões em torno das qualificações necessárias para que o bibliotecário interaja como sujeito diante dos novos requerimentos do mundo do trabalho: novos ambientes de trabalho, inovações tecnológicas e exigências do mercado, apontando para a importância da educação continuada e para a ampliação das competências pessoais. "... um novo perfil profissional que requer, além de maior qualificação profissional, maior envolvimento emocional e social do trabalhador." 
Elege-se como ideal o profissional que potencialize a comunicação, a interpretação de dados, a flexibilização, a integração funcional e a geração, absorção e troca de conhecimento,

"Os indivíduos interagem em grupos, mas não são parceiros do grupo, e sim da organização, comprometidos com sua visão estratégica e sua missão organizacional. "( MACHADO, 1996, p. 175)

De acordo com CASTRO (2002, p. 192) a formação delineada como ideal prevê no entanto, que além da habilitação pela graduação e/ou pósgraduação, que esses profissionais continuem a desenvolver capacidades e construir competências, para uma formação profissional que,

“...vise ao universo do trabalho [e a não somente ele], tal como hoje se configura, deve situar no foco das atenções algo que não é novo, que sempre existiu, mas que produzia seus efeitos de modo coadjuvante ou colateral: as competências básicas a serem desenvolvidas dizem respeito à formação pessoal, às capacidades pessoais, que transcendem os temas estudados, que sobrevivem às transformações cada vez mais rápidas nos cenários dos equipamentos e da produção material." 
3 A qualidade e seus aspectos na prestação de serviços de informação 
No ambiente de mudanças em que vivemos, na busca de soluções gerenciais e alternativas de incentivo à produção e à prestação de serviço, as organizações têm voltado seus olhares para as questões que apontam e valorizam a satisfação de seus clientes internos e externos e lançam mão das mais diversas ferramentas, técnicas e programas para alcançar qualidade e produtividade, que de acordo com FLEURY (1993) têm como pontos comuns, as estratégias organizacionais voltadas para as necessidades dos clientes.

$\mathrm{Na}$ busca pela Qualidade, como preocupação que permeia o desenvolvimento de produtos e serviços, principalmente a partir de meados de 1945, com o término da 2ª Guerra Mundial, o americano William Edwards Deming apresenta sua filosofia, composta de catorze pontos, que iniciaram, por assim dizer, a era da qualidade; DEMING (1990, p. 18):

“1. Estabelecer a constância de propósitos para melhoria do produto;

2. Adotar a nova filosofia;

3. Cessar a dependência da inspeção em massa;

4. Acabar com a prática de avaliar os orçamentos apenas com base no preço;

5. Melhorar constantemente os sistemas de produção e serviços;

6. Instituir o treinamento e o retreinamento;

7. Adotar e instituir a liderança;

8. Afastar o medo;

9. Romper as barreiras entre os diversos setores de pessoal; 
10.Eliminar slogans, exortações e metas para a mão-de-obra;

11.Eliminar as cotas numéricas para a mão-de-obra;

12. Remover as barreiras ao orgulho da execução;

13. Instituir um sólido programa de educação e re-treinamento;

14. Agir no sentido de concretizar a transformação."

Para BELLUZZO e MACEDO (1993), a filosofia de Deming e seus 14 princípios são passíveis de adaptação e adoção pelas bibliotecas universitárias; a mesma opinião, foi expressa por BARBALHO (1996) ao analisar a atuação das unidades de informação no cenário nacional e internacional.

PINHEIRO e COSTA (2005) analisam o método na administração e sua aplicabilidade no trabalho informacional, com vistas à otimização nos resultados e ao melhor desempenho na produção de serviços e produtos, gerados nas bibliotecas universitárias; afirmam que é possível absorver e cultivar a filosofia de Deming, desenvolvendo criatividade e capacidade para acertar os caminhos que levam à excelência do trabalho informacional. Ressaltam que sua implantação deve observar algumas questões básicas, como:

a) todos devem estar envolvidos e acreditar na mudança;

b) é preciso que os profissionais da informação saibam gerenciar, sem perder de vista a import6ancia das relações humanas, na organização;

c) que o usuário é a fonte de toda avalização sobre a qualidade dos produtos e serviços; 
d) que exista um feedback de informações e as metas da qualidade sejam claramente definidas;

Atendidas essas observações, as autoras acreditam ser possível utilizar aspectos do método como aliado no combate às barreiras que impedem a modernização da unidade de informação e sua gestão.

PINTO (1993) ao propor elementos para a qualidade dos produtos e serviços em centros de informação no Brasil, refere-se a essas instituições, como dotadas, da mesma forma que as bibliotecas, de uma estrutura organizacional, com o equivalente a divisões, departamentos e seções responsáveis pelas fases que antecedem a sua implantação, até a disponibilização das informações aos seus usuários, e ressaltam a importância dos seus recursos humanos como fundamentais, para a oferta de informação de qualidade.

Geralmente a implementação desses processos de qualidade têm o intuito de reorganizar a empresa, alterar o comportamento das pessoas, quebrar paradigmas e aumentar o nível de comprometimento organizacional, com a possibilidade de conseguir, desse modo, a mudança na cultura organizacional.

Em 1957, Armand V. Feigenbaum, publicou artigo sobre o controle da qualidade, de conformações mais abrangentes, como um sistema eficiente para a integração do desenvolvimento e manutenção da qualidade e dos esforços de melhoramento de qualidade dos diversos grupos em uma organização, propiciando a produção de bens e serviços em níveis mais 
econômicos, e levando em conta a satisfação total do consumidor. Estava assim Iançado o Total Quality Control, ou Controle da Qualidade Total, com vistas a propiciar satisfação ao cliente, gerando produtos e serviços por meio de ações organizadas de forma econômica, com assistência ao usuário, e com a participação de todos os empregados da organização participando e contribuindo para o esforço de desenvolvimento, manutenção e melhoria da qualidade de forma global. (DIAS, 2001).

No Japão, o Controle da Qualidade Total teve sua aplicação de forma descentralizada, ampliando a preocupação com a qualidade para todos os níveis executivos e operacionais das empresas. Mas embora assumisse como princípios básicos, a orientação pelo cliente, a qualidade em primeiro lugar, as ações orientadas por fatos e dados, o controle dos processos e o respeito pelos empregados, não incorporava nenhuma metodologia para medir e desenvolver a satisfação, a motivação e o envolvimento e comprometimento no trabalho.

Foi Peter Drucker, quando publicou "A prática da administração de empresas", nos anos 50, que delineou os princípios da Administração por Objetivos, modelo que orienta a empresa a preocupar-se mais com as atividades que devem ser desenvolvidas para que os fins propostos sejam atingidos.

Esse autor refere-se às mudanças ambientais, à definição dos objetivos, à criação de oportunidades, ao desenvolvimento pessoal, à descentralização administrativa, à multiplicidade de objetivos, ao autocontrole e à autoridade e liderança. 
No Brasil, a Qualidade começou a ser difundida nas décadas de 70 e 80, com a aplicação do Círculo de Controle da Qualidade - CCQ, trazido pelas empresas multinacionais em operação; evoluiu, ainda que pela aplicação de ferramentas ou instrumentos com a finalidade de organizar os sistemas de produção, mas ao mesmo tempo relacionada com a competitividade na indústria e nos serviços, propiciando,

“... uma nova forma de se relacionar, e que somente através da participação ativa de cada um dos funcionários, e pela somatória desses esforços, se consegue trabalhar diferentemente uma atividade, ou um conjunto de tarefas. Além do aprendizado técnico necessário quando se busca a normalização de certas atividades da empresa, os funcionários necessitam reconhecer os novos conceitos implícitos nessa nova sistemática, precisam desenvolver confiança, nessa nova visão do trabalho, estarem prédispostos às mudanças provenientes dessa nova visão e concepção para a realização do trabalho."(PAULINO, 2000, p. 202)

No contexto das bibliotecas, como organizações que oferecem serviços ou produtos de informação, cabem as ponderações de LE COADIC (1996) sobre como podem ser avaliadas quanto ao atendimento de seus clientes, em termos da qualidade, que é determinada pela interação do serviço com o cliente e pela capacidade que o serviço tem em responder às necessidades desse cliente e do valor, que é a estimativa do cliente em relação à capacidade global de satisfação das suas necessidades, por determinado produto. Essa avaliação tem dois enfoques: a relevância e 
confiabilidade da informação fornecida e o seu impacto para os clientes, na precisão e nos efeitos resultantes do uso dessas informações nas atividades desses clientes ou usuários.

Ainda que não sejam utilizados na sua totalidade, os modelos de gestão com foco na qualidade têm fornecido ferramentas, que tem sido utilizadas pelas bibliotecas, de forma pontual e indicam a preocupação genuína com os padrões de qualidade no intuito de oferecer serviços com a qualidade esperada por seus usuários.

“ O gestor empreendedor de uma unidade de informação deve conceber uma idéia global dos seus mercados, dos seus clientes e fornecedores, das práticas comerciais, dos hábitos e costumes que formam a cultura na qual está inserido o seu negócio e também como seu negócio é ofertado pelo restante da sociedade. "(RAMOS, 1995, p 37)

NASCIMENTO, TROMPIERI e BARROS (2005, p. 240) ao estudar a preocupação com a qualidade, por parte dos gerentes de serviços e unidades de informação, afirmam haver uma tendência na sociedade atual, para a valorização do papel do usuário como elemento principal na avaliação e uso de produtos e serviços, tendência que também tem sido adotada pelos gerentes que pretendem fazer a gestão da qualidade em suas bibliotecas ou unidades de informação,

"A qualidade em serviços de informação é de valor agregado ao produto, em face do problema de valorização, isto é, da visualização da expressividade do usuário satisfeito ou não com o serviço oferecido ou com a informação obtida. Isto reforça o 
princípio de que a satisfação do usuário é o ponto mais destacado nos programas de busca de qualidade em serviços."

Neste contexto de busca da qualidade, os autores referem-se a "uma cíclica e re-adaptação dos recursos humanos às novas mudanças e evolução da sociedade, facilitando constantemente o melhor atendimento aos usuários."

DIAS e BELLUZZO (2003, p. 164), sintetizam as qualidades do gestor nesse ambiente,

“... manter-se atento às necessidades dos clientes significa criar facilidades para uma comunicação permanente, personalizar a relação organização/cliente, transmitir ao cliente toda informação privilegiada que possa aumentar sua relação de confiança e, acima de tudo, significa tratar o cliente com respeito e profissionalismo, inserindo-se a ética como um dos principais valores desse relacionamento em ambientes informacionais, diminuindo o distanciamento entre os sujeitos e a informação. "

As exigências colocadas aos recursos humanos no ambiente da qualidade, têm merecido investimento por parte da maioria das organizações, que reconhecem que seu capital intelectual, deve ser gerido de forma sistemática e com investimentos que promovam ou enfatizem novas habilidades e competências: a combinação de conhecimentos, do saber-fazer, de experiências e de comportamentos utilizados no desempenho profissional. 
FARIA, OLIVEIRA, FORNER e D'ASTUTO (2005, p. 31) analisam as competências do profissional da informação em comparação com as características e descrições da Classificação Brasileira de Ocupações para o universo das profissões da informação, e a despeito de não haver consenso na literatura, em relação ao conceito de profissional da informação, esses autores apontam para organização e suas estratégias para a gestão de pessoas,

"Diante das transformações nas estratégias organizacionais decorrentes dos processos de globalização e convergências dos meios de comunicação, o principal input dos trabalhadores passou a ser a capacidade de criar, aprender e desenvolver novos conceitos, produtos e serviços baseados no conhecimento O imperativo de se inserir nessa dinâmica induz o profissional da informação a buscar alinhamento de suas competências e seus respectivos desempenhos aos paradigmas em pauta."

Segundo DIAS e BELLUZZO(2003), na dinâmica da prestação de serviços de informação e da satisfação das necessidades e expectativas do usuário, cabe ao gestor a motivação da equipe, embora quem tenha o contato com o usuário é quem produz a qualidade do atendimento; para atender ou não as expectativas. Assim sendo, várias dimensões gerencias devem estar envolvidas para a prestação de um serviço de qualidade.

As pessoas precisam entender e querer assumir novos papeis para provocar a melhoria da qualidade, 
“... o caminho da Qualidade, mais do que um controle de processos, depende fundamentalmente das pessoas, os trabalhadores, envolvidos; depende sobretudo, da educação que promova um clima de comprometimento e de motivação entre os funcionários, em todos os níveis da organização." (PAULINO, 2000, p. 208)

VANTI (1999, p. 338) relata a utilização da ferramenta denominada 5 S, na gestão de biblioteca, que tem por finalidade aprimorar o ambiente de trabalho, gerar estímulos para relacionamentos mais humanos e melhorar a qualidade de vida dos funcionários. Aponta como vantagem o baixo custo para sua utilização, frente às vantagens obtidas, “... substancial melhoria na prestação dos serviços e criar um clima de confiança, autodisciplina e responsabilidade que resultaram em um ambiente de qualidade no local de trabalho." 


\section{Gestão de pessoas e comprometimento}


O comportamento humano tem grande importância na vida e no desempenho das organizações, que dependem em diferentes graus, do desempenho humano para a consecução dos seus objetivos. Para alcançar isso, desenvolvem e organizam as relações organizacionais, e é nesse contexto que surge o conceito de modelo de gestão de seus recursos humanos, as pessoas.

"Quando esse conceito é estrategicamente orientado, sua missão prioritária consiste em identificar padrões de comportamento coerentes com o negócio da organização; a partir de então, obtê-los, mantê-los, modificá-los e associá-los com os demais fatores organizacionais será o objetivo principal"(FISCHER, 2002, p. 13)

O modelo de gestão de pessoas é portanto, a maneira pela qual uma empresa se organiza para orientar e gerenciar o comportamento humano no trabalho, definida e estruturada por alguns princípios, estratégias, políticas, práticas e mecanismos, através dos quais implementa as diretrizes e orienta a atuação dos gestores e suas equipes.

Algumas organizações produzem mais com mais qualidade do que outras, e isto não se deve apenas a aspectos de tecnologia, mas sobretudo à cultura inerente ou subjacente ao modelo administrativo adotado, que se reflete no envolvimento dos recursos humanos, bem como sua participação no processo produtivo, e na conseqüente garantia ou não da satisfação do cliente. 
O envolvimento das pessoas com a organização, está portanto, integralmente aliado ao comprometimento esperado, desses indivíduos com os objetivos e metas dessa organização.

ALBUQUERQUE (1999, p. 218) refere-se às organizações de concepção tradicional onde "... a participação do trabalhador individual deve estar limitada aos objetivos organizacionais ou à resolução de problemas relacionados à tarefa..." e àquelas com visão transformada, para as quais os objetivos passam a ser aqueles que atendem aos variados interesses e necessidades dos múltiplos envolvidos, e cuja função crítica passa a ser “... coordenar a lealdade e o comprometimento dos participantes com relação à sobrevivência dela a longo prazo e à rede social em que está inserida."

O autor recorre a Pfeffer (1995) para explicitar essa tendência,

"... atingir o sucesso competitivo através de pessoas, envolve fundamentalmente alterar como nós pensamos sobre a força de trabalho e as relações de emprego. Isso significa alcançar o escopo de suas atividades. E implica em visualizar a força de trabalho como uma fonte de vantagens estratégicas, e não como um custo a ser minimizado ou evitado."

\subsection{A IMPORTÂNCIA DAS PESSOAS NAS ORGANIZAÇÕES}

As organizações necessitam de um corpo gerencial e de colaboradores com nível de educação, formação e qualificação profissional cada vez mais maior, e nessa concepção, tecnologia e $\mathrm{RH}$ qualificados 
caminham juntos, na busca de inovação, qualidade dos serviços e produtividade (BONATO, 2003).

Desde o lançamento do "Princípios de Administração Científica" de Taylor, em 1911, e as recomendações de Fayol (1916) que preconizava a gerência composta por cinco partes: planejamento, organização, comando, coordenação e controle, muitos foram os caminhos trilhados pela administração nas organizações, até meados de 1927 e 1932, quando Elton Mayo aponta em seus estudos, que o que fazia a produção aumentar e melhorar era a possibilidade que o ser humano tem de satisfazer sua escala de necessidades no ambiente de trabalho, principalmente as de relacionamento humano, tratamento adequado, reconhecimento e recompensa; assim, cria a Escola de Relações Humanas, com subsídios para o atendimento, só então, das necessidades do ser humano, tendo como pontos principais, de acordo com MAXIMIANO (1990, p.77):

"1. O sistema social, formado pelos grupos, determina o resultado do trabalhador individual, que quase nunca coincide com os padrões impostos pela administração;

2. A administração não deve estabelecer relações com o indivíduo, mas com o grupo;

3. O supervisor de primeira linha deixa de ser um controlador para assumir o papel de intermediário entre a administração superior e os grupos de trabalho." 
É nessa década, de acordo com VIVAN, FRIES e ZANOTELLI (1998, p. 47),

“... que os operários iniciaram sua caminhada, no que se refere à participação conjunta aos objetivos próprios da empresa, estabelecendo-se um maior poder de comunicação entre empregado/empregador, que buscava a necessidade de ambos."

Os trabalhadores não fazem as mesmas coisas pelas mesmas razões e os motivos humanos variam de pessoa para pessoa, o que resulta em diferenças de comportamento; essa motivação portanto, pode ser caracterizada como um processo intrínseco ao indivíduo e que o impulsiona, o leva a atuar e a comportar-se de determinada maneira com relação ao mundo exterior.

"A motivação tem sido vista como uma saída para melhorar o desempenho profissional no que diz respeito tanto à produtividade quanto à saúde organizacional e satisfação dos trabalhadores. O papel do gestor deverá ser sempre o de identificar os norteadores de comportamento de seus subordinados, assumindo a natureza intrínseca e individual da motivação de modo a gerir a direção da energia que naturalmente se encontra dentro de cada um num sentido compatível com os objetivos da organização e com o crescimento de cada integrante de seu grupo de trabalho."(CASADO, 2000, p. 257)

BERGAMINI e BERALDO (1992, p. 29) valem-se de O'Shaughnessy 
para explicar o conceito:

“... quando estimulados dão origem a um comportamento que é dirigido para objetivos considerados como possíveis de serem satisfeitos. Se as necessidades e desejos das pessoas, isto é, seus motivos, fossem limitados em número e pudessem se identificados e medidos segundo a importância relativa, seria possível estruturar uma organização na qual o empregado melhor satisfizesse suas necessidades e desejos, contribuindo dessa forma, para os objetivos gerais da organização."

Ao se voltar para a importância capital das pessoas, no que tange ao desenvolvimento e capacitação, e a adoção do termo "pessoas", no lugar de "recursos humanos", cabe destacar o que considera Fischer (2002, p. 32), "Hoje, quando o papel do homem no trabalho vem-se transformando e suas características mais especificamente humanas, como o saber, a intuição e a criatividade, vem sendo valorizadas, talvez se caminhe para uma transição na qual a empresa finalmente reconheça que se relaciona com pessoas, e não com recursos."

\subsection{A gestão estratégica de PESSOAS}

Além da evolução dos modelos administrativos convergindo para a administração estratégica de pessoas, segundo ALBUQUERQUE (1999, p. 232), há também uma evolução do conceito de administração de Recursos Humanos como resultado da necessidade de planejamento e intervenções 
com orientação estratégica, visando à mudança do antigo modelo de controle para o modelo de comprometimento, que se contrapõem.

Ao discorrer sobre a gestão de Recursos Humanos, que anteriormente tinha seu foco maior na orientação para resultados, o autor aponta tendências que possibilitariam às organizações, 0 alcance de vantagens competitivas sustentáveis, pela força de trabalho:

“... deverão assumir como premissas as necessidades de:

a) valorização dos talentos humanos na empresa - trata-se de gerir o trabalho e as pessoas e não simplesmente recursos ou números; b) atração e manutenção de pessoas de alto potencial e qualificação para o trabalho; c) criação de condições favoráveis à motivação individual e à mobilização dos grupos em torno das metas organizacionais; d) possibilidades de crescimento funcional e desenvolvimento profissional na própria empresa; e) oferecimentos de incentivos vinculados a resultados da atividade empresarial, de preferência com base grupal e coletiva; f) adaptação de políticas integradas de recursos humanos à realidade da empresa e ao contexto externo econômico-social e político no qual atua."

A Administração Participativa dos anos 50, com base na ampliação de tarefas, no trabalho em equipe, na rotação de cargos, na delegação de poder, na autogestão e auto-liderança, juntamente com os novos instrumentos da Administração Estratégica dos anos 60, são vistas como as antecessoras da preocupação que as organizações têm demonstrado em 
buscar formas de gestão mais participativas, através da negociação para o envolvimento de seus funcionários, ao invés da imposição e do condicionamento financeiro.

Para SÁ e LEMOINE (1998), que investigaram a influência das condições de trabalho e as relações pessoais no comprometimento das pessoas, o estilo de liderança também influencia no comprometimento, que verifica-se ser maior nas gestões do tipo mais participativa.

DRUCKER (1990, p. 1) refere-se ao papel do líder, “... o líder tem que gerenciar a si próprio; conhecer as suas forças e coloca-las em benefício dos bons propósitos. A liderança começa, não quando você estabelece regras para os outros, mas quando você traça regras muito exigentes para si próprio.

Já Burns, citado por LAPIERRE (1995, p. 71) aborda liderança como, “... um processo recíproco de mobilização de recursos econômicos, políticos e outros, vivido num contexto de cooperação e conflito, por pessoas que possuem certas motivações e valores, para atingir objetivos perseguidos individual ou conjuntamente pelos líderes e seus seguidores."

Isso transposto para as bibliotecas, continua sendo verdadeira a afirmativa de que liderança é caracterizada pela atitude integrada e dirigida para um objetivo comum ao líder e ao grupo; depende da aceitação do líder pelo grupo de modo a conseguir uma integração também dos esforços; acontece num ambiente condicionado por forças sociais, formais e informais. 
Nas décadas de 70 e 80 foi introduzido o caráter estratégico, pela necessidade de vincular a gestão de pessoas às estratégias da organização, que de acordo com FISCHER (2002), ao citar Staehle (1990) e na perspectiva da Harvard Bussiness School, para a gestão estratégica de pessoas deverá ser buscado o melhor encaixe possível com as políticas empresariais e os fatores ambientais, considerando a influência sobre os funcionários, os processos de recursos humanos, o sistema de recompensas e os sistemas de trabalho.

Ainda nos anos 80 o autor Michael Porter edita as obras "Estratégia competitiva" e "Vantagem Competitiva das nações", com novos conceitos de estratégia e competitividade no âmbito empresarial, e em 1995, Prahalad e Hamel - "Competindo pelo futuro" - trazem, entre outros, o conceito de competências essenciais, para a busca de sobrevivência competitiva das empresas.

Por competências entendem FLEURY e FLEURY (2004, p. 27), baseados em Parry (1996) é,

o “...conjunto de conhecimentos, habilidades, atitudes que afetam a maior parte do trabalho de uma pessoa, e que se relacionam com o desempenho no trabalho; a competência pode ser mensurada, quando comparada com padrões estabelecidos e desenvolvida por meio do treinamento."

Um quadro sinótico das escolas/teorias de administração estratégica, é apresentado por MINTZBERG, AHLSTRAND e LAMPEL (2000), que 
apontam para as perspectivas de cada uma delas, como: design, planejamento, posicionamento, empreendedora, cognitiva, aprendizado, poder, cultural, ambiental e configuração. Cada uma delas complementa o quadro administrativo que trata da estratégia como um processo de mudança.

Numa definição mais ampla, ALBUQUERQUE (1999) cita Hyden (1986) e afirma que administração estratégica é o processo de administrar uma entidade de forma a atingir seu propósito. A administração da vantagem competitiva inclui identificar objetivos analisando o ambiente, reconhecer as ameaças e oportunidades formulando estratégias, implementado e monitorando-as de forma a sustentar as vantagens competitivas no mercado; é um enfoque que permeia a administração de todos os aspectos da companhia.

Ao abordar a administração estratégica dirigida aos recursos humanos, ALBUQUERQUE (2002, p. 38) relaciona as características relatadas por Anthony (1996):

- reconhece os impactos do ambiente organizacional externo,

- reconhece o impacto da competição e da dinâmica do mercado de trabalho,

- apresenta foco no longo prazo'

- enfatiza a escolha e a tomada de decisão

- considera todas as pessoas da empresa

- está integrada com a estratégia corporativa e com as demais estratégias funcionais. 
JUNQUEIRA e BARRETO (www.instotutomvc.com.br/insight72.htm) referem-se a estudos e pesquisas realizadas na Europa e EUA, que apontam que os colaboradores tornam-se

“... engajados/comprometidos quando: compreendem a organização; são envolvidos nas decisões; podem falar francamente de suas percepções/sentimentos; encontram espaço para crescerem e se desenvolverem profissionalmente; percebem que a empresa tem foco na orientação para resultados; sentem-se reconhecidos e recompensados por suas contribuições; sentemse competentes em sua capacidade de fazer diferença; sentem-se satisfeitos em relação aos diversos aspectos da organização; participam das decisões com a liderança; se identificam com os valores da organização; se identificam com as metas e objetivos da empresa."

Portanto, conhecer o engajamento e comprometimento dos funcionários pode representar um diferencial de competitividade e a obtenção de benefícios tangíveis em relação aos resultados finais.

\subsection{A BUSCA DO COMPROMETIMENTO ORgANIZACIONAL}

Nascida na Alemanha, após a $2^{a}$ Guerra Mundial, pode ser sintetizada, de acordo com CHANG JUNIOR (2001, p. 21) como,

“... a procura pela dinamização das relações internas, incentivando e utilizando as potencialidades dos empregados, 
para alcançar os objetivos: responsabilidades sociais da empresa, equilíbrio dos interesses dos vários envolvidos, cultura democrática, redução da alienação, utilização do potencial das pessoas, diminuição dos conflitos mediante a cooperação, satisfação das pessoas e maior competitividade."

ALBUQUERQUE, em 2002, realiza estudo retrospectivo da literatura a respeito do tema Comprometimento, e vale-se para isso da definição anteriormente dada por MOWDAY, STEERS e PORTER (1996, p. 226),

"Comprometimento é uma relação forte entre um indivíduo identificado com e envolvido numa organização em particular, e pode ser caracterizado por pelo menos três fatores: 1 - estar disposto em exercer um esforço considerável em benefício da organização, 2 - uma forte crença e a aceitação dos objetivos e valores da organização, e 3 - um forte desejo de se manter membro da organização."

A partir dessa definição esses autores propuseram e validaram um instrumento para medir o comprometimento, o Organizational Commitment Quiestionnaire - OCQ, e no Brasil, utilizando o mesmo instrumento, BORGES-ANDRADE, AFANASIEFF e SILVA (1989), construíram modelos que explicam o comprometimento para amostras de trabalhadores brasileiros e os resultados ressaltam a importância da oportunidade oferecida ao trabalhador (servidores públicos) para o seu crescimento e realização profissional. 
MEYER e ALLEN (1997), ao estudar o comprometimento organizacional, identificam três enfoques como principais:

1 - O comprometimento afetivo com a organização;

2 - O comprometimento instrumental, em que os empregados são movidos mais pela necessidade do emprego do que por estarem dispostos a fazer esforços em prol da organização;

3 - O comprometimento normativo, obtido por um conjunto de pressões normativas exercendo influência sobre 0 comportamento no trabalho.

O enfoque instrumental, que deriva dos estudos realizados por BECKER (1960) indica uma tendência do indivíduo permanecer na empresa devido aos custos e benefícios decorrentes de sua saída, chamadas pelo autor, de side bet, ou trocas laterais, como denominou BASTOS (1994) e assim esse indivíduo se engaja em linhas consistentes de atividades, para se manter no emprego; essa noção de linhas consistentes de atividades significa a escolha feita pelo indivíduo, entre diversas alternativas, daquela que atende melhor os seus propósitos.

No enfoque normativo, o elemento central da definição é a aceitação, por parte do indivíduo, dos valores e objetivos organizacionais, representando uma forma de controle sobre as ações das pessoas. WIENER (1982, p. 421) o denomina de normativo-instrumental, e alega que os indivíduos comprometidos adotam determinados comportamentos, porque consideram que é "certo" fazê-lo, e o autor assim explica o conceito: “... a 
totalidade das pressões normativas internalizadas para agir num caminho que encontra os objetivos e interesses organizacionais."

MEDEIROS, ALBUQUERQUE, SIQUEIRA e MARQUES (2005), compilaram, o que chamaram de componentes do comprometimento e descreveram suas dimensões de acordo com os principais autores:

\begin{tabular}{|c|c|}
\hline Kelman (1958) & $\begin{array}{l}\text { a) Submissão ou envolvimento instrumental, motivado por } \\
\text { recompensas extrínsecas; } \\
\text { b) Identificação ou envolvimento baseado num desejo de } \\
\text { afiliação } \\
\text { c) Internalização ou envolvimento causado pela congruência } \\
\text { entre os valores individuais e organizacionais }\end{array}$ \\
\hline Gouldner(1960) & $\begin{array}{l}\text { a) Integração - o grau em que o indivíduo é ativo e se sente } \\
\text { parte } \\
\text { b) Introjeção - o grau em que a própria imagem de um } \\
\text { indivíduo inclui uma variedade de características e valores } \\
\text { organizacionais. }\end{array}$ \\
\hline Etzioni (1961) & $\begin{array}{l}\text { a) Envolvimento oral, baseado na internalização dos } \\
\text { objetivos, valores e normas da organização, sendo positivo e } \\
\text { intenso na direção dos objetivos organizacionais; } \\
\text { b) Envolvimento calculativo, baseado nas relações de troca } \\
\text { que se desenvolvem entre o membro e sua organização. É } \\
\text { uma relação de menor intensidade e ocorre quando o membro } \\
\text { percebe equidade entre recompensas e contribuições. } \\
\text { c) Envolvimento alienativo, baseado na repressão e na } \\
\text { coerção. Tem orientação negativa e é encontrado em } \\
\text { ambientes como prisões. }\end{array}$ \\
\hline Kanter (1968) & $\begin{array}{l}\text { a) Coesão - vínculo às relações sociais da organização, } \\
\text { realizadas em técnicas e cerimônias que tornam público o } \\
\text { estado de ser de um membro da organização e que reforçam a } \\
\text { coesão do grupo; } \\
\text { b) Continuação - requer dos membros da organização a } \\
\text { realização de sacrifícios pessoais e de investimentos que } \\
\text { tornam difícil aos membros deixar a organização; } \\
\text { c) Controle - vínculo de um membro às normas de uma } \\
\text { organização que moldam seu comportamento numa direção } \\
\text { desejada. }\end{array}$ \\
\hline $\begin{array}{l}\text { Meyer e Allen (1990, } \\
\text { 1991, 1993) }\end{array}$ & $\begin{array}{l}\text { a) Afetivo - como um apego, um envolvimento, onde ocorre } \\
\text { identificação coma a organização } \\
\text { b) Tratado na literatura como instrumental - percebido como } \\
\text { custos associados a deixar a organização (..." os empregados } \\
\text { permanecem porque precisam...") } \\
\text { c) Obrigação de permanecer na organização. Os autores } \\
\text { reconceitualizaram (1993) como normativo }\end{array}$ \\
\hline
\end{tabular}


Popper e Lipshitz (1992), citados por BASTOS (1994, p. 41) em estudo quantitativo, apontam a inexistência de consenso sobre comprometimento organizacional, na literatura mundial:

"À diversidade de definições, com raízes em distintas disciplinas científicas que contribuem para a compreensão do comprometimento organizacional, associam-se operacionalizações diversas do constructo, o que constitui uma fonte adicional e importante de fragmentação da área."

Outros estudos brasileiros ressaltam que os principais antecedentes do comprometimento têm ênfase na troca indivíduo-organização na medida em que estas oferecem suporte para a realização dos objetivos de crescimento, desenvolvimento pessoal e profissional, distribuídos eqüitativamente entre seus recursos humanos.

DESSLER (1996, p. 11) a partir de estudo com duração de trinta anos, depõe,

"Uma coisa que tornou-se cada vez mais óbvia, à medida que meu estudo prosseguia foi a criação do comprometimento que requeria um programa administrativo abrangente, composto de um pacote de práticas administrativas concretas e políticas de pessoal. $\mathrm{Na}$ falta de tal programa, os resultados dos esforços relativamente unidimensionais, como programas de aumento de qualidade ou planos de incentivo estão fadados ao fracasso." 
DINIZ DE SÁ (1998), constata que o comprometimento é função da coerência entre a cultura da empresa, pelo estilo de liderança e da cultura dos empregados.

Uma importante variável que precede o comprometimento é a comunicação; representando um importante processo administrativo; é pela comunicação que a empresa se relaciona com os ambientes internos e externos, principalmente se considerado que o resultado final é alcançado por um conjunto de pessoas ou equipes, que devem estar dispostas a receber informações passadas por outras pessoas.

Representam, em alguns casos, pré-condição para o sucesso do trabalho em equipes, pela importância fundamental da comunicação que deve ocorrer entre os grupos e suas chefias, além de manter claro para os membros dessas equipes, o desafio que juntos devem enfrentar. A discussão das metas tem papel crucial, no sentido do conhecimento e do comprometimentos de todos os membros, e a divulgação final do desafio superado e de seus resultados significa a coroação da satisfação alcançada pelo grupo. (ALBUQUERQUE, 1999)

Na visão de LIKERT (1971) as teorias clássicas da administração não dão à comunicação a mesma importância que dão ao controle e às cadeias de comando, o que faz com que fatores humanos como, relacionamentos interpessoais e percepções sobre o trabalho, fiquem em segundo plano, e isso não promove o comprometimento das equipes. 
Também a criatividade, definida como “... 1.qualidade de criativo; 2. Capacidade criadora; engenho, inventividade." no Novo Dicionário Aurélio da Língua Portuguesa de 1986, é incluída no estudo de CHANG JUNIOR (2001, p. 40), ao propor um modelo teórico para a explicação do comprometimento organizacional, como uma variável quantitativa, “... o fator criatividade é confiável e único como uma medida de característica da organização ou do trabalho."

Esse autor ainda considera que o comprometimento parece ser uma resposta do indivíduo às organizações que oferecem suporte para a consecução de seus objetivos de crescimento, desenvolvimento pessoal e profissional, em um contexto de equidade no tratamento dos seus recursos humanos.

DERTOUZOS e LESTER (1990), reconhecendo a relevância do comprometimento da força de trabalho, incorporada com os contornos da humanização, afirmam que empresas bem sucedidas reconhecem que incrementos na qualidade requerem níveis de comprometimento, responsabilidade e conhecimento por parte das equipes e que estes incrementos não podem ser obtidos por coerção ou melhorias cosméticas nas políticas de recursos humanos.

Embora só o comprometimento não garanta a qualidade e o sucesso de produtos ou serviços, a ausência dele, ou em nível muito aquém do desejado, podem inviabilizar um processo ainda que bem definido e estruturado, bem como levar à desagregação do grupo de pessoas que se pretende envolver. 
Fundamentalmente, o comprometimento das pessoas depende da junção dos objetivos da empresa e de seus colaboradores, tal como na abordagem de DESSLER (1996, p. 16):

“... a forma mais poderosa de garantir a execução correta do trabalho da organização é sincronizar as suas metas com as de seus funcionários - garantir, em outras palavras, que os dois conjuntos de metas sejam essencialmente os mesmos, de modo que, ao procurar realizar suas próprias metas, o funcionário procure realizar também as metas da organização; criar comprometimento significa realizar essa síntese".

Reintera que a criação do comprometimento pressupõe um programa administrativo abrangente, com práticas administrativas concretas e políticas de recursos humanos.

Com vistas ao comprometimento das equipes de funcionários, a cultura organizacional precisa ser conhecida pelos administradores, inclusive como requisito para eventuais necessidades de mudança, da cultura das organizações com as quais estão envolvidos, e é geralmente explicada como o conjunto dos pressupostos básicos que um grupo define, ao lidar com problemas de adaptação externa ou integração interna e que são considerados válidos e são ensinados a novos membros, como a forma correta de perceber, pensar e sentir, com relação a estes mesmos problemas.

Planos e estratégias tem sido utilizados, na busca do comprometimento da força de trabalho para alcançar resultados e o 
envolvimento dos colaboradores com os objetivos da organização, favorece a consecução desses resultados, portanto é importante identificar fatores, acontecimentos ou ações que influenciam o ambiente e o comportamento das equipes. Promover a capacitação das pessoas leva ao aperfeiçoamento e alinhamento das equipes na consecução dos objetivos pretendidos pela organização.

KOTLER e FOX (1994, p. 148), ao tratar especificamente das instituições educacionais, no que se refere à composição da missão da instituição, afirmam “... que as mesmas precisam prestar atenção às suas competências exclusivas que são aqueles recursos e habilidades em que a instituição é especialmente forte."

O trabalho em equipes tem sido uma das alternativas viáveis de gestão de recursos humanos e tem como objetivo aumentar a produtividade, a competitividade e a eficiência, tornando o trabalho mais ágil, integrado e entrosado, em que a multifuncionalidade e as habilidades contribuem para o crescimento global do trabalhador. (CASADO e MATOSO, 1996) 


\subsubsection{A PESQUISA SOBRE COMPROMETIMENTO}

BASTOS (1993) examinando a literatura sobre o tema, reconstituiu a investigação sobre o tema comprometimento organizacional, discutindo as vertentes de conceituação da sociologia, das teorias organizacionais e da psicologia social, apresentadas a seguir:

\begin{tabular}{|c|c|c|c|c|c|}
\hline Enfoque & $\begin{array}{l}\text { Autoridade no } \\
\text { contexto de trabalho }\end{array}$ & Instrumental & Afetivo & Normativo & Comportamental \\
\hline $\begin{array}{l}\text { Conceitos de } \\
\text { comprometi- } \\
\text { mento }\end{array}$ & $\begin{array}{l}\text { - Interesse em } \\
\text { continuar no emprego } \\
\text { atual por perceber a } \\
\text { legitimidade da } \\
\text { relação de } \\
\text { autoridade- } \\
\text { subordinação; } \\
\text { - O papel da } \\
\text { subordinação envolve } \\
\text { códigos normativos } \\
\text { sobre modos corretos } \\
\text { de dominação. }\end{array}$ & $\begin{array}{l}\text { - Tendência de se } \\
\text { engajar em linhas } \\
\text { consistentes de } \\
\text { atividades; } \\
\text { - Mecanismo } \\
\text { psicossocial que } \\
\text { envolve trocas e } \\
\text { investimentos } \\
\text { limitantes. }\end{array}$ & $\begin{array}{l}\text { - A força relativa } \\
\text { da identificação e } \\
\text { envolvimento com } \\
\text { uma organização } \\
\text { particular; } \\
\text { - Forte crença e } \\
\text { aceitação dos } \\
\text { objetivos e valores; } \\
\text { - Desejo de } \\
\text { esforçar-se pela } \\
\text { organização; } \\
\text { - Forte desejo de } \\
\text { permanecer como } \\
\text { membro. }\end{array}$ & $\begin{array}{l}\text { - Totalidade de } \\
\text { pressões } \\
\text { normativas } \\
\text { internalizadas } \\
\text { pelo indivíduo } \\
\text { para que se } \\
\text { comporte de } \\
\text { acordo com os } \\
\text { objetivos e } \\
\text { interesses da } \\
\text { organização. }\end{array}$ & $\begin{array}{l}\text { - Um estado de } \\
\text { ser em que as } \\
\text { ações determinam } \\
\text { crenças que } \\
\text { sustentam a } \\
\text { atividade e seu } \\
\text { próprio } \\
\text { envolvimento. }\end{array}$ \\
\hline
\end{tabular}

Adaptado de Bastos, AVB. Comprometimento organizacional: um balanço dos resultados e desafios que cercam essa tradição de pesquisa. RAE (São Paulo) 33 (3): 52-64, 1993.

\section{MEDEIROS, ALBUQUERQUE, SIQUEIRA e MARQUES (2005)}

realizaram estudo retrospectivo das vertentes conceituais do comprometimento e da literatura e pesquisas internacionais e nacionais do tema, nas suas diversas abordagens e focos, na década de 90 . Das agendas internacionais de pesquisa, são citadas:

- Organizational Commitment Questionaire (Mowday, Steers e Porter, 1979);

- Employee-Organization Linkage: The psychology of commitment, absenteism and turnover (Mowday, Porter e Steers, 1982); 
- Mathieu e Zajac (1990); Meyer e Allen (1997) e Mowday (1998);

- além das pesquisas e ensaios apresentados nos Encontros da Associação Nacional dos Programas de Pós-Graduação em Administração.

Concluem que o conceito do comprometimento ainda está em construção e que futuras pesquisas deverão ampliar a dimensionalidade do conceito, com novos componentes e novas mensurações e buscar provar a relação do elevado nível de comprometimento dos empregados com o desempenho superior da organização, uma vez que as pesquisas o indicam como variável determinante nos resultados organizacionais. Recomendam ainda a avaliação de sistemas de recursos humanos para a promoção do comprometimento organizacional e afirmam a importância crescente do tema no campo da ciência administrativa, bem como dos progressos em termos de quantidade e qualidade das pesquisas brasileiras do comprometimento.

BASTOS (1994, p. 58) considerando as mudanças ocorridas nas arquiteturas organizacionais e nas hierarquias das carreiras profissionais e as implicações dessas mudanças, acrescidas do impacto das novas tecnologias sobre o comprometimento organizacional, aponta esse contexto como especial para a investigação sobre como os trabalhadores articulam seus vínculos afetivos, cognitivos e comportamentais com as organizações e as suas profissões/carreiras. À luz de descrições e achados internacionais sobre o tema comprometimento, propõe quatro padrões de comprometimento tomando como focos a organização e a carreira/ profissão. 
1 - Duplo compromisso (mesmo nível de comprometimento com a organização e com a profissão),

2 - Duplo descompromisso (o nível do comprometimento organizacional é maior do que o do comprometimento profissional),

3 - Unilateral com a organização (elevado nível de comprometimento com a organização),

4 - Unilateral com a profissão (elevado comprometimento com a profissão).

De acordo com o autor,

“... percebe-se que o comprometimento ante os dois focos é mediado pelo nível em que a profissão exercida é compatível com os interesses e a vocação individual e pelo nível em que o indivíduo encontra, na organização e no trabalho que aí realiza, condições propícias à realização profissional." 
5 O Sistema Integrado de Bibliotecas da Universidade de São Paulo - SIBi/USP 
A partir do Diagnóstico das bibliotecas da Universidade de São Paulo, elaborado por um grupo de trabalho designado pelo Magnífico Reitor, em 1980, com uma análise das bibliotecas universitárias, foi estabelecido em 1981, e aprovado em 1985, o denominado Sistema Integrado de Bibliotecas da Universidade de São Paulo - SIBi/USP, integrando tanto as bibliotecas dos campi da cidade de São Paulo como do interior, tendo como finalidade “...criar condições para as atividades sistêmicas das bibliotecas da USP, para oferecer suporte ao desenvolvimento da pesquisa e do ensino" (PASQUARELLI e KRZYZANOWSKI, 1988, p. 60).

Integra portanto, bibliotecas universitárias que tiveram sua origem, de acordo com McGARRY (1999, p. 76), “...em instituições chamadas studia generalia universitatis, reconhecida pela última palavra como uma universidade...". Nestes locais, intelectualmente mais autônomos do que os estabelecimentos monásticos estritamente regulados, clérigos e leigos eram educados e freqüentemente voltavam às instituições e doavam suas anotações de aulas e textos, frutos de seus aprendizados às respectivas bibliotecas universitárias que se então se iniciavam.

De acordo com seu Regimento Interno, consolidado pela Resolução da Reitoria, nº 3571 de 29/08/1989, o SIBi/USP é composto de um Conselho Supervisor - CS/SIBi, um Departamento Técnico - DT/SIBi e de um conjunto de 41 bibliotecas, instaladas junto às Unidades dos diversos campi.

O SIBi/USP tem como visão: Estabelecer modelo de sistema de bibliotecas a partir da definição de políticas, desenvolvimento de programas 
cooperativos intra e interinstitucionais para geração de produtos e serviços, centrados no interesse do usuário, e em consonância com normas e padrões internacionais de transcrição e de intercâmbio de informação a seguinte estrutura:

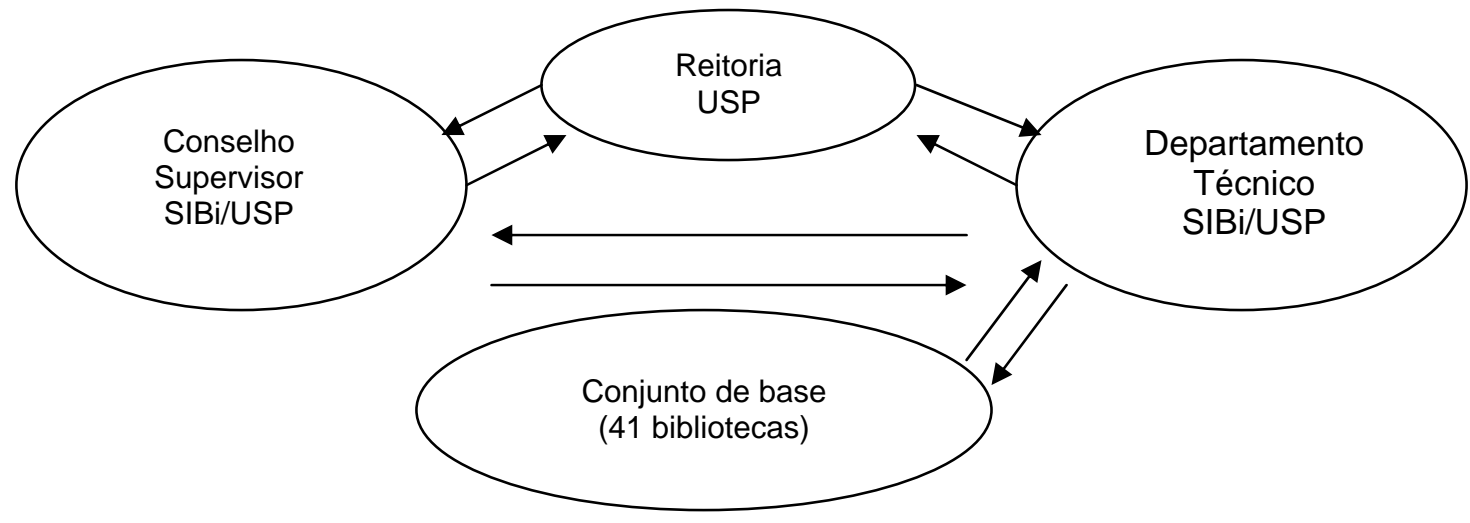

O SIBi/USP tem como missão: Promover o acesso à informação, por meio de programas cooperativos e de racionalização, com o estabelecimento de políticas, compartilhamento de recursos e normalização de procedimentos, no âmbito das bibliotecas da USP.

\subsection{As AÇÕES DE CAPACITAÇÃO PARA O COMPROMETIMENTO}

No cumprimento dos papéis que cabem às bibliotecas do Sistema, o DT-SIBi, recebe de cada uma delas, sugestões de estratégias e ações a serem incorporadas ao seu Planejamento Estratégico - PE; e essas sugestões podem ser somadas, integradas ou adotadas separadamente e representam tanto a especificidade e as necessidades cada uma das 
Bibliotecas como o caminho para a consolidação da estratégia maior e geral do DT/SIBi.

Com base nessa prática e do uso dessa ferramenta que é o planejamento estratégico, são delineadas e depois estabelecidas diretrizes administrativas e de condução das atividades a serem desenvolvidas no âmbito sistêmico.

Ao abordar o planejamento estratégico em Unidades de Informação, que neste caso, cabe perfeitamente às bibliotecas e ao Departamento Técnico do SIBi/USP, BARBALHO e BERAQUET (1995, p. 45), consideram dois aspectos importantes:

“...a - Unidade de Informação não existe como um órgão isolado, está sempre subordinada a uma instituição maior, necessitando conhecer as estratégias institucionais adotadas e sob elas elaborar o planejamento estratégico para si; b - o planejamento estratégico deve ser integrado em todos os setores da Unidade de Informação, sendo portanto necessário que todos os funcionários conheçam e participem das estratégias estabelecidas".

Identificadas no PE, além de estarem previstas nas políticas estabelecidas pelo DT, as questões que envolvem capacitação e qualificação de pessoas, tem recebido especial importância nas atividades e Projetos do DT-SIBI, uma vez que, os resultados de desempenho e os padrões de Qualidade, da prestação de serviços nas Bibliotecas do Sistema, dependem das competências de suas equipes. 
Diversas ações para o alcance da Qualidade foram implantadas e desenvolvidas no âmbito do Sistema, por iniciativa do DT-SIBi no bojo do Decreto nำ 40.536, assinado pelo então Governador Mario Covas, em 12 de dezembro de 1995, instituindo o Programa Permanente de qualidade e Produtividade no Serviço Público do Estado de São Paulo, incluindo as universidades, com o objetivo de ..."garantir ao cidadão o atendimento eficaz de suas necessidades, pela melhoria contínua e permanente dos serviços prestados, com redução de custos e ganjos de produtividade."

O Programa de Avaliação da Qualidade e o Sistema de Gestão para a Qualidade foram assim descritos em NOGUEIRA DA CRUZ e MIRANDA $(2005$,

p. 35) em relatório do Programa Permanente da Qualidade e Produtividade da Universidade de São Paulo: " O SIBi, a partir de 2002, instituiu o Programa de Avaliação de Qualidade (PAQ) das Bibliotecas, com o objetivo de avaliar continuamente a qualidade dos produtos e serviços oferecidos pelas 40 bibliotecas integrantes do SIBi/USP. A partir dessa avaliação foram implementadas ações que atendem às necessidades dos usuários. Ainda no $\mathrm{SIBi}$, e a partir da experi6encia de gestão de qualidade, na biblioteca da ESALQ, já referenciado e concluído com a conquista da medalha de bronze em 2003, foi iniciado em 2004, um processo semelhante em 15 bibliotecas e no Departamento Técnico do Sistema."

KOTLER e FOX (1994, p. 148), ao tratar especificamente das instituições educacionais, no que se refere à composição da missão da instituição, afirmam "... que as mesmas precisam prestar atenção às suas 
competências exclusivas que são aqueles recursos e habilidades em que a instituição é especialmente forte."

Dentre as sugestões que compõem o PE, estão presentes aquelas que tratam das necessidades de capacitação para as equipes das bibliotecas (bibliotecários, técnicos e funcionários básicos de biblioteca), o dimensionamento das equipes, competências e características individuais e das equipes para o bom desempenho de suas atividades, e outros quesitos, na busca do ideal da Qualidade na prestação dos serviços de informação.

Tem merecido destaque, como uma das metas do DT/SIBi, a promoção de capacitação das pessoas que trabalham no Sistema, para o aperfeiçoamento e alinhamento das equipes das bibliotecas na consecução dos objetivos pretendidos.

“Em 2005 o Programa de Capacitação foi desenvolvido de acordo com as Diretrizes para capacitação de equipes do SIBi/USP, documento norteador do processo, para atendimento à demanda de capacitação: necessidades individuais dos funcionários das bibliotecas e do DT/SIBi, remanescente de levantamento anterior, (2002); projetos em andamento, decorrentes do Planejamento Estratégico do SIBi/USP - 2005, e de projetos de contingência, identificados pelo DT/SIBi." (USP/SIBi/DT 2006 p. 15).

De acordo com o mesmo relatório foram capacitados 2.468 funcionários do Sistema, nos níveis superior, técnico e básico, nas áreas: 
gerencial, capacitação para serviços e tecnologia de informação e comunicação.

Através da análise de documentação do Departamento Técnico que culminou com o Programa de Capacitação de Recursos Humanos, no Curso: Comprometimento e Inovação - Revitalização do SIBi/USP, é possível conhecer a trajetória do DT na busca do crescimento profissional, pela capacitação, dos profissionais das três categorias de todas as Bibliotecas do Sistema.

Desde a capacitação dada às equipes das bibliotecas do Sistema para a automação do Banco Bibliográfico Institutucional Dédalus, em 1990, e do I Seminário de Preservação e Conservação de Bens Culturais: Papel, tem sido adotadas pelas diversas equipes gestoras que se seguiram, outras iniciativas para capacitar equipes dessas bibliotecas:

$\checkmark 1992$ - A partir de reuniões para avaliar produtividade e aperfeiçoamento do do Sistema, são montadas equipes de melhorias chamadas "Metas", em número de 9, cad uma delas trabalhando num tema específico, do rol de atividades das bibliotecas;

$\checkmark 1994$ - Projeto de Modernização do SIBi/USP. Projeto apresentado à FAPESP para capacitação de Equipes em Conservação e Restauro. Criação do espaço no DT/SIBi, do Centro de Capacitação SIBi/USP;

$\checkmark 1995$ - Início de treinamentos para o Sistema Aleph no DT/SIBi;

$\checkmark 1996$ - PROCAP SIBi/USP : Programa de Capacitação do SIBi/USP para o triênio 1996/1998; 
$\checkmark 1997$ - Treinamento do Aleph, extensivo a todas as Bibliotecas do Sistema. Catalogação cooperativa em linguagem MARC no Catalogo Coletivo Internacional da OCLC - Online Computer Library Center (Ohio, EUA);

$\checkmark 1998$ - Implantação da Comutação Bibliográfica Eletrônica com treinamento no uso do software Ariel;

$\checkmark 1999$ - Biblioteca Virtual na SIBiNet;

$\checkmark 2001$ - Vocabulário Controlado da USP: descritores para indexação e recuperação de informações na USP. Participação no Portal do Conhecimento SABER (Biblioteca Digital de Teses e Dissertações da USP). PROTAP I e II - Programa de Administração da Inovação Científica e Tecnológica nos Serviços de Informação. Novo Modelo de Gestão;

$\checkmark 2002$ - PAQ - Programa de Avaliação da Qualidade;

$\checkmark 2003$ - Programa de Capacitação "Comprometimento e inovação: revitalização do SIBi/USP - quando foram treinados 370 funcionário do Sistema.

$\checkmark 2004$ - SDG - Sistema de Gestão para a Qualidade, sob orientação da FEALQ- Fundação da Escola de Agronomia Luiz de Queiroz;

$\checkmark 2005$ - Continuidade do SDG, com a implantação de novas fases do Sistema de Gestão. 
6 Justificativa 
O Sistema Integrado de Bibliotecas da USP - SIBi/USP, composto de 41 bibliotecas, tem investido na capacitação e desenvolvimento profissional de suas equipes, com vistas à melhoria da qualidade na prestação de serviços. Tem adotado “... uma política de adequação dos recursos humanos às inovações e/ou modernizações de processos/atividades ocorridas em função da implementação de novas tecnologias e posturas gerenciais." (BELLUZZO, CARVALHO, FERRARI, SOUZA e FLEXA, 1996, 6.11)

A autora, ao pesquisar o que pensam os integrantes das equipes bibliotecárias, ou seja, os profissionais bibliotecários e funcionários dos níveis técnico e básico do SIBi/USP, pretende conhecer a representação social desses grupos profissionais em relação ao tema do Comprometimento Organizacional.

Estudos de natureza quantitativa têm sido publicados, abordando a validação e a utilização de instrumentos que avaliam o Comprometimento, assim como a evolução do conceito, contribuindo para a construção e o enriquecimento do tema, uma vez que não há consenso na literatura.

As abordagens acontecem, geralmente, na vertente que expressa o interesse dos gerentes em saber o quanto ou de que maneira as equipes estão comprometidas e nos instrumentos e metodologias utilizados para isso.

Mais do que entender, sob o ponto de vista da literatura existente, ou avaliar o Comprometimento desses profissionais sob a ótica dos gerentes ou 
dos gestores, este trabalho pretende dar voz aos sujeitos da pesquisa, considerando a possibilidade que os próprios sujeitos, como atores nas relações com a instituição, no caso das bibliotecas do SIBi/USP, possam explicitar suas opiniões sobre o tema.

O desenho da pesquisa, além de apreender as opiniões, as contextualiza no Sistema de Bibliotecas, de forma a oferecer, tanto quanto possível, um panorama do Comprometimento e suas relações com as atividades e com o ambiente de trabalho, sob a ótica e as particularidades de cada um desses atores: suas razões, suas escolhas e suas disposições para comprometer-se.

Como norteadoras de ações de sensibilização das pessoas do Sistema de Bibliotecas, as representações contidas nesse estudo poderão constituir-se em informação, tanto para as pessoas que compõem as equipes, como para aqueles que as gerenciam e estabelecem as diretrizes, para as ações ou para os programas de capacitação e desenvolvimento profissional no âmbito das bibliotecas, com vistas ao comprometimento das equipes. 


\section{Objetivos}


$\checkmark$ Identificar, através dos discursos dos profissionais de biblioteca (bibliotecários, técnicos e básicos) do Sistema Integrado de Bibliotecas da USP - SIBi/USP, que atuam na área da saúde suas opiniões sobre Comprometimento organizacional;

$\checkmark$ Apreender as opiniões desses profissionais do SIBi/USP a respeito do que, para eles significa, Comprometimento organizacional no contexto da missão do Sistema Integrado de Bibliotecas - SIBi/USP;

$\checkmark$ Analisar as respostas ao questionário, verificando quais são, para os sujeitos de pesquisa das bibliotecas do SIBi/USP na área da saúde, suas opiniões sobre os esforços empreendidos pelo Departamento Técnico - DT/SIBi/USP, na busca de equipes comprometidas. 
8 Método 


\subsection{O TIPO DA PESQUISA}

Para pesquisar o que pensam os indivíduos que fazem parte da coletividade denominada Equipes Bibliotecárias (bibliotecários e funcionários de nível técnico e básico) do Sistema Integrado de Bibliotecas da Universidade de São Paulo, foi utilizado estudo de natureza exploratória, de método qualitativo, ou de acordo com MINAYO (2000, p. 22), “...o caminho e o instrumental próprios de abordagem da realidade", qual seja, de acordo com a mesma autora - capaz de incorporar o significado e a intencionalidade inerentes aos atos, às relações e às estruturas sociais.

A mesma autora, pondera a respeito da representação social de indivíduos e grupos,

“... de um lado temos que o homem é o produto de seu produto: as estruturas da sociedade criam seu ponto de partida; de outro, temos que esse homem constrói a história dentro das condições recebidas ultrapassando-as, e inscreve sua significação por toda parte, em todo o tempo e na ordem das coisas."

Segundo JODELET (2001, p. 17),

“... há necessidade de estarmos informados sobre o mundo à nossa volta. Além de nos ajustarmos a ele, precisamos saber como nos comportar, domina-lo física ou intelectualmente, identificar e resolver os problemas que se apresentam: é por isso que criamos representações ... elas circulam nos discursos, são 
trazidas pelas palavras e veiculadas em mensagens e imagens midiáticas, cristalizadas em condutas e em organizações ..."

A autora, reconhece as representações sociais, “... enquanto sistemas de interpretação que regem nossa relação com o mundo e com os outros - orientam e organizam as condutas e as comunicações sociais Da mesma forma, elas intervêm em processos variados, tais como a difusão e a assimilação dos conhecimentos, o desenvolvimento individual e o coletivo, a definição das identidades pessoais e sociais, a expressão dos grupos e as transformações sociais."( $p$ 22)

LEFÈVRE, LEFÈVRE e TEIXEIRA (2000, p. 13) referem-se a um modo de conceber as representações sociais,

“... consiste em entendê-las como a expressão do que pensa ou acha determinada população sobre determinado tema. Este pensar, por sua vez, pode se manifestar ,dentre outros modos, através do conjunto de discursos verbais emitidos por pessoas dessa população."

\subsection{A METODOLOGIA}

Foi utilizado o proposto no livro 0 Discurso do Sujeito Coletivo: um novo enfoque em pesquisa qualitativa (desdobramentos), dos autores Fernando Lefévre e Ana Maria Simioni Lefèvre, de 2003, como uma proposta desses autores para organizar e tabular dados qualitativos de 
natureza verbal e que “...consiste basicamente, em analisar o material verbal coletado extraindo-se de cada um dos depoimentos, artigos, cartas, papers as idéias-centrais e/ou ancoragens e suas correspondentes expressõeschave...", com as quais compõe-se um ou vários discursos-síntese (p.16).

$\checkmark$ Expressões-chave $(\mathrm{ECH})$ são trechos ou transcrições literais do discurso, sublinhadas pelo pesquisador e que revelam a essência do depoimento ou, mais precisamente, do conteúdo discursivo dos segmentos do depoimento. O que se busca é resgatar a literalidade do depoimento. É com a matéria-prima das expressões-chave que se constroem os Discursos do Sujeito Coletivo.

$\checkmark$ Idéias centrais (IC) é o nome ou expressão linguística que revela e descreve sinteticamente o sentido de cada um dos discursos analisados e de cada conjunto homogêneo de $\mathrm{ECH}$.

$\checkmark$ Ancoragem (AC) é considerada a “... manifestação lingüística explícita de uma dada teoria ou ideologia ou crença que o autor do discurso professa...", podendo aparecer ou não no depoimento colhido e correspondem a mais uma figura metodológica inspirada na teoria da representação social.

$\checkmark$ Discurso do Sujeito Coletivo (DSC) é um discurso-síntese, redigido na primeira pessoa do singular, composto pelas $\mathrm{ECH}$ que têm a mesma IC ou AC.

“... com o DSC os discursos dos depoimentos não se anulam ou se reduzem a uma categoria comum unificadora já que o que se 
busca fazer é reconstruir, com pedaços de discursos individuais, como em um quebra-cabeça, tantos discursos-síntese quantos se julgue necessários para expressar uma dada "figura", ou seja, um dado pensar ou representação social sobre um fenômeno" (p. 19).

Os mesmos autores (1998) recomendam a utilização de entrevista semi-estruturada, com os sujeitos de pesquisa, pois este tipo de entrevista nos permite, através de um discurso, que é o modo como naturalmente as pessoas pensam, o acesso a dados da realidade que são de caráter subjetivo, mas podem trazer à luz questões, que de outro modo permaneceriam obscuras.

MINAYO (2000, p. 110) considera a entrevista um instrumento privilegiado de coleta de informações pela,

“... possibilidade de a fala ser reveladora de condições estruturais, de sistemas de valores, normas e símbolos... e ao mesmo tempo ter a magia de transmitir, através de um porta-voz, as representações de grupos determinados, em condições históricas, sócio-economicas e culturais específicas."

\subsection{O UNIVERSO E A AMOSTRA DA PESQUISA}

Considerando o desenho geral da pesquisa, foram selecionadas para o estudo, as bibliotecas da área da saúde humana, que no Sistema Integrado de Bibliotecas da USP, estão no grupo de bibliotecas da área biológica nas seguintes Unidades de ensino: 
Prefeitura Campus Administrativo de Ribeirão Preto - Faculdade de Medicina de Ribeirão Preto / Faculdade de Odontologia de Ribeirão Preto / Faculdade de Enfermagem de Ribeirão Preto / Instituto de Psicologia de Ribeirão Preto

Faculdade de Medicina

Hospital Universitário

Instituto de Ciências Biomédicas

Faculdade de Saúde Pública

Instituto de Psicologia

Faculdade de Odontologia de Bauru

Faculdade de Odontologia de Bauru - Seção de referência especializada em malformações congênitas craniofaciais

Faculdade de Odontologia

Escola de Educação Física e Esporte

Escola de Enfermagem

\subsubsection{OS SUJEITOS DA PESQUISA}

A população alvo foi composta pelos funcionários bibliotecários, técnicos e básicos dessas bibliotecas, escolhidos aleatoriamente pelo menos três profissionais: 01 bibliotecário, 01 técnico de biblioteca e 01 profissional de nível básico, para cada uma das 14 bibliotecas da área da saúde, uma vez que, essas três categorias funcionais do SIBi/USP, têm sido alvo de incentivo à capacitação e têm participado dos programas institucionais de treinamento. As pessoas ouvidas foram abordadas nos seus locais de 
trabalho, para a aplicação das entrevistas ou ofereceram-se para a entrevista ou ainda foram sugeridas, no momento da aplicação do questionário, pela Diretora técnica das bibliotecas visitadas. No total são 44 os sujeitos de pesquisa, pois foram ouvidos também os sujeitos que se ofereceram à participação, quando da visita da pesquisadora às bibliotecas para o recolhimento dos depoimentos, alem daquelas cujos depoimentos já haviam sido colhidos.

A entrevista com cada um desses sujeitos de pesquisa, foi feita com base em um roteiro de pesquisa (Anexo II) constante de 06 perguntas, as mesmas, para as três categorias de profissionais (bibliotecários, técnicos e básicos).

Antecedendo as entrevistas, foi apresentado para cada um dos sujeitos de pesquisa o Termo de Consentimento Livre e Esclarecido, (Anexo I) elaborado pela pesquisadora, conforme recomendação do Comitê de Ética em Pesquisa da Faculdade de Saúde Pública da Universidade de São Paulo, atendendo à Resolução 196, de 10 de outubro de 1996, do Conselho Nacional de Saúde.

$O$ roteiro para as entrevistas tem seis questões e dados pessoais como, o nome da biblioteca onde trabalha, idade, tempo de serviço na função e gênero. As respostas foram gravadas e transcritas integralmente para posterior tratamento, utilizando as figuras metodológicas propostas por LEFÈVRE e LEFÈVRE (2003). 
A fim de expor quantitativamente o total de respostas e o peso relativo de um determinado DSC, são construídos gráficos, do tipo histograma, para cada uma das Idéias Centrais, apresentados como Resultados Quantitativos. 
9 Resultados e Análise 
De posse dos discursos obtidos por gravação das entrevistas e transcritos na íntegra, são procedidas as operações necessárias para a pesquisa com o DSC, com o processamento em separado de cada uma das questões e a utilização do software QualiQuantiSoft.

A análise é feita na resposta de cada indivíduo, às perguntas do Roteiro de Entrevistas (Anexo II), extraídas as Idéias centrais das Expressões-chave (Anexo III) e a posterior construção dos DSCs, um para cada Idéia central, utilizando artifícios de retórica discursiva.

Antecedem a apresentação dos DSCs, quadros e gráficos que revelam também a intensidade, medida pelo peso de cada DSC e representada por percentuais.

São apresentados também os critérios que orientaram a análise para o agrupamento e inserção das Expressões-chave nas Idéias centrais.

Posteriormente é apresentado o Perfil dos Entrevistados com quadros que trazem os percentuais referentes ao sexo, ao tempo na função e à idade; a seguir são apresentadas as análises dos DSCs, separadamente para cada pergunta.

Para a $2^{a}$ e $3^{a}$ perguntas a análise foi feita em conjunto, pois nos dois casos o que se quer saber são os fatores ou situações que afetam o comprometimento organizacional; na $2^{\underline{a}}$ pergunta fatores impeditivos e na $3^{\text {a }}$ fatores e situações que favorecem o comprometimento. 


\subsection{PerfiL dos ENTREVISTAdos}

Foram ouvidos funcionários das equipes das catorze bibliotecas selecionadas, sendo que foi entrevistado pelo menos um funcionário para cada categoria profissional, a dos bibliotecários, dos técnicos e dos básicos em cada uma das catorze bibliotecas. Além desses, dois funcionários ofereceram-se para serem entrevistados, e portanto o número de sujeitos da pesquisa totalizou quarenta e quatro funcionários.

Dos bibliotecários entrevistados, $11,12 \%$ são do sexo masculino e $88,88 \%$ do sexo feminino; para os técnicos os percentuais são de $37,5 \%$ no sexo masculino e 62,5 no sexo feminino. Os básicos estão divididos em $50 \%$ para cada sexo, no entanto, observa-se entre os entrevistados que há predominância do sexo feminino entre os bibliotecários e técnicos.

QUADRO 1: PERFIL dos ENTREVISTAdos QUANTO AO SEXO

\begin{tabular}{|c|c|c|c|c|c|c|}
\hline & \multicolumn{2}{|c|}{ MASC } & \multicolumn{2}{|c|}{ FEM } & \multicolumn{2}{|c|}{ Total } \\
\hline & $\mathbf{N}$ & $\%$ & $\mathbf{N}$ & $\%$ & $\mathbf{N}$ & $\%$ \\
\hline BIBLIOTECÁRIOS & 2 & 11.12 & 16 & 88.88 & 18 & 100 \\
\hline TÉCNICOS & 6 & 37.5 & 10 & 62.5 & 16 & 100 \\
\hline BÁSICOS & 5 & 50 & 5 & 50 & 10 & 100 \\
\hline TOTAL & 13 & 29.54 & 31 & 70.46 & 44 & 100 \\
\hline
\end{tabular}

O número total dos entrevistados foi dividido em três grupos para o tempo de serviço na função; para aqueles que tem uma experiência de 
trabalho de até dois anos, os percentuais são de $11,12 \%$ para os bibliotecários, 6,25\% para os técnicos sendo que não há básicos nesta categoria. No grupo que tem de 2 anos até dez anos na função, bibliotecários somam $16,67 \%$, técnicos $37,5 \%$ e básicos $40 \%$. Entre aqueles que têm mais de dez anos na função, os bibliotecários são representados por $72,21 \%$, os técnicos por $56,25 \%$, e os básicos apresentam o percentual de $60 \%$ para esse grupo de funcionários com mais de 10 anos na função.

QUADRO 2: PERFIL dos ENTREVISTAdOS QUANTO AO TEMPO NA FUNÇÃo

\begin{tabular}{|c|c|c|c|c|c|c|c|c|}
\hline & \multicolumn{2}{|c|}{$<2$ anos } & \multicolumn{2}{|c|}{$>2$ e $<10$} & \multicolumn{2}{|c|}{+ de 10 anos } & \multicolumn{2}{|c|}{ Total } \\
\hline & $\mathbf{N}$ & $\%$ & $\mathbf{N}$ & $\%$ & $\mathbf{N}$ & $\%$ & $\mathbf{N}$ & $\%$ \\
\hline BIBLIOTECÁRIOS & 2 & 11.12 & 3 & 16.67 & 13 & 72.21 & 18 & 100 \\
\hline TÉCNICOS & 1 & 6.25 & 6 & 37.5 & 9 & 56.25 & 16 & 100 \\
\hline BÁsICOS & - & - & 4 & 40 & 6 & 60 & 10 & 100 \\
\hline TOTAL & 3 & 6.82 & 13 & 29.54 & 28 & 36.36 & 44 & 100 \\
\hline
\end{tabular}

Quanto à idade, bibliotecários somam $11,12 \%$ e técnicos 6,25\% entre aqueles que tem até 30 anos. Na faixa de 30 até 45 anos, os bibliotecários são $55,56 \%$, os técnicos $62,5 \%$ e os básicos dividem-se igualmente entre esta faixa e a de 45 anos e mais, onde os bibliotecários somam 33,32\% e os técnicos $31,25 \%$. Observa-se que entre os entrevistados, o percentual para funcionários com idade abaixo de 30 anos é de 6,82\% e entre esses, nenhum é de nível básico. 
QUADRO 3: PERFIL DOS ENTREVISTADOS QUANTO À IDADE

\begin{tabular}{|c|c|c|c|c|c|c|c|c|}
\hline & \multicolumn{2}{|c|}{ Até 30 anos } & \multicolumn{2}{|c|}{ de $30 a<45$} & \multicolumn{2}{|c|}{$45 e+$ anos } & \multicolumn{2}{|c|}{ Total } \\
\hline & $\mathbf{N}$ & $\%$ & $\mathbf{N}$ & $\%$ & $\mathbf{N}$ & $\%$ & $\mathbf{N}$ & $\%$ \\
\hline BIBLIOTECÁRIOS & 2 & 11.12 & 10 & 55.56 & 6 & 33.32 & 18 & 100 \\
\hline TÉCNICOS & 1 & 6.25 & 10 & 62.5 & 5 & 31.25 & 16 & 100 \\
\hline BÁSICOS & - & - & 5 & 50 & 5 & 50 & 10 & 100 \\
\hline TOTAL & 3 & 6.82 & 25 & 56.82 & 16 & 36.36 & 44 & 100 \\
\hline
\end{tabular}


9.2 APRESENTAÇÃo E ANÁLISE dOS RESULTADOS QUALI-QUANTITATIVOS

\section{$1^{\text {a }}$ Pergunta}

\section{A seu ver o que é comprometimento organizacional?}

QUADRO1 - SÍNTESE DAS IDÉIAS CENTRAIS PARA A 1르 PERGUNTA

\begin{tabular}{|c|l|c|c|}
\hline \multicolumn{1}{|c|}{ Idéias centrais } & N & $\%$ \\
\hline A & $\begin{array}{l}\text { Ter conhecimento e concordância com os objetivos da } \\
\text { instituição }\end{array}$ & 25 & 36,76 \\
\hline B & Ter o comprometimento como atitude & 2 & 2,94 \\
\hline C & Gostar do ambiente de trabalho e do trabalho que executa & 3 & 4,41 \\
\hline D & $\begin{array}{l}\text { Saber que seu papel e as atividades que executa são } \\
\text { importantes para a instituição }\end{array}$ & 10 & 14,71 \\
\hline E & $\begin{array}{l}\text { Reconhecer seu dever e sua responsabilidade com a a } \\
\text { qualidade das atividades desenvolvidas na instituição }\end{array}$ & 16 & 23,53 \\
\hline F & "Vestir a camisa" da instituição & 12 & 17,65 \\
\hline TOTAL DE RESPOSTAS DA PERGUNTA & $\mathbf{6 8}$ & $\mathbf{1 0 0}$ \\
\hline
\end{tabular}

Gráfico 1 - Percentual de Idéias Centrais Relativo À 1a Pergunta A seu Ver o QUE É COMPROMETIMENTO ORGANIZACIONAL?

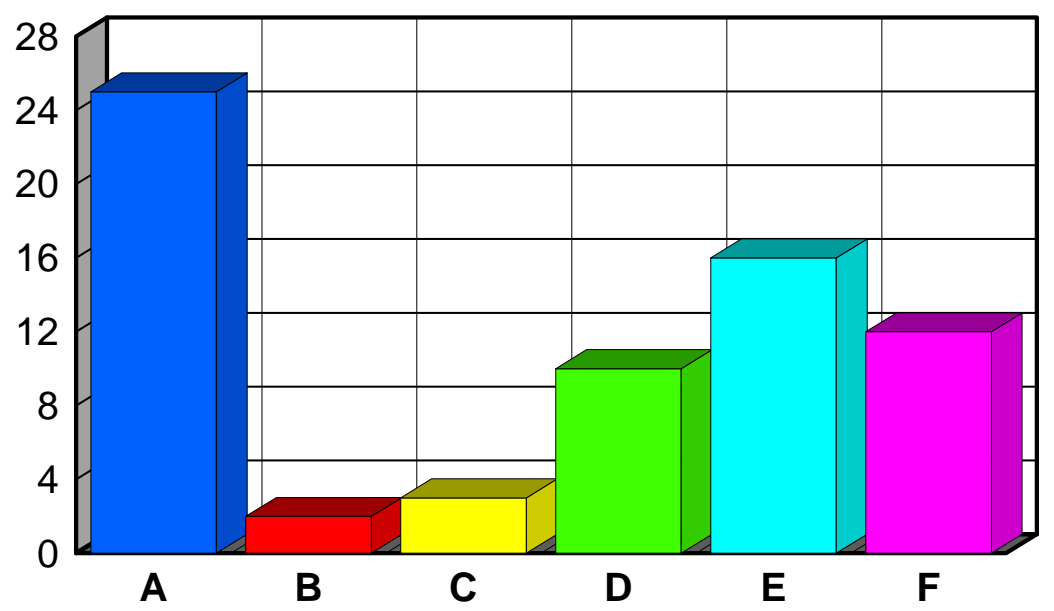




\section{Critérios utilizados para a inserção nas idéias centrais}

\section{A - Ter conhecimento e concordância com os objetivos da instituição \\ É mencionada a existência e o conhecimento da missão, valores e objetivos ou metas da instituição ou de parte dela.}

B - Ter o comprometimento como atitude

O comprometimento é relatado como postura pessoal e presente em outros aspectos da vida

C - Gostar do ambiente de trabalho e do trabalho que executa

Há identificação e gosto pela atividade desempenhada, pelos processos de trabalho e o ambiente onde isso ocorre.

D - Saber que seu papel e as atividades que executa são importantes para a instituição

Reconhece-se como parte da instituição e o seu trabalho como resultado que gera para essa instituição

E - Reconhecer seu dever e sua responsabilidade com a qualidade das atividades desenvolvidas na instituição

Noção de dever e responsabilidade e referência à qualidade do serviço prestado

F - "Vestir a camisa" da instituição

A inserção e o engajamento do funcionário na instituição

\section{A - Ter conhecimento e concordância com os objetivos da instituição}

\section{DSC}

Comprometimento organizacional é quando o funcionário ou as equipes de funcionários inseridos na biblioteca, na Unidade e mesmo na Universidade têm interesse, conhecem, compreendem o negócio, e assumem como seus, os valores, a missão da organização, seus objetivos, suas diretrizes e suas políticas, com as normas, as leis e as regras definidas para a organização como um todo. Em concordância com isso, e afinados com os objetivos da instituição, os funcionários têm comportamentos, atitudes e realizam suas ações, dispostos a trabalhar sabendo o que a instituição espera deles e com o compromisso de obter os resultados que a instituição estipulou para alcançar suas metas e seus objetivos e até superá-Ios. 


\title{
B - Ter o comprometimento como atitude
}

\section{DSC}

Pessoas que são comprometidas com o trabalho também são comprometidas com outras áreas de sua vida, comprometido primeiro com você mesma. No trabalho sempre é exigido comprometimento dos funcionários e ultimamente isso vem sendo bastante falado, tem gente que já é comprometido mas não sabia exatamente o que significava isso.

\section{C - Gostar do ambiente de trabalho e do trabalho que executa}

\section{DSC}

Está relacionado a vários aspectos que envolvem o indivíduo com seu ambiente de trabalho, fatores ligados à motivação, ao comprometimento com o trabalho, ao ambiente na equipe e gostar do trabalho; o grau de envolvimento deve ser grande.

\section{D - Saber que seu papel e as atividades que executa são importantes para a instituição}

\section{DSC}

\begin{abstract}
Eu conheço o que faço e sei o que fazer prá cumprir meu papel na instituição, com capacidade e a responsabilidade de desempenhar bem o trabalho, com a perspectiva de atingir um objetivo que a Unidade definiu e que você vai ajudar a realizar da melhor forma possível, com consciência sobre a importância desse trabalho para a organização, de modo a somar com todo o resto e ajudar a instituição a cumprir o seu papel dentro daquilo. Comprometimento tem a ver com entendimento que ele tem da importância dele dentro da instituição, ter o conhecimento prévio das atividades que vai desenvolver e ter muita consideração pela instituição onde atua, sabendo que tudo o que faz significa para a instituição, e é capaz de responder com trabalho e cada um deve saber qual é o seu papel e se comprometer com ele.
\end{abstract}




\section{E - Reconhecer seu dever e sua responsabilidade com a qualidade das atividades desenvolvidas na instituição}

DSC

Eu me comprometo fazendo o meu serviço direito, dentro da minha capacidade eu tento resolver tudo. Prá mim trabalho é trabalho e quem é comprometido não está para brincadeira, leva o trabalho a sério, entende que tem um trabalho que depende dele e ele deve isso pra instituição; é assumir de maneira integral suas atividades e as responsabilidades que são designadas, realizar o trabalho com qualidade, responsabilidade e dedicação e não importa de se é um trabalho complexo ou não.

\section{F - "Vestir a camisa" da instituição}

\section{DSC}

Comprometimento é o que antes a gente falava de vestir a camisa do lugar de trabalho, da Unidade, estar engajada em todas as atividades do local de trabalho, comprometer-se com a organização, com as tarefas, com as coisas do trabalho, inserir-se no contexto; vestir a camisa mesmo. É um forte envolvimento com tudo o que diz respeito ao trabalho e ao lugar onde trabalha e à dedicação do funcionário para a instituição.

Para qualquer uma das Idéias centrais apresentadas e quaisquer que sejam as razões verbalizadas pelos sujeitos de pesquisa, estão no escopo do que BECKER (1992) chama de diversas dimensões do comprometimento, os componentes presentes no vínculo psicológico entre o indivíduo e a organização.

O vínculo declarado de comprometimento com os pressupostos institucionais, como a missão, os valores e os objetivos, e a disposição do funcionário para reconhecê-los, aparece em trechos do DSC,

“... em concordância com isso, e afinados com os objetivos da instituição,

os funcionários têm comportamentos, atitudes e realizam suas ações, dispostos a trabalhar sabendo o que a instituição espera deles e com o compromisso de obter os resultados que a instituição estipulou..." 
As bibliotecas universitárias, assim como outras organizações, incorporaram em suas estruturas, e portanto têm presente em suas missões, tanto quanto possível, as características de uma organização que busca flexibilizar-se e adaptar-se às premissas das modernas estruturas organizacionais, fenômeno que vem sendo registrado na literatura, como em BOWERS (1996), que recomenda fatores que devem permear as estruturas organizacionais da bibliotecas universitárias: a maior flexibilidade; a redução da burocracia; equipes treinadas para a tomada de decisão; o aprimoramento da prestação de serviços com qualidade e orientados para a satisfação dos usuários; a adoção de um modelo de organização da aprendizagem; a promoção da integração, trabalho em equipe, comunicação e satisfação no trabalho.

Três Idéias Centrais da 1a Pergunta:

Ter conhecimento e concordância com os objetivos da instituição,

Saber que seu papel e as atividades que executa são importantes para a instituição, e

"Vestir a camisa" da instituição, como um sinônimo de engajamento, representam $77,94 \%$ do total para a pergunta, e dizem respeito aos conceitos de papeis e de engajamento na instituição, assumidos como importantes, para os sujeitos de pesquisa.

Chamam a atenção os percentuais de $36,76 \%$, o maior, para a explicação do Comprometimento organizacional pela Idéia central Ter conhecimento e concordância com os objetivos da instituição, 
enquanto que o menor, $4,41 \%$, refere-se a Gostar do ambiente de trabalho e do trabalho que executa.

Os motivos declarados para o Comprometimento organizacional referem-se em maior percentual àqueles que dizem respeito à instituição e seus pressupostos, em comparação com motivos pessoais com relação ao trabalho e ao ambiente, ficando claro que os respondentes "olham" mais para a instituição do que para os aspectos de sua inserção profissional.

$\mathrm{Na}$ Idéia central Ter o comprometimento como atitude, o compromisso antecede as relações com a organização, estando presente em aspectos da vida do indivíduo, mesmo fora da instituição na qual desenvolve suas atividades; isso transposto para dentro da instituição assume perspectivas atitudinais, dando conta de tudo o que o indivíduo traz consigo para a situação de trabalho, relacionado ao enfoque afetivo do comprometimento organizacional, principal objeto de estudo de MOWDAY, PORTER e STEERS, na década de 80.

A qualidade como um atributo de produtos e serviços que atendem às necessidades dos usuários, é assumida como responsabilidade dos sujeitos de pesquisa e demonstra a apreensão do que os usuários significam para prestação dos serviços, e principalmente na demanda de desenvolvimento de novos produtos.

HERNON, NITECKI e ALTMAN (2005) consideram um indicador da satisfação dos usuários, a utilização efetiva dos serviços, que conferem a esses usuários, um papel ativo no processo de transferência da informação, ao considerá-los co-produtores do serviço e de sua qualidade. 


\section{$2^{\text {a }}$ Pergunta}

Vamos falar um pouco de comprometimento. Que situaç̃es ou fatores você acha que impedem um indivíduo de se comprometer com o trabalho, no ambiente das bibliotecas?

QuAdRo 2 - SínTESE dAS IDÉIAS CENTRAIS PARA A 2a PERGUNTA

\begin{tabular}{|c|l|c|c|}
\hline & \multicolumn{1}{|c|}{ Idéias centrais } & $\mathrm{N}$ & $\%$ \\
\hline A & $\begin{array}{l}\text { Insuficiência de conhecimento e informações para o } \\
\text { desempenho da atividade, de equipamentos e de clareza } \\
\text { do papel que deve ser desempenhado }\end{array}$ & 18 & 24,00 \\
\hline B & Desrespeito & 2 & 2,67 \\
\hline C & $\begin{array}{l}\text { Injustiça no tratamento pessoal ou nas oportunidades } \\
\text { oferecidas }\end{array}$ & 11 & 14,67 \\
\hline D & $\begin{array}{l}\text { Falta de incentivo ou de reconhecimento pelo trabalho } \\
\text { executado }\end{array}$ & 16 & 21,33 \\
\hline E & $\begin{array}{l}\text { Insatisfação com o trabalho que executa ou com o } \\
\text { ambiente de trabalho }\end{array}$ & 21 & 28,00 \\
\hline F & Ausência de metas para a carreira. & 4 & 5,33 \\
\hline G & Relações conflituosas com as chefias. & 2 & 2,67 \\
\hline H & O caráter do funcionário & 1 & 1,33 \\
\hline TOTAL DE RESPOSTAS DA PERGUNTA & $\mathbf{7 5}$ & $\mathbf{1 0 0}$ \\
\hline
\end{tabular}

Gráfico 2- Percentual de IdÉias Centrais Relativo À 2 ${ }^{\text {a }}$ Pergunta Vamos falar UM POUCO DE COMPROMETIMENTO. QUE SITUAÇÕES OU FATORES VOCÊ ACHA QUE IMPEDEM UM INDIVÍDUO DE SE COMPROMETER COM O TRABALHO, NO AMBIENTE DAS BIBLIOTECAS?

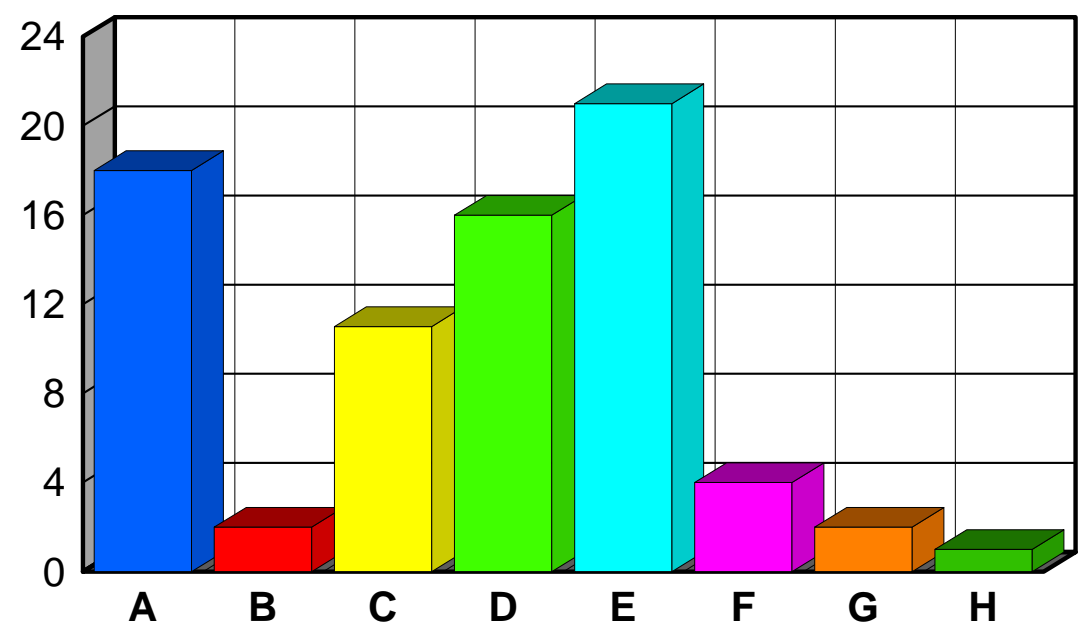


Critérios utilizados para a inserção nas idéias centrais

A - Insuficiência de conhecimento e informações para o desempenho da atividade, de equipamentos e de clareza do papel que deve ser desempenhado

Falhas ou faltas sentidas na infra-estrutura necessária para o trabalho, como equipamentos, local apropriado ou mesmo informações essenciais para sua execução.

B - Desrespeito

A importância do respeito ou a falta dele são explicitadas no discurso.

C - Injustiça no tratamento pessoal ou nas oportunidades oferecidas

Sempre que aparecem as questões de diferenças feitas entre os funcionários, na maneira de tratar ou nas oportunidades de participação

D - Falta de incentivo ou de reconhecimento pelo trabalho executado

Ausência do retorno dado ao funcionário, pelo trabalho executado, a contento ou não.

E - Insatisfação com o trabalho que executa ou com o ambiente de trabalho

Verbalizações a respeito de gostar ou não do trabalho que executa ou do ambiente onde trabalha.

F - Ausência de metas para a carreira

O plano de carreira na Universidade ou seus aspectos são abordados.

G - Relações conflituosas com as chefias

Quando são referidas características das chefias, tidas como prejudiciais ao comprometimento.

H - O caráter do funcionário

É referida particularidade do caráter.

\section{A - Insuficiência de conhecimento e informações para o desempenho da atividade, de equipamentos e de clareza do papel que deve ser desempenhado}

\section{DSC}

Não saber o que está fazendo, pra que está fazendo aquilo, fazer parte de um trabalho mas não saber o que é que aquilo vai completar lá no fim, não ser informado direito, você faz mas não sabe bem pra que e tem medo de errar, ou foi mal orientado ou é novo e ainda não segue bem as regras. Faltar capacitação pra resolver os problemas técnicos, faltar conhecimento e compreensão do trabalho que deve ser feito ou não entender o que está fazendo, afinal, ninguém se compromete com o que não entende. Não ser bem aceito na instituição, ou o chefe não ser claro com ele, não expor todas as regras e depois que alguma coisa não dá certo, cobrar; não tendo clareza dos papeis de cada um.Dá insatisfação e a insegurança dentro do ambiente de trabalho, impede o comprometimento, porque você interage com seus colegas o tempo todo, muito 
do seu trabalho depende do outro e é insegurança em relação ao outro, em relação ao ambiente mesmo de trabalho: a falta de condições de trabalho, o lugar que não é adequado ou os instrumentos e equipamentos que não estão em condição ou que faltam.

\section{B - Desrespeito}

\section{DSC}

Desde uma coisa subjetiva como o respeito pois a falta de respeito acaba com o comprometimento de qualquer um quando o funcionário se sente de alguma forma desrespeitado ou menosprezado. Afinal você trata seus colegas de profissão com respeito e quer também ser tratada com respeito. Claro que dinheiro é bom mas se você ganha bem mas não é respeitado, o que adianta?

\section{C - Injustiça no tratamento pessoal ou nas oportunidades oferecidas}

\section{DSC}

Um ambiente de trabalho que faz diferenças entre os direitos dos funcionários ou injustiça, como um funcionário que dedica seu tempo ao trabalho e outros que não fazem isso, mas ninguém fala ou chama a atenção, ou mesmo a empresa não faz sua parte: é um ambiente onde nem todos se dão bem e isso não é bom, pois as regras não são claras e só alguns seguem essas regras e outros são tratados diferente, só determinadas pessoas tem oportunidades, não havendo justiça para se aprimorar, fazer cursos e treinamentos e participação. Uns conseguem mais coisas que outros, podem algumas coisa, tem a preferência da chefia e fazem mais cursos e são privilegiados mas só alguns os outros não podem. A falta de oportunidades de crescimento profissional, ou a mesma oportunidade para todos se desenvolverem tecnicamente, a ausência de abertura e participação com novas idéias dentro da atividade que desenvolve. O indivíduo não se sente parte integrante da organização para a qual trabalha e quando falta alguma coisa prá pessoa, seja ela material ou do tipo de diferença entre funcionários, ela vai ali faz o que tem que fazer só pra receber o salário; até pode ser que ela goste do que ela faz mas talvez não encontre amparo pra fazer melhor o seu serviço, não sente respaldo prá trabalhar melhor. Isso tudo também é frustrante e ninguém gosta, além de atrapalhar o comprometimento e impedir o bom andamento do grupo todo e do serviço, porque a pessoa sabe que mesmo que se esforçar não vai conseguir nada. Não pode dar moleza, tem que exigir igual de todos e dar as mesmas oportunidades para todos, afinal somos uma equipe e todos devem ter as mesmas obrigações, mesmo nas diferentes atividades. 


\title{
D - Falta de incentivo ou de reconhecimento pelo trabalho executado
}

\author{
DSC
}

\begin{abstract}
Fatores que desgastam o funcionário e o ambiente de trabalho e não levam a nada, como fofoca, falta de estimulo dos chefes, a falta de motivação, falta de incentivo e de reconhecimento por parte de seus superiores e falta de feedback de quem chefia a equipe. Isso é uma forma de falta de reconhecimento e se você não é reconhecido é muito duro, e ninguém fica comprometido, até trabalha contra, pois se os funcionários não são incentivados não querem saber de comprometimento, nem querem ficar naquela biblioteca. Não ter retorno do trabalho que foi entregue, a falta de valorização desse trabalho pelos outros membros da equipe, a falta de incentivo para o crescimento intelectual, incentivo de palavras mesmo, até porque todos nós sabemos que é praticamente impossível o incentivo financeiro; isso vai deixando você desanimado até se descomprometer. O diferencial seria uma palavra de incentivo e de força, pois ouvir que o seu trabalho está bem feito ajuda muuuuito, mas eu sinto que isso não tem sido pra todos e as pessoas vão se sentindo inferiorizadas.
\end{abstract}

\section{E - Insatisfação com o trabalho que executa ou com o ambiente de trabalho}

\section{DSC}

Intriga e confusão no trabalho, desinteresse pela atividade desenvolvida, não gostar do que faz, a responsabilidade que ele não tiver com as atividades que vão ser feitas, como por exemplo informar as pessoas. Isso envolve também o mau relacionamento com as pessoas à sua volta porque não está satisfeita por motivos profissionais ou financeiros ou se não estiver muito satisfeito com o lugar e quiser mudar, isso não é fácil na Universidade, então fica insatisfeito e não dá o seu melhor. Além disso, se não gostar dos colegas também fica chato pois não tem relacionamentos e não tem ambiente. O perfil do funcionário interfere bastante, a pessoa que não faz o que gosta, não tem um prazer, isso já é $80 \%$ para o descomprometimento no desempenho de suas atividades. Quando há conflitos e quando nem todos se dão bem, isso acaba refletido no trabalho e as pessoas trabalham só naquilo que está dentro do perfil delas e não se esforçam para a aprender outras coisas, pois o ambiente não favorece. Equipes com problemas de relacionamento e funcionários que não estão interessados em ser parte integrante daquela equipe prejudicam pela falta de cooperação de todos na mesma medida, só alguns estão dispostos a cooperar para todo o grupo, para a equipe; é um fator bem negativo o ambiente de trabalho ruim, isso afeta todos, não existe interação entre as diversas áreas, há falhas de comunicação. 


\section{F - Ausência de metas para a carreira}

\section{DSC}

Os funcionários do nível técnico nas bibliotecas não tem muitas metas de carreira pra serem alcançadas, vai até ali e parou pois você não pode chegar a uma chefia, não pode ter um cargo e isso não incentiva muito. Na Universidade a política de incentivo para os funcionários não é das melhores, inclusive os critérios de carreira são questionáveis

\section{G - Relações conflituosas com as chefias}

\section{DSC}

Se você tem uma chefia fraca e autoritarismo por parte da direção também impedem que os funcionários se comprometam; os funcionários não se sentem valorizados, porque não são ouvidos.

\section{H - O caráter do funcionário}




\section{$3^{\text {a }}$ Pergunta}

Ao contrário, na sua opinião, que fatores você acha que auxiliariam no comprometimento dos profissionais nas bibliotecas?

QUADRO 3 - SÍNTESE DAS IDÉIAS CENTRAIS PARA A 3ミ PERGUNTA

\begin{tabular}{|c|l|c|c|}
\hline & \multicolumn{1}{|c|}{ Idéias centrais } & $\mathrm{N}$ & $\%$ \\
\hline A & $\begin{array}{l}\text { Ter conhecimento, informações e equipamentos } \\
\text { suficientes para o desempenho da atividade, bem como } \\
\text { clareza do papel que desempenha }\end{array}$ & 9 & 14,06 \\
\hline B & Oferecimento de cursos e treinamentos & 7 & 10,94 \\
\hline C & Gostar do trabalho e do ambiente no qual trabalha & 14 & 21,88 \\
\hline D & $\begin{array}{l}\text { Obter reconhecimento e incentivo pelo trabalho que } \\
\text { executa }\end{array}$ & 16 & 25,00 \\
\hline E & $\begin{array}{l}\text { Justiça e respeito no tratamento pessoal e nas } \\
\text { oportunidades }\end{array}$ & 13 & 20,31 \\
\hline F & Autonomia & 3 & 4,69 \\
\hline G & Existência de carreira & 1 & 1,56 \\
\hline H & Presença de liderança & 1 & 1,56 \\
\hline TOTAL DE RESPOSTAS DA PERGUNTA & $\mathbf{6 4}$ & $\mathbf{1 0 0}$ \\
\hline
\end{tabular}

Gráfico 3 - Percentual de idéias centrais relativo à 3a Pergunta Ao CONTRÁRIO, NA SUA OPINIÃO, QUE FATORES VOCÊ ACHA QUE AUXILIARIAM NO COMPROMETIMENTO DOS PROFISSIONAIS NAS BIBLIOTECAS?

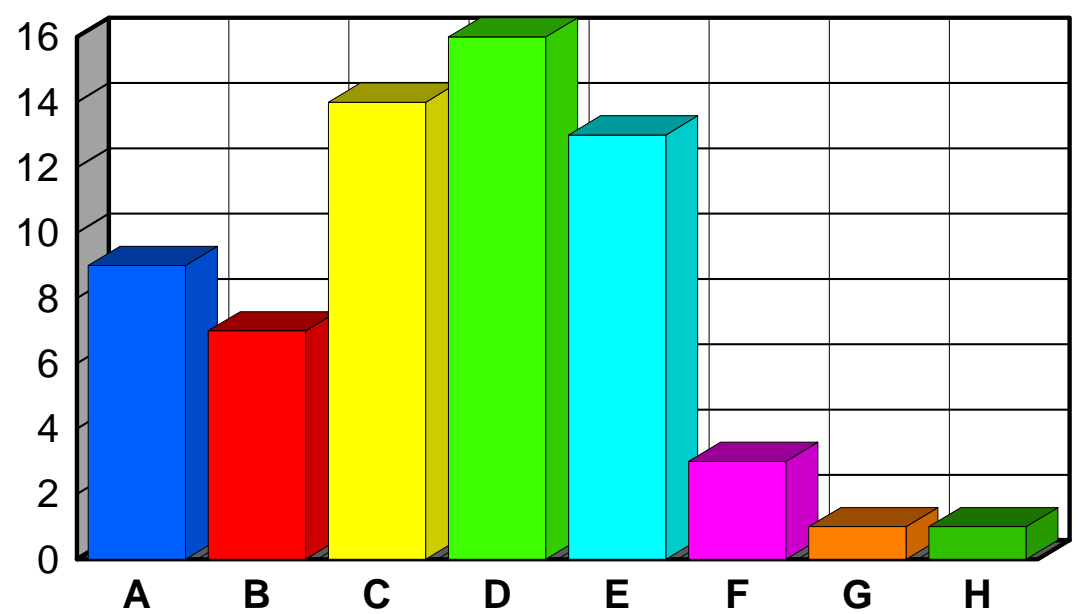


Critérios utilizados para a inserção nas Idéias centrais A - Ter conhecimento, informações e equipamentos suficientes para o desempenho da atividade, bem como clareza do papel que desempenha

A presença e suficiência das informações e equipamentos necessários à execução do trabalho e a clareza do papel desempenhado.

B - Oferecimento de cursos e treinamentos

As oportunidades oferecidas para participar de treinamentos e cursos relacionados com o trabalho, ou outras ações de capacitação.

\section{C - Gostar do trabalho e do ambiente no qual trabalha}

Gosto pela atividade e pelo ambiente onde trabalha.

\section{D - Obter reconhecimento e incentivo pelo trabalho executado}

São abordados os elogios, as críticas, o incentivo, o reconhecimento e manifestações motivadoras, pelos chefes e colegas de trabalho.

\section{E - Justiça e respeito no tratamento pessoal e nas oportunidades}

É referida a justiça e igualdade no tratamento pessoal, pelos chefes e entre os membros da equipes, com as mesmas chances de participação nas oportunidades de crescimento profissional.

\section{F - Autonomia}

Importância dada a uma certa autonomia para a realização de tarefas da rotina.

\section{G - Existência de carreira}

É abordado o plano de carreira que atenda a bibliotecários, técnicos e básicos como oportunidade para o alcance de cargo.

\section{H - Presença de liderança}

O papel do líder.

\section{A - Ter conhecimento, informações e equipamentos suficientes para o desempenho da atividade, bem como clareza do papel que desempenha}

\section{DSC}

São aqueles fatores que eu citei: os equipamentos, a clareza da importância do que é o papel de cada profissional, independente do nível em que está inserido (básico, técnico e superior). Claramente estabelecidos os papéis de cada um e com as informações necessárias, tudo isso ajuda o funcionário a se comprometer, pois faz com que o indivíduo se sinta engajado na equipe, não só na equipe da biblioteca, na faculdade inteira. Saber que o que ele faz no dia a dia faz parte de uma outra coisa maior, saber que a parte que ele faz é importante e que sem ela 
não se conseguiria o todo. Quando os objetivos são passados, as atividades são explicadas e são claras, e são bem ensinadas as coisas que devem ser feitas, você está capacitado, bem informado e vai fazer direito; como eu que aprendi o que faço hoje

\section{B - Oferecimento de cursos e treinamentos}

\section{DSC}

Treinamento é o melhor jeito de comprometer as pessoas, quanto mais treinado o funcionário melhor ele vai responder pro trabalho e isso em todos os níveis, quando aprende direito gosta mais de fazer. Quando é oferecida capacitação e incentivo para educação continuada, para os novos desafios, treinar para as metas a serem atingidas, com cursos e programas para o auto-desenvolvimento, confraternizações, enfim é o investimento em treinamento e capacitação pra que o funcionário tenha segurança do que faz.

\section{C - Gostar do trabalho e do ambiente no qual trabalha}

\section{DSC}

Fatores como bom ambiente de trabalho, e como eu vou dizer... o todo se dá bem, é isso, é o ambiente de trabalho em si, com as relações boas entre todos os funcionários, entre os pares e também com as chefias, na amizade e apoio, principalmente nas bibliotecas, onde bibliotecários e técnicos trabalham bastante juntos e tem um ambiente harmonioso; é essa coisa de equipe porque hoje só se trabalha em equipe, e você faz parte de uma equipe onde todos se conhecem e mesmo com os defeitos de cada um há respeito, você já está acostumado àquela equipe, cada um já sabe o que esperar e se você der sorte de estar numa boa equipe, uma equipe afinada então é uma maravilha, pois tem um bom ambiente de trabalho. Quem faz o que gosta também é mais fácil de se comprometer, gostar do trabalho e gostar do pessoal que trabalha junto, do ambiente que aliás pode até ser competitivo mas tem que ser ético, pois ambiente de amizade também é um incentivo e compromete mais e quando se está feliz então se compromete com aquilo que faz e gosta do lugar e do ambiente, logo, isso favorece e já ti estimula a buscar mais.

\section{D - Obter reconhecimento e incentivo pelo trabalho executado}

\section{DSC}

Um ambiente que valoriza, não só pra bibliotecários ou só pra quem tem chefia, mas pr' um todo. Você valoriza a pessoa, ela se envolve mais com o que vai fazer e se compromete; tem que ser assim, com coisas que fazem um bibliotecário se comprometer, fazem um básico e um técnico, pois todos gostam de reforço positivo e elogios ou críticas, com o apoio da chefia. As críticas são para melhorar não pra acabar com o funcionário, se você é elogiado sempre vai 
procurar fazer melhor e acho que um trabalho bem feito deve ser sempre reconhecido, é o feedback positivo, ou mesmo um negativo, mostrando que tem alguém ti ajudando a fazer o trabalho, ti dando um retorno que se deve dar pro trabalho realizado pois às vezes o funcionário trabalha um tempão sem que ninguém diga a ele como está seu trabalho, ou ainda por fazer o que sempre faz ou uma coisa nova. Uma palavra é sempre bem-vinda e ouvir outras pessoas da organização dizerem que o que você fez está bem feito é muito importante e você se sente seguro com o que faz, não só na biblioteca, mas na Unidade, afinal os serviços prestados aqui são para a coletividade e para todos da Unidade.

\section{E - Justiça e respeito no tratamento pessoal e nas oportunidades}

DSC

Tem que tratar todos iguais e se a biblioteca trata bem todos os seus funcionários com as mesmas chances para todos aprenderem e sabendo o que cada um precisa pra desenvolver melhor seu trabalho, o funcionário sente que tem oportunidades para fazer o que aparece, como cursos e eventos e que têm a mesma chance de crescer. Assim, ele responde melhor quando precisam dele e todos se sentem fazendo parte da equipe, sabendo que podem crescer e que todos têm o mesmo respeito do chefe, mesmo que isso não traga uma promoção, pois a participação de todos de maneira igual nos cursos e palestras incentiva todos e acaba anulando quem não está nem aí. A participação de todos, e o bom relacionamento, também o incentivo para o estudo e para as oportunidades que sempre surgem de se reciclar, de aprender e crescer, afinal todos têm oportunidades de compartilhamento das informações.

\section{F - Autonomia}

\section{DSC}

Certa autonomia pra resolver os assuntos do cotidiano é importante, faz bem e também ajudam a motivar.

\section{G - Existência de carreira}

\section{DSC}

... um plano de carreira, mas que fosse bom prá todos. Ser bem avaliado, progredir na carreira ... compromete, faz vestir a camisa ...

\section{H - Presença de liderança}

\section{DSC}

A liderança é fundamental e o líder tem que estar sempre presente e fazer seu papel. 
Os fatores ou situações apontados como impeditivos ao comprometimento, referem-se na sua maioria, à falta de materiais ou falhas no relacionamento ou tratamento pessoal, e são referidos os equipamentos, as informações, as definições de papeis, o respeito, as relações com as chefias, a justiça, as oportunidades e o reconhecimento pelo trabalho executado.

As Idéias centrais para essas opiniões, representam 93,34\% das 75 respostas e estão presentes nos trechos de DSCs:

Das chefias é preciso apoio e esclarecimentos pois se não tiver essas coisas básicas, ninguém vai se comprometer porque vai correr o risco de não ter nem como desenvolver direito o seu trabalho e desconhecerem o que seu trabalho representa no todo da organização e em que parte está inserido.

... a falta de respeito acaba com o comprometimento de qualquer um quando o funcionário se sente de alguma forma desrespeitado ou menosprezado.

... tem que exigir igual de todos e dar as mesmas oportunidades para todos, afinal somos uma equipe e todos devem ter as mesmas obrigações.

Não ter retorno do trabalho que foi entregue, a falta de valorização desse trabalho pelos outros membros da equipe, a falta de incentivo para o crescimento intelectual, incentivo de palavras mesmo...

... então fica insatisfeito e não dá o seu melhor. Além disso, se não gostar dos colegas também fica chato pois não tem relacionamentos e não tem ambiente. ... uma chefia fraca e autoritarismo por parte da direção também impedem que os funcionários se comprometam uma chefia fraca e autoritarismo por parte da direção também impedem que os funcionários se comprometam

No entanto, ao serem perguntados sobre fatores que auxiliam no comprometimento, não são indicados o respeito e as boas relações com as chefias, mas os sujeitos de pesquisa referem-se principalmente ao 
conhecimento e equipamentos adequados, ao gosto pelo trabalho e pelo ambiente, ao reconhecimento e incentivo e à justiça nas oportunidades, e ainda assim essas Idéias centrais somam $81,25 \%$ das 64 respostas para a pergunta, enquanto que a Idéia central Presença de liderança, que aborda relacionamento e papel do líder, representa apenas 1,56\% das respostas e tem o DSC:

A liderança é fundamental e o líder tem que estar sempre presente e fazer seu papel

A falta ou inadequação sentida nos equipamentos e instrumentos essenciais ao trabalho, afetam diretamente a consecução e a qualidade dos serviços prestados na biblioteca, para os quais, há uma avaliação por parte dos usuários, que acontece simultaneamente ao uso.

SANTOS, FACHIN e VARVAKIS (2003) nomeiam as características principais dos serviços: a intangibilidade, a simultaneidade entre produção e consumo e a participação do cliente/usuário; os autores enfatizam que a participação do usuário no processo de produção do serviço faz ressaltar a importância da gestão dos processos de serviços, para a qual existe o fator da qualidade pretendida.

As idéias centrais que tratam de relacionamentos, de ambiente de trabalho e do "gostar " ou não do trabalho propriamente dito,

- Desrespeito

- Injustiça no tratamento pessoal ou nas oportunidades oferecidas 
- Falta de incentivo ou de reconhecimento pelo trabalho executado

- Insatisfação com o trabalho que executa ou com o ambiente de trabalho

- Relações conflituosas com as chefias

remetem às relações no trabalho ou às situações nas quais o relacionamento afeta a disposição para o comprometimento.

O trabalho é importante no provimento das satisfações humanas, ... os elementos formais - estrutura administrativa e o informais - relacionamento humano, que emerge das experiências do dia-a-dia, integram-se para produzir o padrão real de relacionamento na organização: como o trabalho é verdadeiramente executado e quais as regras comportamentais implícitas que governam os contatos entre as pessoas - esta é a estrutura de contatos e comunicações humanas a partir da qual os problemas de política de pessoal e de tomada de decisões podem ser compreendidos e tratados..." (COSTA, 2002, p. 21).

KOTLER (1998, p. 426) ao abordar a satisfação de funcionários, pondera que as empresas de serviços excelentemente administradas acreditam que as relações com os funcionários refletirão sobre as relações com os consumidores e recorre a ROSENBLUTH e PETERS para ir além; “... os funcionários das empresas, não os consumidores, precisam sentir-se o número um se ela espera satisfazer verdadeiramente seus clientes." 
Para BUENO (2002) o comprometimento das pessoas com a organização tem início com a valorização a elas atribuída e afirma que funcionários comprometidos levarão a empresa a alcançar a produtividade e qualidade, dando 0 , melhor de si e possivelmente, sem a necessidade de supervisão direta.

A organização composta por pessoas que trazem consigo, suas necessidades, potencialidades e limitações, deve ter uma visão integral do indivíduo, para assim compreender em que medida, ela e os grupos de indivíduos possam integrar-se também na busca dos objetivos e de uma boa relação entre esses grupos e a empresa.

O DSC da Idéia central Ausência de metas para a carreira refere-se a aos objetivos relacionados à profissão, representados por 5,33\% das respostas:

Os funcionários do nível técnico nas bibliotecas não tem muitas metas de carreira pra serem alcançadas, vai até ali e parou pois você não pode chegar a uma chefia, não pode ter um cargo e isso não incentiva muito. Na Universidade a política de incentivo para os funcionários não é das melhores, inclusive os critérios de carreira são questionáveis...

É referida a impossibilidade de ocupação de um cargo, com seus aspectos funcionais, os relativos às tarefas que desempenha e os hierárquicos, que referem-se à posição ocupada na biblioteca.

Ao adotarmos o que pensa THÉVENET (1992), para quem que o comprometimento do indivíduo existe quando existem também a adesão e as oportunidades, pois o indivíduo retira alguma coisa da sua relação com a 
organização, é possível analisar a relação dessa Idéia central com Justiça e respeito no tratamento pessoal e nas oportunidades, referida como fator que favorece o Comprometimento organizacional, com maior percentual $(20,31 \%)$ 


\section{$4^{\mathrm{a}}$ Pergunta}

Nós os profissionais das bibliotecas da USP, nas três categorias, temos passado por programas de capacitação, não é mesmo? Fale um pouco sobre o que isso significa prá você.

QuAdRo 4 - SínTESE DAS IDÉIAS CENTRAIS PARA A 4a PERGUNTA

\begin{tabular}{|c|l|c|c|}
\hline & \multicolumn{1}{|c|}{ Idéias centrais } & $\mathrm{N}$ & $\%$ \\
\hline A & $\begin{array}{l}\text { Reflete a preocupação do DT/SIBi com a capacitação e } \\
\text { atualização das equipes }\end{array}$ & 10 & 21,28 \\
\hline B & $\begin{array}{l}\text { Proporciona a integração das equipes das bibliotecas do } \\
\text { Sistema e a troca de experiências. }\end{array}$ & 12 & 25,53 \\
\hline C & $\begin{array}{l}\text { São proveitosos para enriquecer o currículo e concorrer ao } \\
\text { Acesso na Carreira }\end{array}$ & 1 & 2,13 \\
\hline D & $\begin{array}{l}\text { Proporcionam as mesmas oportunidades de participação } \\
\text { para as três categorias de profissionais das bibliotecas: } \\
\text { bibliotecários, técnicos e básicos. }\end{array}$ & 14 & 29,79 \\
\hline E & $\begin{array}{l}\text { São bons, mas ainda não são conhecidos os resultados } \\
\text { dessas participações e suas aplicações nas atividades das } \\
\text { bibliotecas. }\end{array}$ & 5 & 10,64 \\
\hline F & $\begin{array}{l}\text { O conhecimento adquirido é importante, mas há } \\
\text { dificuldades para sua aplicação, nas bibliotecas. }\end{array}$ & 5 & 10,64 \\
\hline TOTAL DE RESPOSTAS DA PERGUNTA & $\mathbf{4 7}$ & $\mathbf{1 0 0}$ \\
\hline
\end{tabular}

Gráfico 4 - PeRCENTUAL de IDÉIAs CENTRAis RELATIVo À 4a PERGUNTA Nós os PROFISSIONAIS DAS BIBLIOTECAS DA USP, NAS TRÊS CATEGORIAS, TEMOS PASSADO POR PROGRAMAS DE CAPACITAÇÃO, NÃO É MESMO? FALE UM POUCO SOBRE O QUE ISSO SIGNIFICA PRÁ VOCÊ?

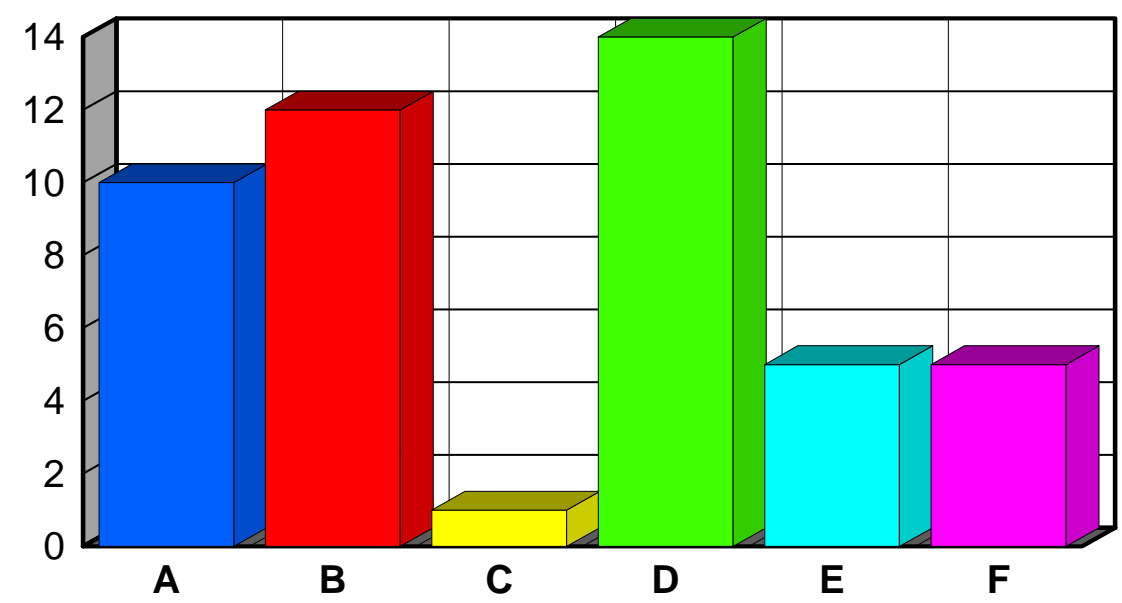




\section{Critérios utilizados para o agrupamento das idéias centrais nas categorias}

\section{A - Reflete a preocupação com a capacitação e atualização das equipes pelo} DTISIBi

Aborda a importância da realização, por proporcionar a oportunidade de aprendizado nos assuntos e temas de interesse de todas as equipes que compõem o Sistema, bem como pela troca de experiências de trabalho vividas pelos colegas.

B - Proporciona a integração das equipes das bibliotecas do Sis-tema e a troca de experiências

Aborda a integração propiciada aos funcionários das bibliotecas do Sistema e de convívio pessoal nos aspectos de situações vividas e satisfação no ambiente de trabalho.

C - São proveitosos para enriquecer o currículo e concorrer ao Acesso na Carreira

É referido um caso de mudança de faixa, pelo Programa de Acesso na Carreira da Universidade

D - Proporcionam as mesmas oportunidades de participação para as três categorias de profissionais das bibliotecas: bibliotecários, técnicos e básicos.

Critérios de participação que incluem todos os funcionários das equipes das bibliotecas: os bibliotecários e os funcionários de níveis técnicos e básicos; com mesmas oportunidades.

E - Ainda não são conhecidos ou sistematizados os resultados dessas participações e suas aplicações ou incrementos nos processos e atividades das bibliotecas

Abordam a necessidade de critérios que avaliem os resultados da capacitação nos processos de trabalho

F - A aplicação dos conhecimentos na prática das bibliotecas não ocorre naturalmente

Referem-se às dificuldades encontradas pelos funcionários capacitados para a aplicação do que aprenderam às possíveis situações para que isso aconteça.

\section{A - Reflete a preocupação com a capacitação e atualização das equipes pelo DT/SIBi}

\section{DSC}

O SIBi assumiu e está preocupado com que todos, todas as pessoas das equipes das bibliotecas se capacitem, que todos os básicos, técnicos e superiores tenham um domínio maior daquilo que realizam; mas não é só no aspecto técnico, esse programa de capacitação proporcionou que as equipes das diferentes bibliotecas do Sistema se integrassem num Sistema mesmo; há troca de experiências, todos ganham com isso e é muito importante que os 
funcionários de uma unidade saibam do trabalho nas outras unidades. Que contato a gente teria com outros campus, se não for quando se faz algum trabalho junto? Quando todos que fazem a mesma atividade e se juntam aparecem coisas muito interessante, não é só como se dessem apostilas pra você ler , são cursos sobre alguma técnica, cursos para serem aplicados no dia a dia, são palestras ou outros cursos que falam de RH e significam muito. É realmente importante, é sempre uma coisa muito legal, tenho aprendido muito e acho que são imprescindíveis porque treinamento é sempre bom, e a capacitação ti dá recursos pra melhorar na profissão, reforçando o comprometimento.

\section{B - Proporciona a integração das equipes das bibliotecas do Sistema e a troca de experiências}

DSC

Essa atual administração do SIBi tem desempenhado um papel importante no
Sistema, porque possibilita a integração com outras pessoas, dos outros modelos
de bibliotecas do SIBi que são mais ou menos parecidas, mas acaba conhecendo
o ambiente de trabalho do outro. O bom mesmo é a integração dos profissionais
que vão fazer para que tenhamos uma visão sistêmica. Eu tenho achado ótimo
pois além de serem ótimos no treinamento dos profissionais para a reciclagem
de conhecimentos e para novos conhecimentos é a oportunidade de convivência
e acho que não tem porque não conhecer melhor o que é uma biblioteca e se
comprometer, acho que tudo é muito bom. Só a integração que isso proporciona
já vale, sempre que tiver quero ir.

\section{C - São proveitosos para enriquecer o currículo e concorrer ao Acesso na Carreira}

\section{D - Proporcionam as mesmas oportunidades de participação para as três categorias de profissionais das bibliotecas: bibliotecários, técnicos e básicos}

\section{DSC}

Acho os cursos muito válidos e importantes, dão oportunidade de treinamento para as três categorias; é uma preocupação não só com as bibliotecárias, mas com todos que trabalham na biblioteca e são a equipe, composta de 
bibliotecários, técnicos e básicos, todos tem que ser convidados para os cursos, como são agora pois tem sido ótimo. Antes só bibliotecários iam fazer cursos, só tinha cursos com matérias de biblioteconomia, os técnicos e básicos se sentiam meio excluídos, e chegavam na biblioteca dizendo o que era pr'os outros fazerem e isso não é a mesma coisa que você mesmo ir fazer o curso. Há muitos elogios, principalmente os técnicos e básicos que agora tem essa oportunidade, afinal é uma inovação a participação de todos que compõem as equipes, é muito democrático e inclusivo, é a nossa oportunidade prá se manter atualizado, para todos os funcionários igualmente. Conversei com outros técnicos de outras bibliotecas que acham muito importante que continue, com todos participando, pois significam oportunidades para os funcionários do sistema aprenderem coisas novas e é bem motivador, pois todos sabem que poderão freqüentar; valoriza o profissional e atende as necessidades da biblioteca, principalmente do SDG. Tinha sim que ter treinamento para todos os níveis de funcionários, é um momento muito importante, para todos os funcionários igualmente, todos recebem o mesmo material e as mesmas aulas para as três categorias, é maravilhoso.

\section{E - Ainda não são conhecidos ou sistematizados os resultados dessas participações e suas aplicações ou incrementos nos processos e atividades das bibliotecas}

DSC

São muito bons, não sei se já dá pra sentir a diferença na execução dos trabalhos.
É muito importante e fundamental capacitar o funcionário; acho que agora é
preciso ver o que mudou na prestação de serviços, ver o que melhorou, acho
super importante avaliar o reflexo disso nas bibliotecas. Isso será medido um dia,
se há retorno de melhoria para o serviço?

\section{F - A aplicação dos conhecimentos na prática das bibliotecas não ocorre naturalmente}

\section{DSC}

Acho ótimo, saio bastante satisfeita e empolgada mas quando chego na Unidade nem sempre é fácil pra implantar ou aplicar no ambiente do trabalho, é muito difícil por em prática. Às vezes o entrave está aqui, não é tão fácil assim aplicar no seu local de trabalho o que aprendeu, precisa a direção da biblioteca querer também e às vezes demora um pouco pra isso ficar claro, então isso frustra demais pois você volta pra unidade e já logo quer usar o que aprendeu. Isso acontece com todos, a gente conversa com outras pessoas que também falam isso, os colegas também dizem que nem sempre recebem todo apoio pra depois usar o que aprenderam, tendo que mudar algumas coisas. 


\section{Proporcionam as mesmas oportunidades de participação para as} três categorias de profissionais das bibliotecas: bibliotecários, técnicos e básicos, é a ldéia central que representa 29,70\% das 47 respostas, confirmando mais uma vez a importância dos quesitos justiça e oportunidades, neste caso, com relação a treinamentos e capacitação, e relacionados pelos sujeitos de pesquisa como motivadores, grifo nosso, conforme trecho do DSC:

“... principalmente os técnicos e básicos que agora tem essa oportunidade, afinal é uma inovação a participação de todos que compõem as equipes, é muito democrático e inclusivo, é a nossa oportunidade prá se manter atualizado, para todos os funcionários igualmente. Conversei com outros técnicos de outras bibliotecas que acham muito importante que continue, com todos participando, pois significam oportunidades para os funcionários do sistema aprenderem coisas novas e é bem motivador, pois todos sabem que poderão freqüentar..."

A despeito da diversidade de abordagens e teorias de entendimento da motivação humana no trabalho, mas sendo o desenrolar do processo motivacional uma dinâmica de caráter interior, o aspecto mais importante no contexto das atividades desenvolvidas como parte de um trabalho, é entender o sentido que as pessoas atribuem àquilo que fazem e mobiliza-las em seus papeis na organização, imprimindo rumos, definindo ações e comportamentos e estabelecendo metas e resultados a serem cumpridos, como refere-se BERGAMINI (2003, p. 64)

“... trabalhar passa a representar uma necessidade de ordem afetiva continuamente alimentada pelo imperativo daqueles valores representados pelo objetivo almejado, e a partir dessa perspectiva reconhece-se o papel 
crucial que as necessidades interiores desempenham no processo motivacional."

Ou dito de outra forma:

“ O papel do gestor deverá ser sempre o de identificar os norteadores de comportamento de seus subordinados, assumindo a natureza intrínseca e individual da motivação de modo a gerir a direção de energia que naturalmente se encontra dentro de cada um num sentido compatível com os objetivos da organização e com o crescimento de cada integrante de seu grupo de trabalho." (CASADO, 2002, p. 257)

As ações de capacitação empreendidas pelo DT/SIBi são referidas na Idéia central Reflete a preocupação com a capacitação e atualização das equipes pelo $\mathrm{DT} / \mathrm{SIBi}$, e o reconhecimento dos treinamentos recebidos como instrumento de melhoria profissional são explicitados no trecho de DSC:

“... porque treinamento é sempre bom, e a capacitação ti dá recursos pra melhorar na profissão, reforçando o comprometimento."

A obtenção de capacitação é necessária na construção do que DUTRA (2002, p. 103) chama de projeto profissional, para o qual a carreira e sua evolução é um dos elementos, com acesso às experiências profissionais necessárias para competir pelas oportunidades e para atingir as metas.

Proporciona a integração das equipes das bibliotecas do Sistema e a troca de experiências, é a Idéia central em que aparece a noção de integração do Sistema, 
... possibilita a integração com outras pessoas, dos outros modelos de bibliotecas do SIBi que são mais ou menos parecidas, mas acaba conhecendo o ambiente de trabalho do outro e você também tem visão do trabalho que o outro faz, e fica sabendo dos problemas que ele também enfrenta... oferece os programas e treinamentos a todos os funcionários que são envolvidos e que falam de biblioteca mas o bom mesmo é a integração dos profissionais que vão fazer para que tenhamos uma visão sistêmica... a integração que isso proporciona já vale pois você conversa com outros colegas que fazem a mesma coisa

À Idéia central São proveitosos para enriquecer o currículo e concorrer ao Acesso na Carreira corresponde um DSC que reflete a prática:

Prá mim foi muito proveitoso, eu consegui usar isso daí nessa classificação que teve [Programa de acesso na carreira]; me ajudou muito e eu passei

No entanto, há referências às dificuldades de aplicação ou incorporação do que é aprendido, nas atividades das bibliotecas:

“... nem sempre é fácil pra implantar ou aplicar no ambiente do trabalho...”

e à importância de avaliar os resultados dessas capacitações nos serviços prestados,

“... acho que agora é preciso ver o que mudou na prestação de serviços, ver o que melhorou..."

As Idéias centrais relativas aos discursos citados: São bons, mas ainda não são conhecidos os resultados dessas participações e suas aplicações nas atividades das bibliotecas e $\mathrm{O}$ conhecimento adquirido é importante, mas há dificuldades para sua aplicação, nas bibliotecas, têm igual representação percentual, de 10,64 para cada uma e revelam que 
os indivíduos treinados apreenderam não somente o conteúdo desses treinamentos como a sua importância na prestação dos serviços.

Ao abordar os aspectos da qualidade na prestação de serviços e sua relação com a capacitação, LAS CASAS (1999, p. 125) afirma,

" A capacitação é uma das atividades essenciais para a prestação de serviços com qualidade. A razão disso é óbvia. A prestação de serviços é alicerçada no desempenho humano e prestar bons serviços depende da qualidade desse desempenho humano. Portanto, aperfeiçoar serviços é aperfeiçoar desempenho humano, o que é possível, principalmente através da capacitação."

CAVALCANTE (2006) ao discorrer sobre o treinamento em bibliotecas universitárias e suas relações com a qualidade dos serviços prestados, pondera que um programa de treinamento deve ser elaborado com a participação de gerentes e líderes das unidades de informação, tendo em vista o nível e a abrangência do conhecimento das equipes e das necessidades dos setores, numa visão ampla que permita alterações e ajustes contínuos, de acordo com os parâmetros institucionais. 


\section{$5^{\text {a }}$ Pergunta}

Você se considera um colaborador comprometido? Por que, ou ainda, que fatores você considera que contribuem para isso?

QUADRO 5 - SíNTESE DAS IDÉIAS CENTRAIS PARA A 5르 PERGUNTA

\begin{tabular}{|c|l|c|c|}
\hline & \multicolumn{1}{|c|}{ Idéias centrais } & $\mathrm{N}$ & $\%$ \\
\hline A & $\begin{array}{l}\text { Sim, porque sei desempenhar minha atividade, tenho } \\
\text { segurança e também sei da importância do meu papel na } \\
\text { instituição }\end{array}$ & 12 & 26,09 \\
\hline B & $\begin{array}{l}\text { Sim, por razões que são mais pessoais do que } \\
\text { relacionadas com o trabalho. }\end{array}$ & 3 & 6,52 \\
\hline C & Sim, gosto do que faço e do ambiente de trabalho & 25 & 54,35 \\
\hline D & $\begin{array}{l}\text { Sim, recebo reconhecimento e incentivo pelo trabalho que } \\
\text { executo }\end{array}$ & 2 & 4,35 \\
\hline E & $\begin{array}{l}\text { Sim, conheço a instituição, suas necessidades e seus } \\
\text { propósitos }\end{array}$ & 4 & 8,70 \\
\hline TOTAL DE RESPOSTAS DA PERGUNTA & $\mathbf{4 6}$ & $\mathbf{1 0 0}$ \\
\hline
\end{tabular}

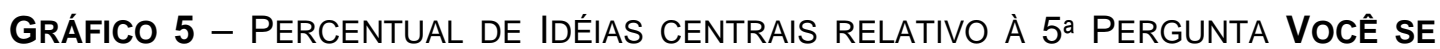
CONSIDERA UM COLABORADOR COMPROMETIDO? POR QUE, OU AINDA, QUE FATORES VOCÊ CONSIDERA QUE CONTRIBUEM PARA ISSO?

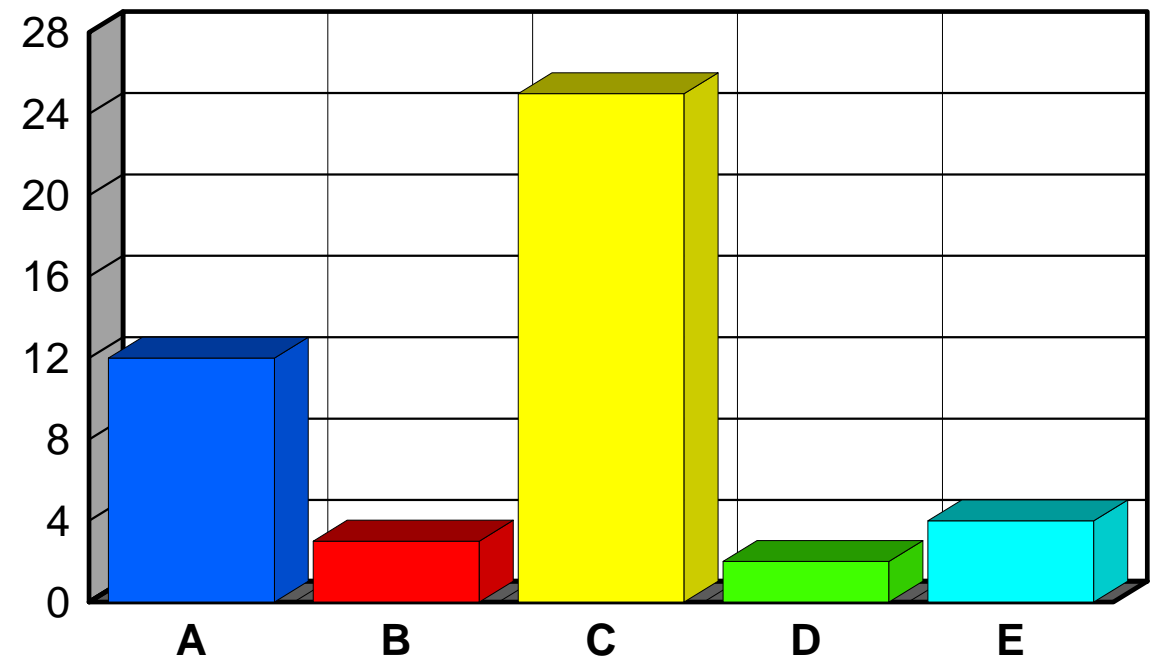




\section{Critérios utilizados para a inserção nas idéias centrais}

A - Sim, porque sei desempenhar minha atividade, tenho segurança e também sei o meu papel e sua importância

Possui conhecimento para o desempenho de suas atividades, com segurança e sabendo a importância do seu papel para a instituição.

B - Sim, por razões que são mais pessoais do que relacionadas com o trabalho

O comprometimento é referido como uma característica pessoal presente também em outros aspectos, que não o trabalho.

C - Sim, gosto do que faço e do ambiente de trabalho

Acima de tudo porque gosta do que faz e do ambiente em que trabalha.

D - Sim, recebo reconhecimento e incentivo pelo trabalho que executo

É referido o incentivo e o reconhecimento pelo trabalho desenvolvido.

E-Sim, conheço a instituição, suas necessidades e seus propósitos.

O comprometimento tem a ver com o conhecimento das necessidades da instituição e a disposição para trabalhar para essas necessidades.

\section{A - Sim, porque sei desempenhar minha atividade, tenho segurança e também sei o meu papel e sua importância}

\section{DSC}

Eu me considero um profissional comprometido e o que contribui prá isso é que eu sei o que faço, tenho experiência, tenho segurança daquilo que eu faço junto com outras partes daquilo que as outras pessoas fazem e que forma o todo que é a biblioteca, enfim, tenho comprometimento com a biblioteca onde estou, a faculdade e a Universidade, pois eu conheço meu local de trabalho, o meu serviço, domino as técnicas que preciso e sei o meu pedaço e a importância dele nesse contexto. Eu assumi comprometimento de nível profissional, conheço a biblioteca e as necessidades dela e posso responder e colaborar pois a pessoa comprometida é assim, ela sabe o que faz pois dominar a sua atividade é uma necessidade. 


\title{
B - Sim, por razões que são mais pessoais do que relacionadas com o trabalho.
}

\section{DSC}

Eu me considero bastante comprometida, mais por razões individuais e pessoais do que no sentido da organização, eu digo no contexto do nosso empregador; sou assim mesmo na minha vida, encaro dessa forma, não faço por fazer. Eu sou mesmo comprometida, mesmo se não tivesse nada disso e antes mesmo de começar essas palestras por causa da qualidade, o SDG, que começou mesmo a envolver toda a equipe nas tarefas do $5 \mathrm{~S}$ por exemplo, eu sou por mim mesma.

\section{C - Sim, gosto do que faço e do ambiente de trabalho}

\section{DSC}

\begin{abstract}
Eu me considero um profissional comprometido, nunca falto, tenho aqui um bocado de amizade e eu gosto muito do que faço e como eu já disse fazer o que gosta representa $80 \%$ do comprometimento; quero trabalhar e não quero dar meu lugar prá outra pessoa, pois eu gosto do ambiente e tenho empatia com as atividades desenvolvidas. Fui fazer biblioteconomia porque queria, e gosto ainda e no decorrer de todos esses anos continuo gostando muito, acho que se não gostasse não seria tão assim. Acontecem coisas como por exemplo, uma vez atendemos uma pessoa que estava de passagem e nos pediu 8 artigos pra serem mandados, porque sabia que era mais barato que na BIREME. Mandamos os artigos e depois veio um e-mail agradecendo e dizendo que essa pessoa tinha um caso de doença do coração de uma criança e que só nós tínhamos os artigos que ajudaram ela a resolver o caso. Ficamos muito emocionadas e contentes porque mesmo não tendo um CRM pudemos ajudar na solução da doença. O meu pessoal também tem esse comprometimento e acho que o que ajuda é o ambiente de trabalho, aqui na Unidade existe um clima de colaboração, todos convivem e se relacionam e é um clima e um ambiente muito bons. Sempre fui assim quando gosto do que faço e faço diversas coisas que me dão satisfação, eu sou feliz; o que me levou a isso é ter condições favoráveis pro meu trabalho, um bom ambiente, bons relacionamentos, eu trabalho visando o ambiente da biblioteca como um todo e construindo relacionamentos, que é o que nós temos, porque a partir do momento em que o profissional se sente bem no seu ambiente de trabalho, então está comprometido não só com a biblioteca mas com o Sistema de biblioteca; não sei se é pelo tempo de tenho aqui mas eu sempre visto a camisa daqui e procuro sempre fazer melhor, mas se a pessoa não gosta do que faz...
\end{abstract}

\section{D - Sim, recebo reconhecimento e incentivo pelo trabalho que executo}

DSC

Sim, acima de tudo me comprometo porque eu sempre recebi incentivo prá isso, o reconhecimento e um bom retorno do meu trabalho. 


\section{E - Sim, conheço a instituição, suas necessidades e seus propósitos.}

\section{DSC}

Sim, me comprometo com meu trabalho e sei o que tenho que fazer pra dar resultados, com o bom andamento da biblioteca e procuro sempre garantir a qualidade dos serviços prestados. Eu sei o que a biblioteca espera de mim então é muito mais fácil, eu tenho a responsabilidade de me comprometer com aquilo que é o meu trabalho e me comprometo; de modo geral os funcionários das bibliotecas na USP, são comprometidos com o que fazem, alguns mais e outros menos, mas são comprometidos e geralmente gostam do trabalho que fazem.

Na Idéia central Sim, gosto do que faço e do ambiente de trabalho, estão as opiniões de 25 dos 46 sujeitos da pesquisa, representando $54,35 \%$ do total, evidenciando os achados das perguntas anteriores que apontam a importância dada ao gosto pelo trabalho e pelo ambiente, embora de forma menos enfática.

BERGAMINI (2003, p. 67) refere-se ao “... indivíduo engajado em uma atividade que para ele faz sentido..."; para esse indivíduo e para uma dimensão maior da sua qualidade de vida, as organizações adotam, o que ALBUQUERQUE e FRANÇA (1998, p. 41) abordam como, “... um conjunto de ações que envolve diagnóstico e implantação de melhorias e inovações gerenciais, tecnológicas e estruturais dentro e fora do ambiente de trabalho, visando propiciar condições plenas de desenvolvimento humano para e durante a realização do trabalho." 
Em Sim, recebo reconhecimento e incentivo pelo trabalho que executo, o percentual é apenas $4,35 \%$ do total de respostas enquanto que é de $25,00 \%$, o maior para pergunta, quando os fatores reconhecimento e incentivo são apontados como estímulo ao comprometimento organizacional, na $3^{\text {a }}$ pergunta: ... que fatores você acha que auxiliariam no comprometimento dos profissionais das bibliotecas?

Para a Idéia central Sim, porque sei desempenhar minha atividade, tenho segurança e também sei da importância do meu papel na instituição, é possível recorrer à simplificação do conceito de socialização, proposto em SHINYASHIKI (2002, p. 168) como a uniformidade entre os membros de uma sociedade e certo grau de controle social sobre os comportamentos dos indivíduos e assim abordar os papéis, como parte da compreensão dessa socialização, quando ocorre no contexto da organização: a definição do papel dará ao funcionário a compreensão das suas tarefas, das suas prioridades, dos espaços a serem ocupados. O autor refere-se a Rizzo (1970) e a teoria de papéis para explicar que: quando o comportamento esperado é inconsistente, ou há conflito de papeis, o indivíduo torna-se insatisfeito e menos eficaz.

Ao observar o trecho de DSC,

“... eu conheço meu local de trabalho, o meu serviço, domino as técnicas que preciso e sei o meu pedaço e a importância dele nesse contexto."

à luz do que explica SHINYASHIKI, é possível entender o discurso explicitado pelo sujeito de pesquisa que se diz comprometido. 
Mais uma vez, a exemplo de perguntas anteriores, são referidos os componentes de prestação de serviços da instituição, representando algo além da simples lealdade passiva a uma organização, pois o indivíduo deseja dar algo de si para contribuir, segundo o que pensam MOWDAY, STEERS e PORTER (1987) 


\section{$6^{\text {a }}$ Pergunta}

\section{O que é para você um colaborador ideal em termos de comprometimento?}

QUADRO 6 - SíNTESE DAS IDÉIAS CENTRAIS DA 6a PERGUNTA

\begin{tabular}{|c|l|c|c|}
\hline & \multicolumn{1}{|c|}{ Idéias centrais } & $\mathrm{N}$ & $\%$ \\
\hline A & $\begin{array}{l}\text { O funcionário que conhece e desempenha a contento, } \\
\text { suas atividades. }\end{array}$ & 8 & 17,78 \\
\hline B & Está disposto à aprendizagem contínua. & 14 & 31,11 \\
\hline C & $\begin{array}{l}\text { Gosta do que faz e colabora para bons relacionamentos e } \\
\text { para um bom ambiente de trabalho. }\end{array}$ & 7 & 15,56 \\
\hline D & Usa a criatividade no desempenho de suas atividades. & 2 & 4,44 \\
\hline E & $\begin{array}{l}\text { Desempenha suas atividades de acordo com a } \\
\text { compreensão que tem da instituição e de suas } \\
\text { necessidades. }\end{array}$ & 14 & 31,11 \\
\hline & TOTAL DE RESPOSTAS DA PERGUNTA & $\mathbf{4 5}$ & $\mathbf{1 0 0}$ \\
\hline
\end{tabular}

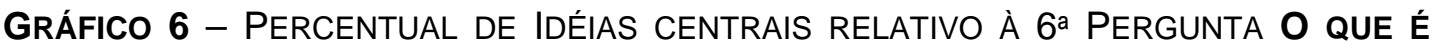
PARA VOCÊ UM COLABORADOR IDEAL EM TERMOS DE COMPROMETIMENTO?
}

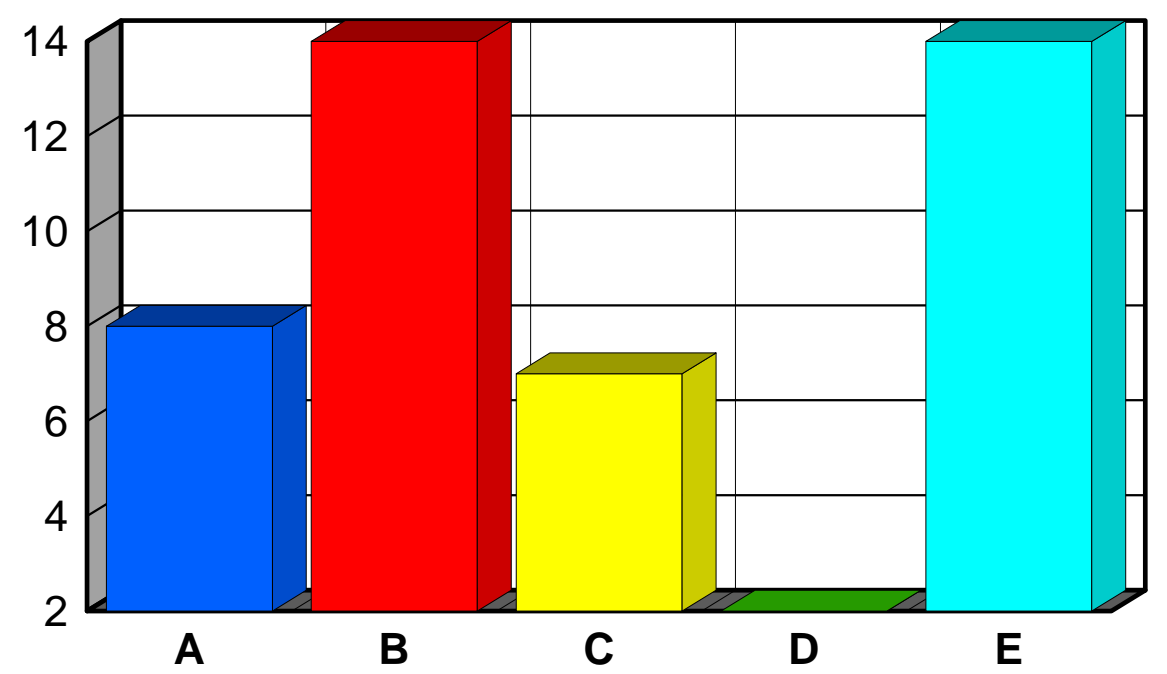


Critérios utilizados para a inserção nas Idéias centrais A - O funcionário que conhece e desempenha, a contento, suas atividades Conhece tecnicamente o seu trabalho, tem clareza do seu papel e do que deve entregar para a instituição.

\section{B - Está disposto à capacitação contínua}

Apresenta disposição para aprender não só para o seu crescimento profissional como também para a tender necessidades do serviço.

C - Gosta do que faz e colabora para bons relacionamentos e bom ambiente de trabalho

Acima de tudo gosta do seu trabalho e tem bons relacionamentos, por gostar também do ambiente.

D - Usa a criatividade no desempenho de suas atividades

A criatividade é referida como qualidade para o bom desempenho.

E - Desempenha suas atividades de acordo com a compreensão que tem da instituição e suas necessidades

Conhece, compreende e age de acordo com a missão, visão e valores da instituição e para o cumprimento de seus objetivos.

\section{A - O funcionário que conhece e desempenha, a contento, suas atividades.}

\section{DSC}

É aquele que sabe fazer a parte dele, sabendo as suas atividades é capaz de desempenhar bem, sabendo outras coisas também é colaborativo, e é comprometido. Isso é um profissional comprometido ideal com tantas características: tem clareza das suas atividades, tem uma capacidade de entrega de serviço alem do esperado, sabe que é capaz de fazer e sempre que é solicitado se oferece e faz mais, é um funcionário estudado, sabe o seu trabalho e tem competência prá fazer o que faz. Isso é a pessoa comprometida.

\section{B - Está disposto à capacitação contínua}

\section{DSC}

A pessoa comprometida tem iniciativa, disposição pra pedir prá aprender; então o funcionário ideal tem que ter disposição prá aprender, tem consciência de atualização e aquela coisa de crescimento profissional pelo estudo: querer 
aprender sempre e sempre capacitar. Então são muitas qualidades necessárias mas o ideal é ter a capacitação e a formação necessárias como requisitos básicos, mas também crescer e pra isso tem que querer fazer o seu trabalho cada vez melhor, usando as oportunidades, os cursos pra melhorar sempre, aprendendo e estudando, já está bom. Não existe uma coisa que diga que tal pessoa é comprometida, isso vai sendo construído; a gente não é o mesmo profissional que foi há dez anos atrás, e vai aprendendo sem parar, e vai se comprometendo, pois está sempre disposto a se capacitar. Bem, é um perfil de habilidades técnicas somadas à disposição para aprender mais e sempre, porque é super necessário.

\section{C - Gosta do que faz e colabora para bons relacionamentos e bom ambiente de trabalho}

\section{DSC}

Olha, o ideal mesmo é a pessoa gostar do que faz, antes de tudo faz porque gosta e com prazer e gostando é o ideal, pois respeita seus colegas e o ambiente, aceita as idéias dos outros mas também dá opinião e interage, participa pro ambiente ficar bom, é participativo colaborando com as pessoas e valorizando esse ambiente que é de grande ajuda para que as pessoas se comprometam. O funcionário ideal tem que ter isso, além de estar apto; já na entrevista tem que ver se ele gosta do que vai fazer, isso é importante, precisa gostar do trabalho e de colaborar com as pessoas, e se ele gosta então é ideal.

\section{D - Usa a criatividade no desempenho de suas atividades}

\section{DSC}

A pessoa comprometida não está ali prá brincar não, ela vem, procura acertar tem bons resultados, se tem dificuldades vai usar a criatividade pra resolver e procurar aprender por ela mesma ou por cursos que vai fazer. É quem vem já animado, criativo e tem todo o conhecimento necessário, tem a formação e quer contribuir para o todo. 


\section{E- Desempenha suas atividades de acordo com a compreensão que tem da instituição e suas necessidades}

\section{DSC}

Quem é mesmo comprometido usa a sua capacidade pra seguir os mesmos objetivos da instituição, age de acordo com esses objetivos, sabe qual é a missão e o negócio pro qual trabalha e trabalha pra que essa missão se realize, desenvolvendo suas atividades com base na missão e nos objetivos da organização, pois apreendeu seu serviço e faz de acordo com os valores da instituição onde atua. Além disso procura sempre agregar valor ao que faz, criando condições para o sucesso da organização, sua missão e suas metas e aceita quando pedem pra ele melhorar, para atualizar-se, para dar o melhor de si pois a instituição precisa dele. Executa seu trabalho pensando no todo, não só nas suas atividades, mas com visão do global dessa organização, pois entra sabendo quais são as regras e concorda, vai fazer e do jeito que precisa ser feito, porque está no comprometimento, assumindo integralmente e conhecendo o seu local de trabalho, sua história, absorvendo os ensinamentos do seu dia-adia do trabalho, aprendendo e revertendo isso em resultados para a instituição, enfim, colaborando com a sua parte. Ele não só desempenha sua atividades mas faz isso direito pra melhorar os processos da biblioteca e ela atingir seus objetivos, faz tudo o que pode pela biblioteca e vai saber o seu papel e vai se encaixar, pensando em colaborar pra que a instituição cumpra sua missão e seus objetivos.

\section{- Está disposto à aprendizagem contínua}

- Desempenha suas atividades de acordo com a compreensão que tem da instituição e de suas necessidades.

As duas Idéias centrais tem a mesma representação de $31,11 \%$ nas

45 respostas para a pergunta sobre o que é, na opinião dos respondentes, o colaborador ideal. Cada uma delas refere-se a um lado das relações do trabalho, de um lado é o compromisso com o aprendizado do próprio funcionário e do outro e a medida da compreensão do que é, para ele, a organização:

“... a gente não é o mesmo profissional que foi há dez anos atrás, e vai aprendendo sem parar, e vai se comprometendo, pois está sempre disposto a se capacitar e colaborar pois colaborar é fundamental para quem se 
compromete com a equipes de trabalho e ter espírito de equipe pois sem isso não vai chegar a nada. Bem, é um perfil de habilidades técnicas somadas à disposição para aprender mais e sempre..."

“... procura sempre agregar valor ao que faz, criando condições para o sucesso da organização, sua missão e suas metas e aceita quando pedem pra ele melhorar, para atualizar-se, para dar o melhor de si pois a instituição precisa dele. Executa seu trabalho pensando no todo, não só nas suas atividades, mas com visão do global dessa organização..."

CAVALCANTE (2006) refere-se às pessoas nas bibliotecas, como organizações, e seus objetivos: as bibliotecas universitárias, enquanto organizações ligadas à instituição maior que é a universidade, possuem características definidas a partir da missão da própria universidade, que baseia-se em proporcionar e garantir educação de qualidade através do ensino, pesquisa e extensão, servindo assim à sociedade.

A Idéia central Usa a criatividade no desempenho de suas atividades, tem no DSC o trecho:

... se tem dificuldades vai usar a criatividade pra resolver e procurar aprender por ela mesma...

O fator criatividade é referido como uma característica de quem é idealmente comprometido com a organização e portanto pressupõe que haja disposição para o esforço da criatividade, na busca de soluções para solução de problemas ou inovação, além de estar relacionada, de certa forma, com a Idéia central da $3^{\text {a }}$ pergunta Autonomia,

Certa autonomia pra resolver os assuntos do cotidiano é importante... 


\section{Considerações Finais}


No início da elaboração deste trabalho, na fase de pesquisa bibliográfica para revisão da literatura, foi possível constatar que os autores têm diferentes abordagens e enfoques no estudo do Comprometimento Organizacional, sendo ainda um conceito em construção.

Nas respostas para a 1ㄹ Pergunta,

\section{A seu ver o que é o Comprometimento Organizacional?,}

chamam a atenção os maiores percentuais para a explicação do que é comprometimento organizacional, que se referem à instituição e sua missão, visão, valores e objetivos, enquanto que fatores como o gosto pelo trabalho e pelo ambiente, têm representação consideravelmente inferior.

As respostas que referem a instituição e os fatores relativos a ela somam $60,29 \%$ das respostas para a pergunta, evidenciando a concordância com os autores que serviram de base para o estudo retrospectivo de ALBUQUERQUE (2002, p. 226), a respeito do tema Comprometimento: Mowday, Steers e Porter.

Os autores tratam do comprometimento como “... a relação forte entre o indivíduo identificado e envolvido numa organização...".

Os aspectos de trabalhar em benefício da organização, estando de acordo com os objetivos e valores dessa organização e com desejo de se manter como membro, que são abordados por Albuquerque, estão presentes nos trechos de DSCs deste trabalho:

Comprometimento organizacional é quando o funcionário ou as equipes de funcionários inseridos na biblioteca, na Unidade e mesmo na Universidade têm interesse, conhecem, compreendem o negócio, e assumem como seus, os valores, a missão da organização, seus objetivos, suas diretrizes e suas políticas, com as normas, as leis e as regras definidas para a organização como um todo. Em concordância com isso, e afinados com os objetivos da instituição, os funcionários têm 
comportamentos, atitudes e realizam suas ações, dispostos a trabalhar sabendo o que a instituição espera deles e com o compromisso de obter os resultados que a instituição estipulou para alcançar suas metas e seus objetivos e até superá-los.

Há evidências de que os sujeitos de pesquisa direcionam "seus olhares" mais para a instituição do que para os aspectos pessoais de sua inserção profissional, pelo menos no caso dessa pergunta.

Os conceitos de missão, visão e valores que têm sido difundidos no Sistema (SIBi/USP) e que estão presentes nos conteúdos dos treinamentos e capacitações oferecidos às equipes, provavelmente têm um papel importante nas respostas obtidas, significando que estes conceitos estão internalizados pelos indivíduos dessas equipes, a ponto de serem explicitados nas respostas dadas por eles.

Respeito e boas relações com os chefes não são referidos como fatores que favorecem o comprometimento, mas a falta deles é apontada pelos respondentes, como impeditivos ao comprometimento organizacional.

Como fica revelado, nem sempre fatores cuja existência desestimulam o comprometimento, uma vez solucionados, se reverterão em estímulo ao Comprometimento organizacional. Isso evidencia a necessidade de preparar as equipes do sistema e principalmente seus líderes e responsáveis para garantir que o respeito e o bom relacionamento estejam presentes no ambiente de trabalho.

Nas questões relativas ao programa de capacitação, realizado pelo DT/SIBi para as equipes do Sistema, é inegável a satisfação contida nas 
respostas dos entrevistados, com o fato de ser facultado aos três níveis profissionais das bibliotecas, bibliotecários, técnicos e básicos.

Ao mesmo tempo outras duas Idéias centrais:

- São bons, mas ainda não são conhecidos os resultados dessas participações e suas aplicações nas atividades das bibliotecas

- O conhecimento adquirido é importante, mas há dificuldades para sua aplicação, nas bibliotecas,

revelam que os indivíduos treinados apreenderam não somente o conteúdo desses treinamentos, como têm clara a sua importância na prestação dos serviços, que poderá ser objeto de estudo pela avaliação dos serviços prestados após a aquisição dos novos conhecimentos.

No entanto é preciso ponderar sobre o conteúdo ministrado nesses treinamentos, que deverão atender às necessidades específicas das funções dos indivíduos e às necessidades da prestação do serviço, e que devem coincidir com as demandas identificadas nas manifestações dos usuários desses serviços.

Além disso é recomendável a avaliação específica do impacto desse investimento em capacitação pelo DT/SIBi, além do que pode ser observado de forma indireta pela análise quantitativa das informações sistematizadas na publicação Dados Estatísticos do Sistema Integrado de Bibliotecas, editado anualmente. 
Atenção também deve ser dada aos fatores reconhecimento e incentivo no trabalho, que assumem uma maior representação quando são referidos pelos sujeitos de pesquisa como fatores que auxiliariam no Comprometimento organizacional, representando $25,00 \%$ do total de respostas, enquanto que apenas 4,35\% referem esses fatores como motivo para afirmarem que os sujeitos estão comprometidos.

É possível então inferir que atos ou palavras de reconhecimento e incentivo pelo trabalho a ser executado, por si só não levam ao Comprometimento Organizacional, mas são práticas que devem estar presentes na gestão das pessoas, nas bibliotecas do Sistema e devem merecer atenção na definição de diretrizes para as ações de capacitação.

Para a 6ํㅗ Pergunta:

O que é para você um colaborador ideal em termos de comprometimento?

os entrevistados, além das referências ao bom desempenho, à aprendizagem contínua, aos bons relacionamentos e à compreensão das necessidades da instituição, referem a criatividade como um elemento que não aparece nas perguntas anteriores.

Podemos observar que as respostas obtidas nesta pergunta, demonstram mais, uma vez a presença do fator que aponta a necessidade de compreensão da instituição e suas necessidades.

Essas duas Idéias Centrais: 
- Desempenha suas atividades de acordo com a compreensão que tem da instituição e de suas necessidades e

- Disposição para a aprendizagem contínua,

somam $62,22 \%$ do total de respostas.

Este percentual reafirma a prevalência das Idéias Centrais da $1^{\underline{a}}$ Pergunta sobre o que é o Comprometimento: Ter conhecimento e concordância com os objetivos da instituição e Reconhecer seu dever e sua responsabilidade com a qualidade das atividades desenvolvidas na instituição, que somadas representam $60,29 \%$, como já foi referido nas considerações sobre a $1^{\text {a }}$ Pergunta.

Considerando ainda, a criatividade, a exemplo de outros atributos relacionados com o Comprometimento organizacional, uma abordagem socio-interativa, é importante o esforço para a manutenção de um ambiente favorável e de aperfeiçoamento das habilidades dos gerentes, líderes e responsáveis pela gestão das pessoas, nas bibliotecas do Sistema.

Situações e fatores que levam ao Comprometimento organizacional têm em seus antecedentes, além daqueles inerentes à própria organização e sua gestão, as experiências e histórias de vida das pessoas, que ao desenvolverem suas capacidades individuais, colaboram e permitem que a organização cumpra seus objetivos.

Nesse sentido, é importante a preocupação dos gestores e líderes com a qualidade de vida das pessoas no trabalho e a busca do 
aprimoramento profissional dos indivíduos das equipes, o que é reforçado pela opinião de PAULINO (2000, p. 205),

“... é preciso reconhecer que as pessoas podem fazer suas próprias escolhas; que podem agir, relacionarem-se e decidirem de acordo com seus sentimentos, emoções e/ou necessidades; que as pessoas são produtos de seu ambiente de trabalho à medida que encontrem situações que gerem seu bem-estar pessoal, ou seja, podem ser mais criativas, mais comprometidas e pró-ativas quando estão em um ambiente mais harmonioso em relação às condições de trabalho, equipamentos, tratamento e reconhecimento." 


\section{Referências}


Albuquerque LG, França ACL. Estratégias de RH e gestão da qualidade de vida no trabalho: o stress e a expansão do conceito de qualidade total. Rev Admin, São Paulo. 1998;33(2):40-51.

Albuquerque LG. Estratégias de recursos humanos e competitividade. In: Vieira MMF, Oliveira LMB, organizadores. Administração contemporânea: perspectivas estratégicas. São Paulo: Atlas; 1999.

Albuquerque LG. A gestão estratégica de pessoas. In: Fleury MTL, organizador. As pessoas na organização. São Paulo: Gente; 2002. p. 35-50.

Almeida Junior OF. Profissional da informação: entre o espírito e a produção. In: Valentim ML O profissional da Informação: formação, perfil e atuação profissional. São Paulo: Polis; 2000. p.31-51.

Arruda MCC, Marteleto RM, Souza DB. Educação, trabalho e o delineamento de novos perfis profissionais: o bibliotecário em questão. Ci Inf. 2000;29(3):14-24.

Barbalho CRS. Gestão pela qualidade: referencial teórico. Transinformação, Campinas. 1996;8(3):97-120.

Barbalho CRS, Beraquet VSM. Planejamento estratégico para unidades de informação. São Paulo: Polis/APB; 1995.

Bastos ABV. Comprometimento no trabalho: a estrutura dos vínculos do trabalhador com a organização, a carreira e o sindicato [tese de doutorado]. Brasília: Instituto de Psicologia da Universidade de Brasília; 1994. 
Bastos ABV. Padrões de comprometimento com a profissão e a organização: o impacto de fatores pessoais e da natureza do trabalho. Rev Administração. (São Paulo) 2000;35(4):48-60.

Becker TE. Focus and bases of commitment: are they distinctions worth making? Acad Manage J. 1992;35:232-44.

Belluzzo RCB. Da capacitação de recursos humanos `gestão da qualidade em bibliotecas universitárias: paradigmas teórico-práticos para ambiente deServiço de Referência e Informação [tese de doutorado]. São Paulo: Escola de Comunicações e Artes da Universidade de São Paulo; 1995.

Belluzzo RCB, Macedo ND. A gestão da qualidade em serviços de informação: contribuição para uma base teórica. Ci Inf. 1993;22(2):124-32.

Belluzzo RCB, Carvalho T, Ferrari AC, Souza MFA, Flexa RMA. Capacitação de equipes bibliotecárias no Sistema Integrado de Bibliotecas da Universidade de São Paulo em face às novas dinâmicas de gestão da qualidade.In: Anais do IX Seminário Nacional de Bibliotecas Universitárias. Curitiba: UFPR; 1996.

Bergamini CW, Beraldo DGR. Avaliação de desempenho humano na empresa. São Paulo: Atlas; 1992.

Bergamini CW. Motivação: uma viagem ao centro do conceito. RAE executivo. 2002/2003;1(2):63-7.

Bonato, VL. Programas de qualidade em hospitais do Município de São Paulo [tese de doutorado]. São Paulo: Faculdade de Saúde Pública da USP; 2003. 
Borges-Andrade JE, Afanasieff RS, Silva MS. Mensuração de comprometimento organizacional em instituições públicas. In: Programa da XIX Reunião Anual de Psicologia. Ribeirão Preto: Sociedade de Psicologia de Ribeirão Preto; 1989.

Brasil. Resolução CNE/CES 19, de 13 de março de 2002. Diário Oficial da União. Brasília, 9 abr 2002; Seção 1:34.

BOWERS AM. Organizational reestructuring in academic libraries: a case study. J Lib Adm. 1996;22(2/3):133-44.

Bueno M. Programas de qualidade no setor avícola brasileiro: o caso da Granja Planalto [dissertação de mestrado]. Florianópolis: Faculdade de Engenharia de Produção da UFSC; 2002.

Carvalho AO, Eduardo MBP. Sistemas de informação em saúde para municípios. São Paulo: Faculdade de Saúde Pública USP; 1998. (Série Saúde \& Cidadania, 6)

Casado T. A motivação e o trabalho. In: Fleury MTL, organizador. As pessoas na organização. São Paulo: Gente; 2002. p.247-58.

Casado T, Matoso SS. Programa de melhoria de desempenho da RME: módulo II. São Paulo: FIA/USP; 1996.

Castro CA. Formação do profissional da informação: abordagem críticoreflexiva. In: Castro CA. Ciência da informação e biblioteconomia: múltiplos discursos. São Luís: EDUFMA; 2002. Cap.10, p.186-99. 
Cavalcante LE. Educação e aprendizagem contínua em unidades de informação. [acesso em 06 maio 2006]. Disponível em: http://www.biblioteca.ufc.br/arteucaçao.html

Chang Junior J. Gestão de pessoas pelo desenvolvimento do comprometimento organizacional: uma abordagem holística e simultânea dos determinantes envolvidos no processo [tese de doutorado]. São Paulo: Faculdade de Economia e Administração da USP; 2001.

Classificação Brasileira de Ocupações. [acesso em 17 maio 2007]. Disponível em: http://www.mtecbo.gov.br/busca.asp

Conselho Regional de Biblioteconomia 8를 Região. Bibliotecário e técnico em biblioteconomia: legislação. São Paulo; 1995.

Costa WS. Resgate da humanização no ambiente de trabalho. Cad Pesq Admin, São Paulo. 2002;9(2):13-23.

Deming WE Qualidade: a revolução da administração. Rio de Janeiro: Marques Saraiva; 1990.

Dessler G. Conquistando comprometimento: como construir e manter uma força de trabalho competitiva. São Paulo: Makron Books; 1996.

Dertouzos ML, Lester RK. Made in America: regaining the productive edge. Cambridge: MIT Press; 1990.

Dias MMK. O gerenciamento de unidades de informação tecnológica sob enfoque da qualidade: do estudo das percepções e reações do cliente ao desenho de novas condutas [tese de doutorado]. São Paulo: Escola de Comunicações e Artes da USP; 2001. 
Dias MMK, Belluzzo RCB. Gestão da informação em ciência e tecnologia sob a ótica do cliente. Bauru:EDUSC;2003.

Diniz de Sá MA, Lemoine C. O estilo de liderança como fator de comprometimento na empresa. [acesso em 09 ago 2006]. Disponível em: http://www.ppq.com.br/logfotos/enanpad\%2098.doc

Drucker PF. O gerente eficaz. Rio de Janeiro: Zahar; 1990.

Dutra J. Gestão de pessoas: modelo, processos, tendências e perspectivas. São Paulo: Atlas; 2002.

Faria S, Oliveira VF, Forner L, D'Astuto F. Competências do profissional da informação: uma reflexão a partir da Classificação Brasileira de Ocupações. Ci Inf. 2005;34(2):26-33.

Feingenbaum AV. Total quality control: engineering and management. New Yok: Mc Graw-Hill; 1986.

Fischer AL. Um resgate conceitual e histórico dos modelos de gestão de pessoas. In: Fleury MTL, organizador. As pessoas na organização. São Paulo: Gente; 2002. p. 11-34.

Fleury MTL. Cultura da qualidade e mudança organizacional. RAEeletrônica. 1993;33(2):26-34.

Fleury A, Fleury MTL. Estratégias empresariais e formação de competências: um quebra-cabeça caleidoscópio da industria brasileira. São Paulo: Atlas; 2004.

Foucault M. Microfísica do poder. Trad. de Roberto Marinho. Rio de Janeiro: Graal; 1979. 
Galvão MCB, Borges PCR. Ciência da informação: ciência recursiva no contexto da sociedade da informação. Ci Inf. 2000;29(3):40-9.

Hypólito A, Linguanotto ARJ, De Grandi MEG, Rosetto M, Sampaio MIC, Do Coutto MLM, Teixeira QJS. Desafios/tendências e novas posturas dos profissionais da informação frente à ARH. [acesso em 18 set 2005]. Disponível em: http://www.sibi.usp.br/aleph/ARH.htm

Hernon P, Nitecki DA, Altman E. Service quality and customer satisfaction: an assesment and future directions. J Acad Librarianship. 2005;25(1):1726.

Jodelet $\mathrm{D}$, organizador. As representações sociais. Trad. de Lilian Ulup. Rio de Janeiro: Editora da UERJ; 2001.

Junqueira C, Barreto S. Pesquisas de clima organizacional, satisfação dos colaboradores, comprometimento [acesso em 14 set 2006]. Disponível em : http://www.institutomvc.com.br/insight72.htm

Kotler P, Fox KFA. Marketing estratégico para instituições educacionais. São Paulo: Atlas; 1994.

Kotler P. Administração de marketing: análise, planejamento, implementaçào e controle. São Paulo: Atlas; 1998.

Lapierre L. Imaginário e liderança: na sociedade, no governo, nas empresas e na mídia. São Paulo: Atlas; 1995.

Las Casas AL. Qualidade total em serviços: conceitos e exercícios. São Paulo: Atlas; 1999.

Le Coadic Y. A ciência da informação. Brasília: Briquet de Lemos; 1996. 
Lefèvre F, Lefévre AMC. $O$ discurso do sujeito coletivo: um novo enfoque em pesquisa qualitativa (desdobramentos). Caxias do Sul: EDUCS; 2003.

Lefèvre F, Lefèvre AMC, Teixeira JJV. O discurso do sujeito coletivo: uma nova abordagem metodológica em pesquisa qualitativa. Caxias do Sul: EDUCS; 2000.

Lefèvre $F$, Lefèvre AMC. Recuperando a fala do social. São Paulo: Faculdade de Saúde Pública da USP; 1998. (Série Monográfica n.9)

Likert R. Novos padrões de administração. Trad. de Albertino Pinheiro Junior, Ernesto D’Orsi. São Paulo: Pioneira; 1971.

Loureiro MF, Jannuzzi PM. Profissionais da informação: um conceito em construção. Transinformação, Campinas. 2005;17(2):123-51.

Machado LRS. Educação e o desafio das novas tecnologias. In: Ferreti CJ. Novas tecnologias, trabalho e educação: um debate multidisciplinar. Petrópolis: Vozes;1996. p. 169-168.

McGarry K. O contexto dinâmico da informação: uma análise introdutória. Brasília, DF: Briquet de Lemos; 1999.

Marchiori PZ. O campo de atividades, a ciência e o espaço da gestão da informação In: Castro CA. Ciência da informação e biblioteconomia: múltiplos discursos. São Luís: EDUFMA; 2002. Cap.3, p.52-71.

Maximiano ACA. Introdução à administração. São Paulo: Atlas; 1990.

Medeiros CAF, Albuquerque LG, Siqueira M, Marques GM. Comprometimento organizacional: o estado da arte da pesquisa no Brasil. 
In: Anais do 26ํㅡㄹ Encontro da ANPAD-Associação Nacional dos Programas de Pós-Graduação em Administração. Salvador; 2002.

Medeiros CAF, Albuquerque LG, Siqueira M, Marques GM. Uma proposta de múltiplos componentes para o comprometimento organizacional [acesso em 9 mar 2006]. Disponível em: http://www.fgvsp/iberoamericana/Papers/0296

Meyer JP, Allen NJ. Commitment in the workplace: theory, research and application. Londres: Sage; 1997.

Minayo MCS. O desafio do conhecimento: pesquisa qualitativa em saúde. São Paulo: Hucitec-Abrasco; 2000.

Mintzberg H, Ahlstrand B, Lampel J. Safári da estratégia: um roteiro pela selva do planejamento estratégico. Porto Alegre: Bookman; 2000.

Miranda A. Ciência da informação: teoria e metodologia de uma área em expansão. Brasília: Thesaurus; 2003.

Mowday RT, Steers RM, Porter LW. The measurement of organizational commitment. J Vocational Behav. 1996;14:219-227.

Nascimento RB, Trompieri Filho N, Barros FGF. Avaliação da qualidade nos serviços prestados nas unidades de informação universitárias. Transinformação, Campinas. 2005;17(3):235-51.

Nogueira da Cruz H, Miranda O. Programa permanente de qualidade e produtividade da Universidade de São Paulo: uma década do Programa de Qualidade e Produtividade na USP: 1996-2005. São Paulo: Comissão de Gestão da Qualidade e Produtividade da USP; 2005. 
Oliveira M, Araújo EA. Os paradigmas da biblioteconomia e da ciência da informação e os novos contextos de informação. In: Castro CA. Ciência da informação e biblioteconomia: múltiplos discursos. São Luís: EDUFMA; 2002. Cap 2, p.36-49.

Pasquarelli MLR, Krzyzanovski RF. Estudo de estrutura organizacional para as bibliotecas da USP. São Paulo: SIBi/USP; 1998.

Paulino AD. Por onde começa a qualidade? In: Anais do I EGEPE, Curitiba; 2000. p.199-209.

Pinheiro EG, Costa MFO. Qualidade total em bibliotecas universitárias. A filosofia de Deming e a biblioteca universitária: uma nova relação em busca da gestão da qualidade [acesso em 06 set 2005]. Disponível em: http://www.biblioteca.ufc.br/artqualidade.html

Pinto VB. Informação: a chave para a qualidade total. Ci Inf. 1993;22(2):133-7.

Ramos PB. A gestão na organização de unidades de informação. Ci Inf. 1995;25(1):34-46.

Rave BNC, Uribe GC, Pérez PR. Después de la reingenhería nuevos modelos de servicios de información. Rev Interam Bibliot Medellin. $2001 ; 24(2): 7-51$.

Sá MAD, Lemoine C. O estilo de liderança como fator de comprometimento na empresa. In: Anais do 22ํㅡㄹ Encontro da ANPAD. Foz do Iguaçu; 1998. [CD-ROM]

Santos JLF, Westphal MF. Práticas emergentes de um novo paradigma de saúde: o papel da universidade. Estud Av. 1999;13(35):71-86. 
Santos LC, Fachin GRB, Varvakis G. Gerenciando processos de serviços em bibliotecas. Ci Inf. 2003;32(2):85-94.

Shinyashiki G. O processo de socialização organização. In: Fleury MTL. As pessoas na organização. São Paulo: Gente; 2002. p.165-84.

Smit JW, Barreto A. Ciência da informação: base conceitual para a formação do profissional. In: Valentim ML, organizador. Formação do profissional da informação. São Paulo: Polis; 2002. p.9-23.

Tarapanoff K, Suaiden E, Oliveira CL. Funções sociais e oportunidades para profissionais da informação. DataGramaZero, Rev Ci Inf. 2002; 3(5). [acesso em 1 ago 2006]. Disponível em: http://www.dgz.org.br/out02/F_I_art.htm.

Thévenet M. Impliquer les personnes dans l'entreprise. Paris: Liaisons;1986.

Travassos C, Santos SM, Szwarcwald CL, Barcellos C, Romero D, Bastos FI, Viacava F, Azevedo LO. Variáveis sociais nos bancos de dados de interesse para a área de saúde. In: I Seminário Nacional de Informação e Saúde. O setor no contexto da Sociedade de Informação. Rio de Janeiro, 2000. Anais. Rio de Janeiro: FIOCRUZ; 2000. p.35-41.

Universidade de São Paulo. Sistema Integrado de Bibliotecas. Departamento Técnico. Boletim Anual do Departamento Técnico do Sistema Integrado de Bibliotecas da Universidade de São Paulo - 2005. São Paulo: SIBi/USP; 2006.

Valentim ML. Formação do profissional da informação. São Paulo: Polis; 2002. Formação: competências e habilidades do profissional da informação; Cap 6, p.117-48. 
Vanti N. Ambiente de qualidade em uma biblioteca universitária: aplicação do 5 S e de um estilo participativo de administração. Ci Inf. 1999;28(3):3339.

Vivan AM, Fries D, Zanotelli CT. Implementação de um processo de qualidade a partir da metodologia do Programa 5"S". Cad Pesq Admin, São Paulo.1998;1.

Wiener Y. Commitment in organizations: a normative view. Acad Manag Review. 1982; 7(3):418-28. 
Anexos 


\section{ANEXO I}

\section{TERmo de Consentimento LiVRE E EsCLARECIDO}

Colegas bibliotecários e funcionários de bibliotecas,

Você está sendo convidado (a) a participar de pesquisa acadêmica para obtenção do grau de Doutorado, com o tema: "O COMPROMETIMENTO DE PESSOAS DE UM SISTEMA DE BIBLIOTECAS UNIVERSITARIAS.

O objetivo principal é identificar nos profissionais de bibliotecas, especificamente nos profissionais da área de saúde, suas opiniões sobre comprometimento organizacional, os programas de capacitação para a qualidade e portanto a busca do comprometimento das pessoas na organização.

A partir do seu consentimento, sua participação será o depoimento oral gravado em fita magnética e depois transcrito literalmente para a análise. $O$ material obtido ficará sob minha guarda, uma vez que eu procederei a análise, que será feita através de metodologia de pesquisa qualitativa: Discurso do Sujeito Coletivo.

Asseguro que, em momento algum seu nome será revelado ou relacionado com trechos dos depoimentos ou resultados do trabalho final, bem como é do seu direito, retirar-se da pesquisa se assim lhe convier, sem qualquer tipo de prejuízo.

Os resultados da pesquisa, sempre sem a revelação dos nomes dos entrevistados, poderão ser apresentados em evento científico da área ou ainda encaminhados para publicação sob a forma de artigos.

Comprometo-me ao retorno, para seu conhecimento, do trabalho concluído.

Desde já agradeço sua participação,

Maria Fazanelli Crestana

Aluna de Pós-Graduação. Nível de Doutorado da FSP/USP

RG 6526373

R. Volta Redonda 794, ap 123

Campo Belo - São Paulo - SP

Tel.: 55314207

Prof $^{\underline{a}}$ Dr ${ }^{-a}$ Vitoria Kedy Cornetta

Orientadora - FSP/USP 


\section{ANEXO II}

\section{ROTEIRO PARA ENTREVISTAS}

Nome da Biblioteca:

Idade Sexo

Bibliotecário

Nível Técnico

Nível Básico

Tempo de serviço na função

1. A seu ver, o que é comprometimento organizacional?

2. Vamos falar um pouco sobre comprometimento. Que situações ou fatores você acha que impedem um indivíduo de se comprometer com o trabalho, no ambiente das bibliotecas?

3. Ao contrário, na sua opinião, que fatores você acha que auxiliariam no comprometimento dos profissionais nas bibliotecas?

4. Nós os profissionais das bibliotecas da USP, nas três categorias, temos passado por programas de capacitação não é mesmo? Fale um pouco sobre o que isso significa prá você.

5. Você se considera um colaborador comprometido? Por que, ou ainda, que fatores você considera que contribuem para isso?

6. O que é para você um colaborador ideal em termos de comprometimento? 
ANEXo III

Resumos das Idéias Centrais - Quadro 


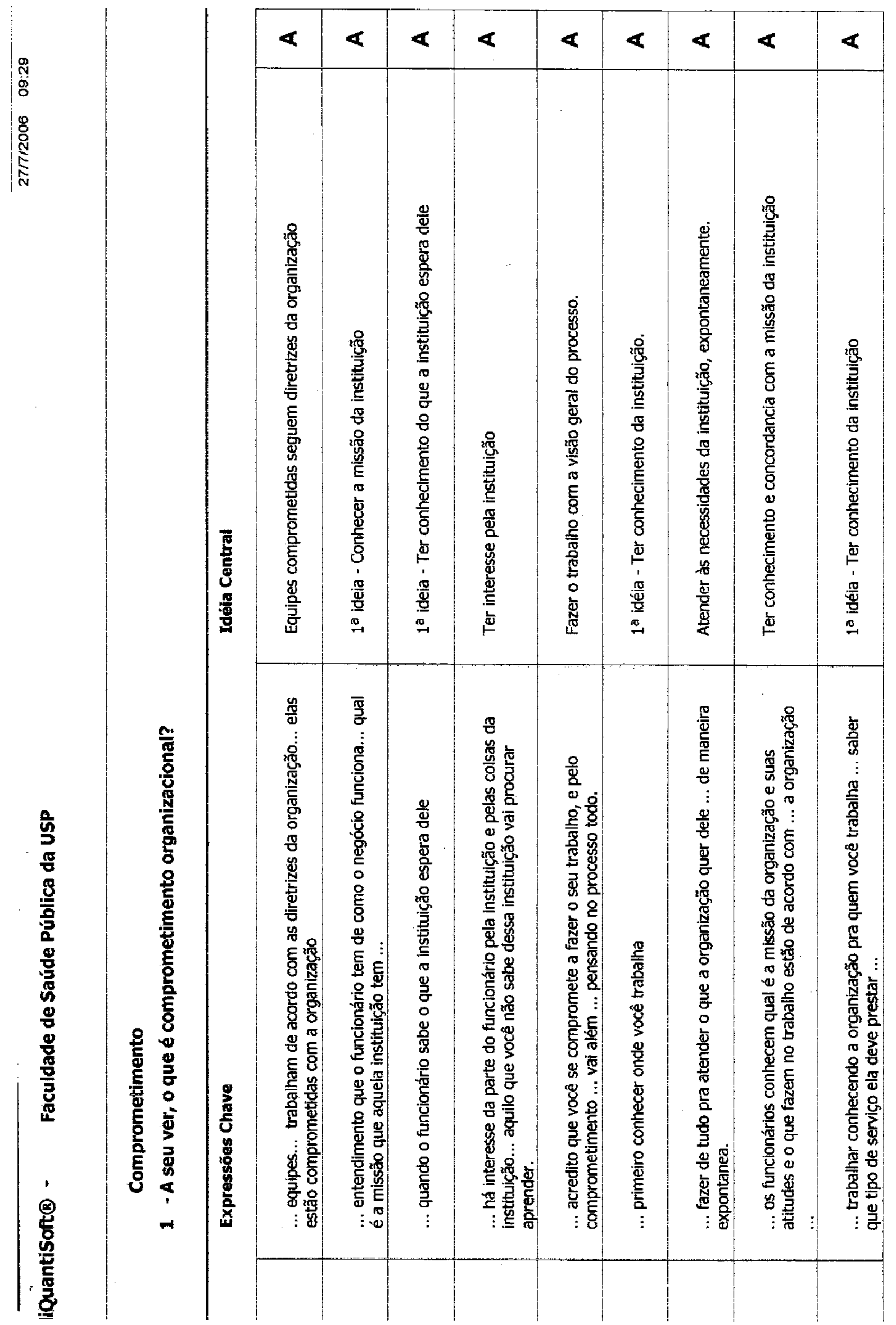




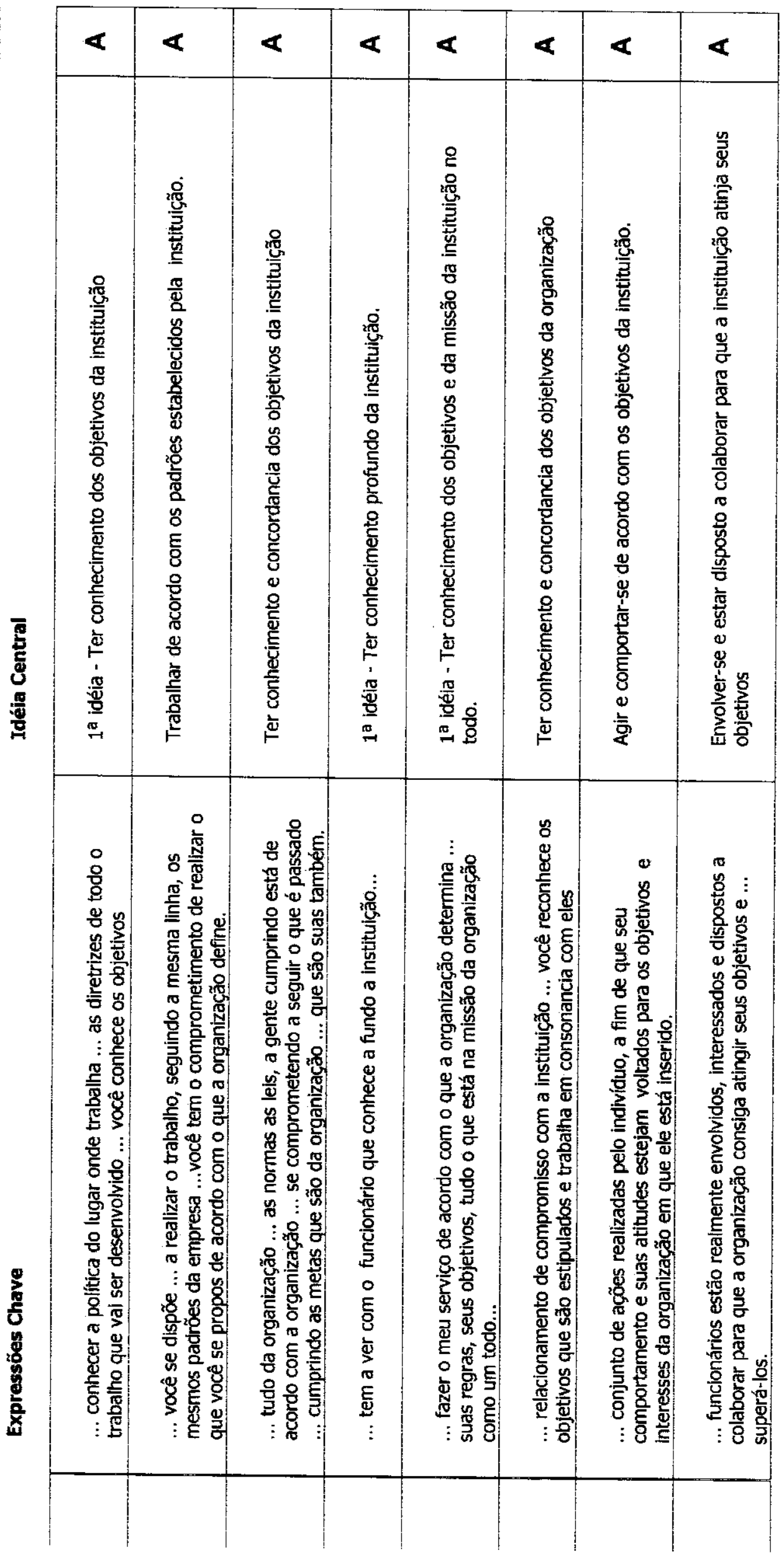




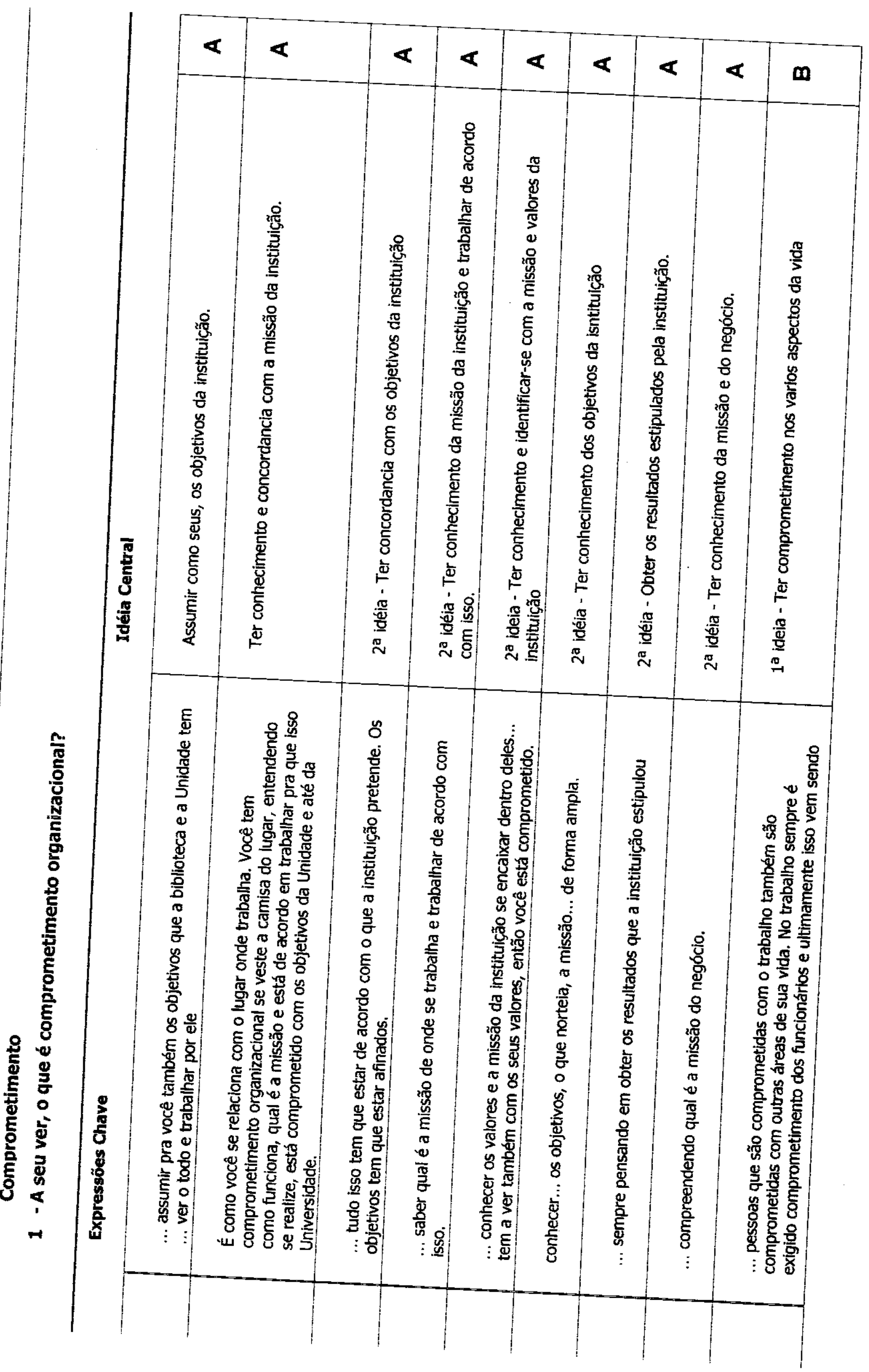




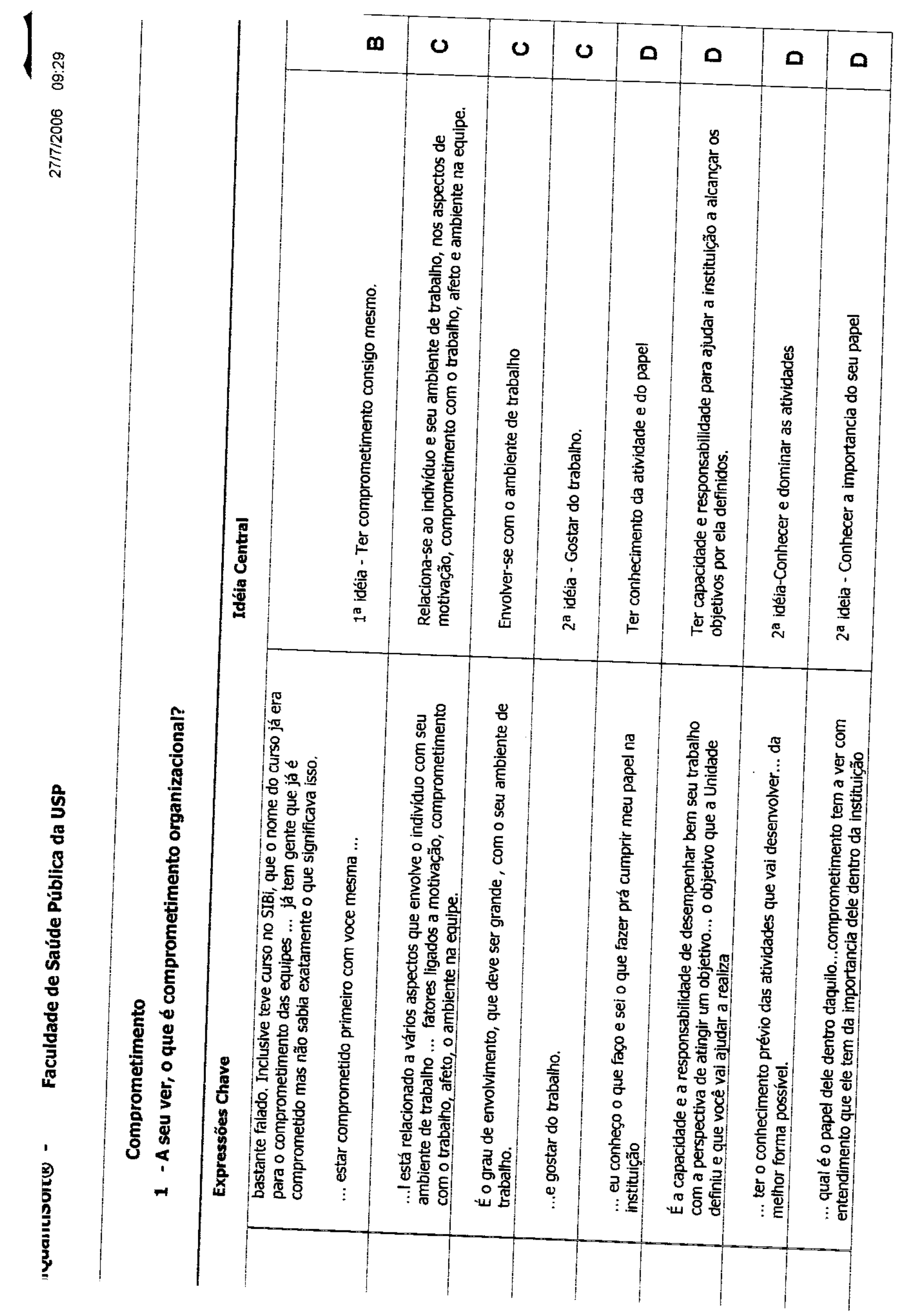




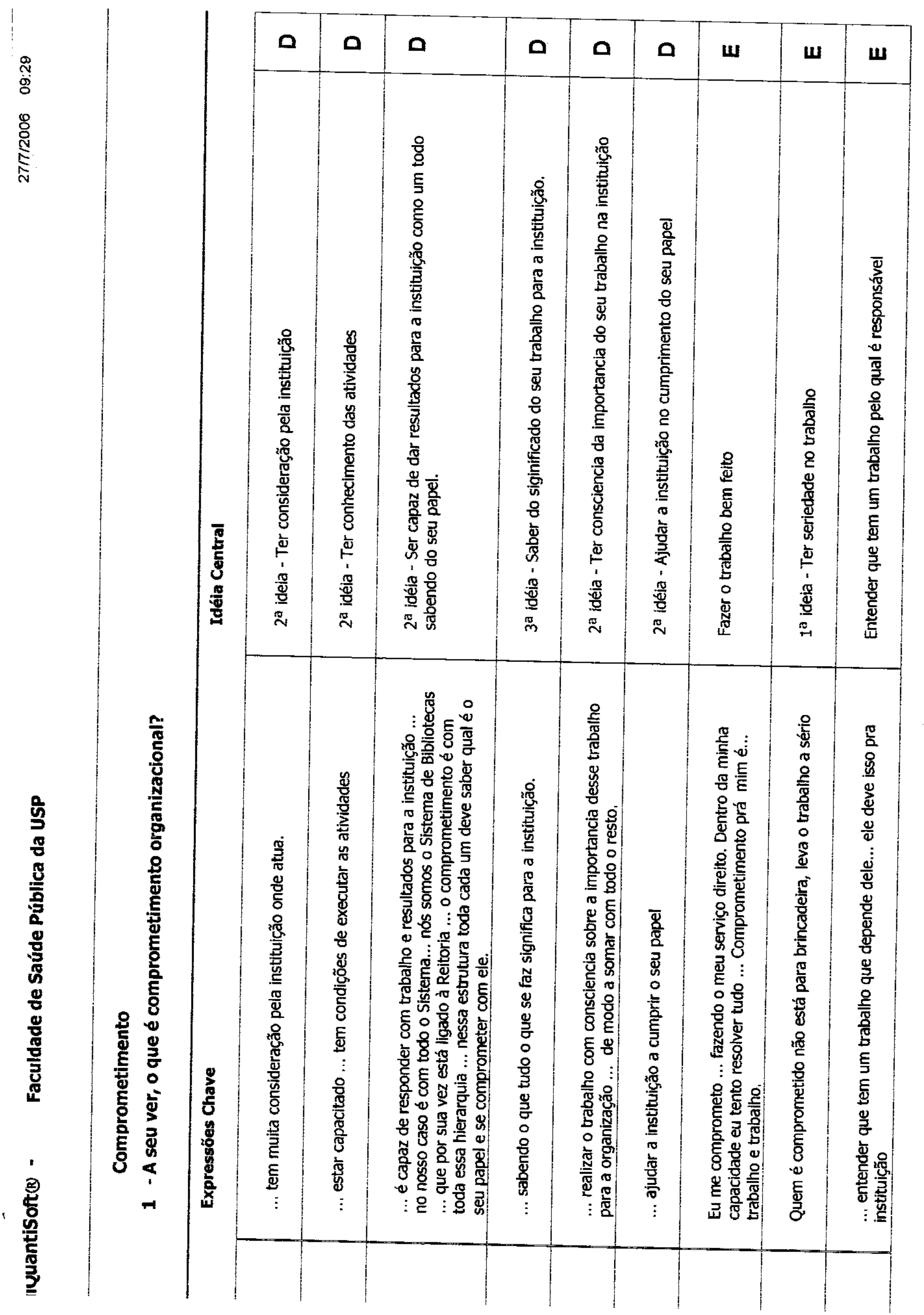




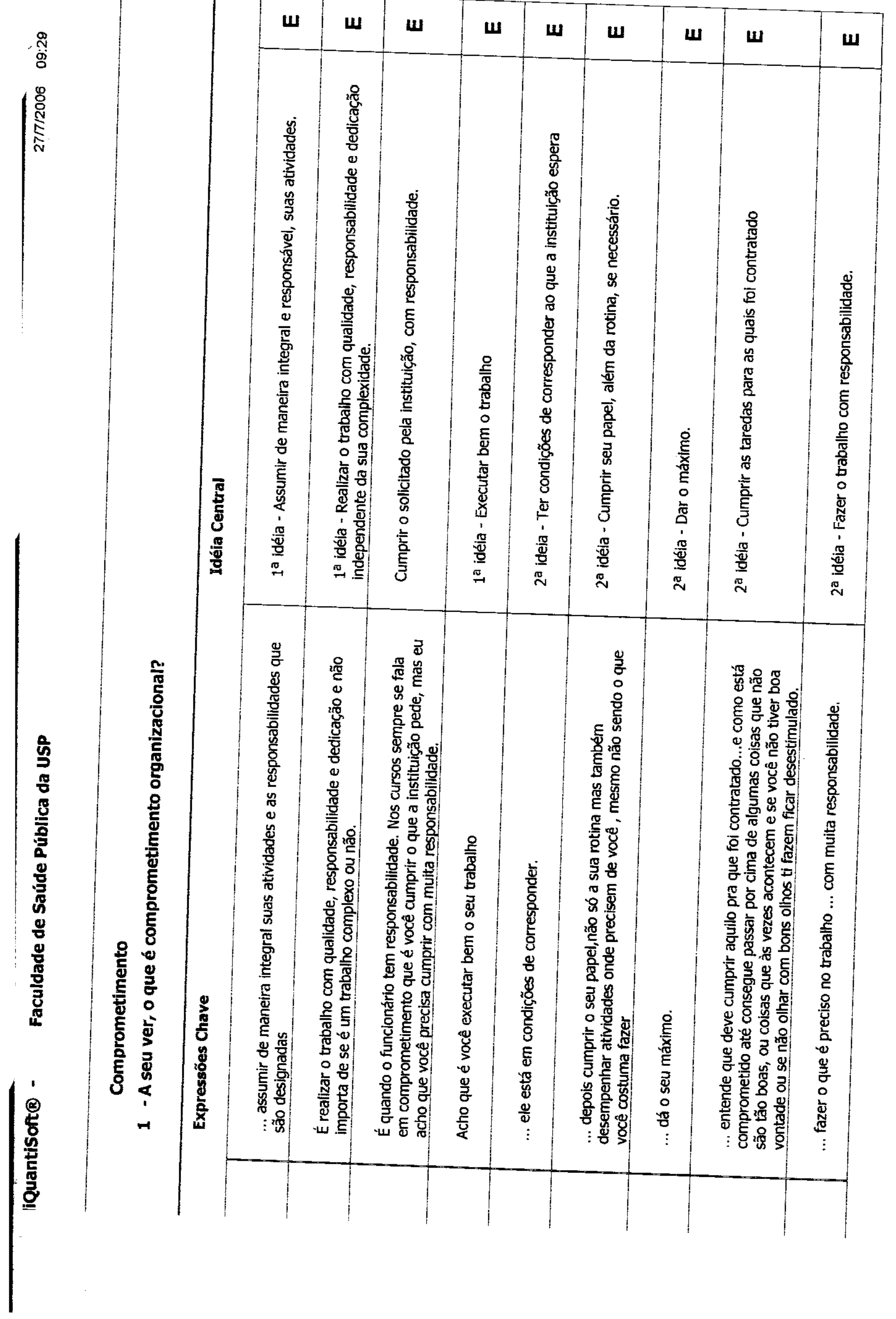




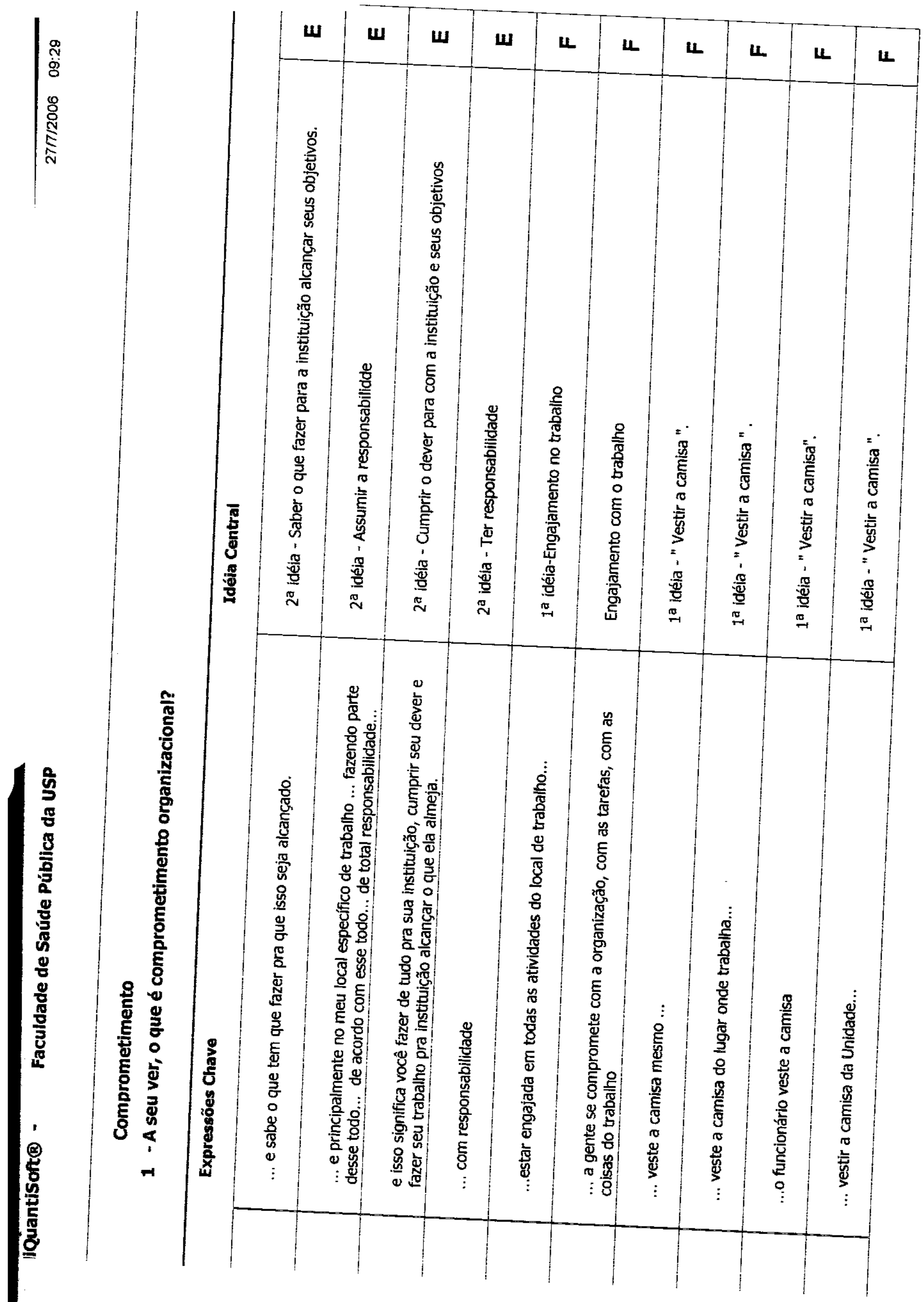




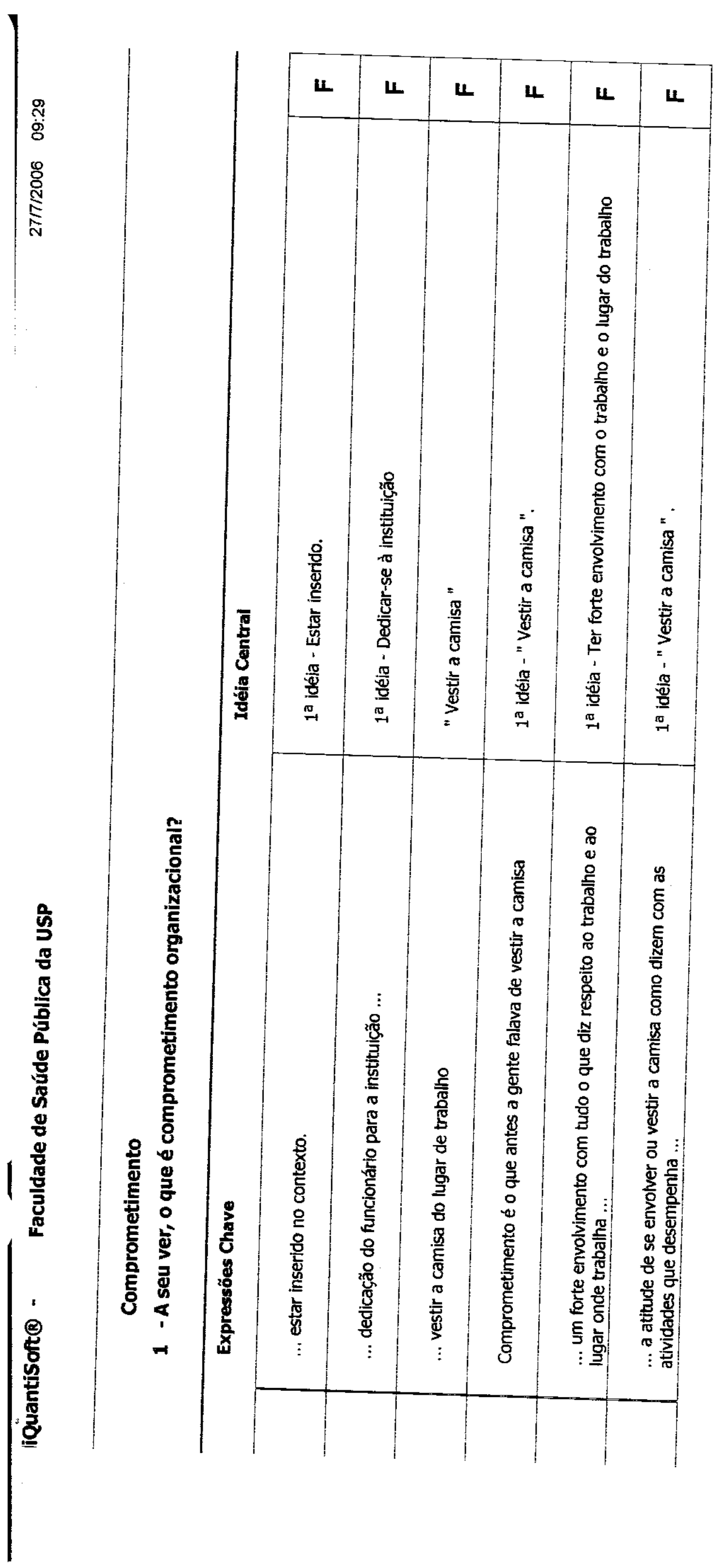




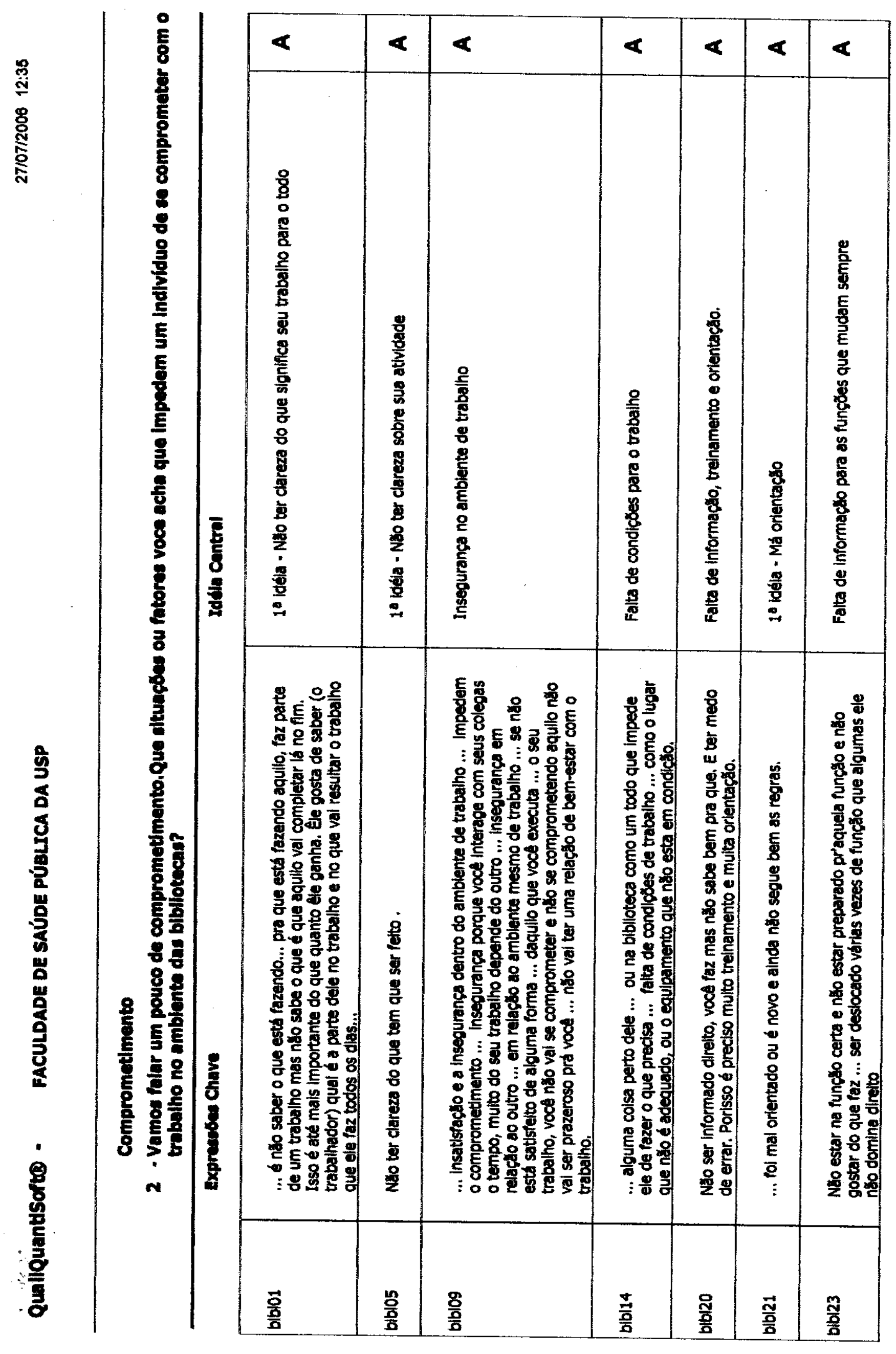




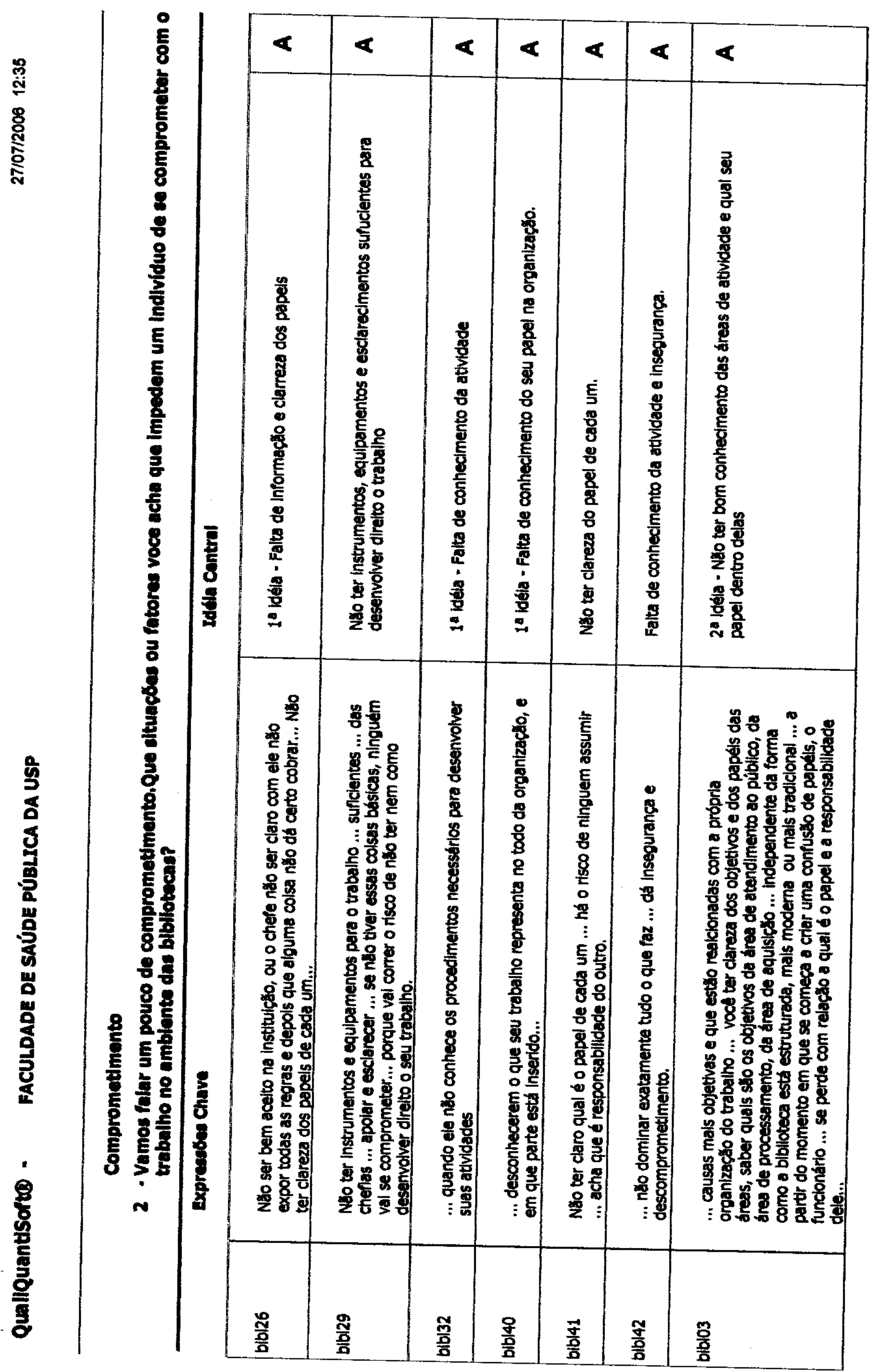




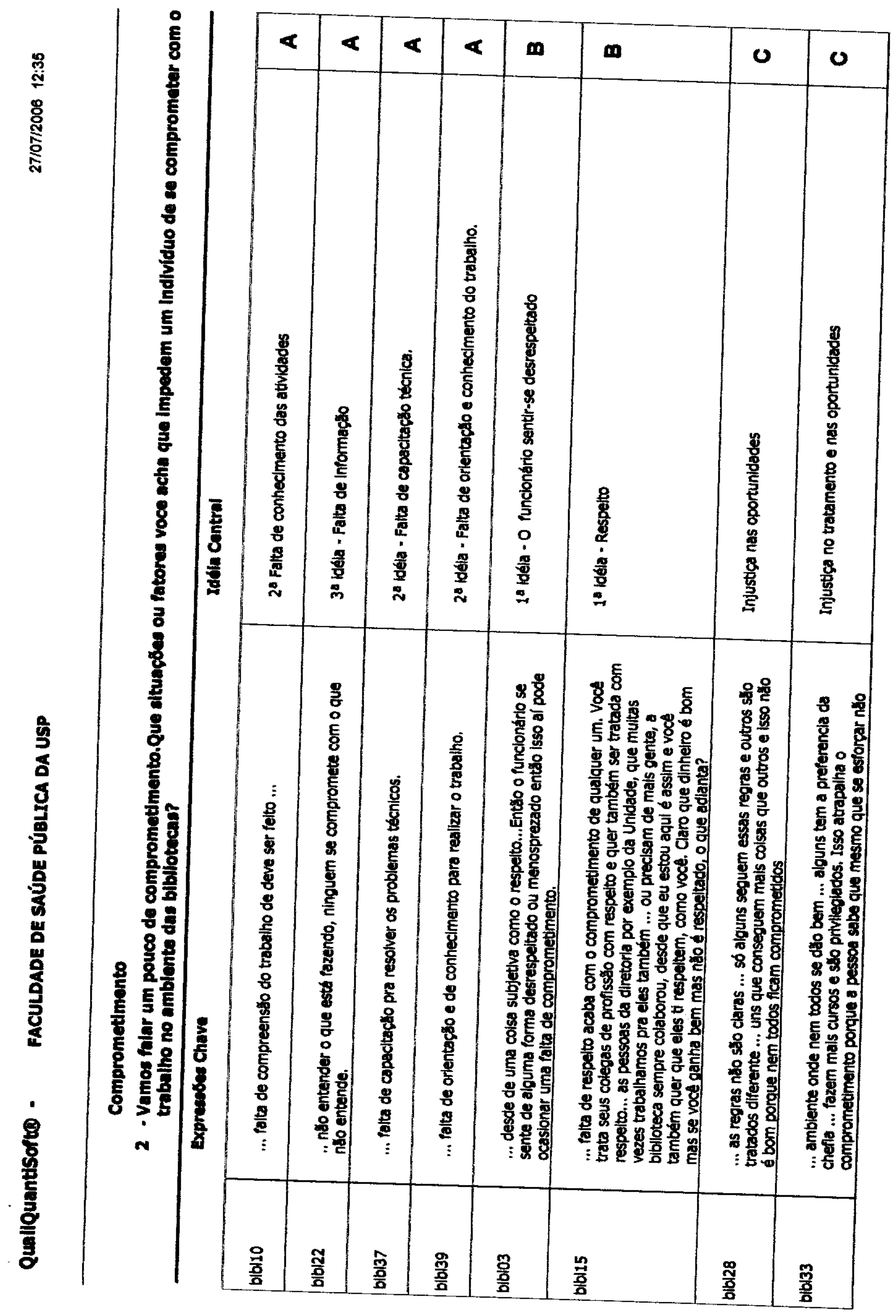




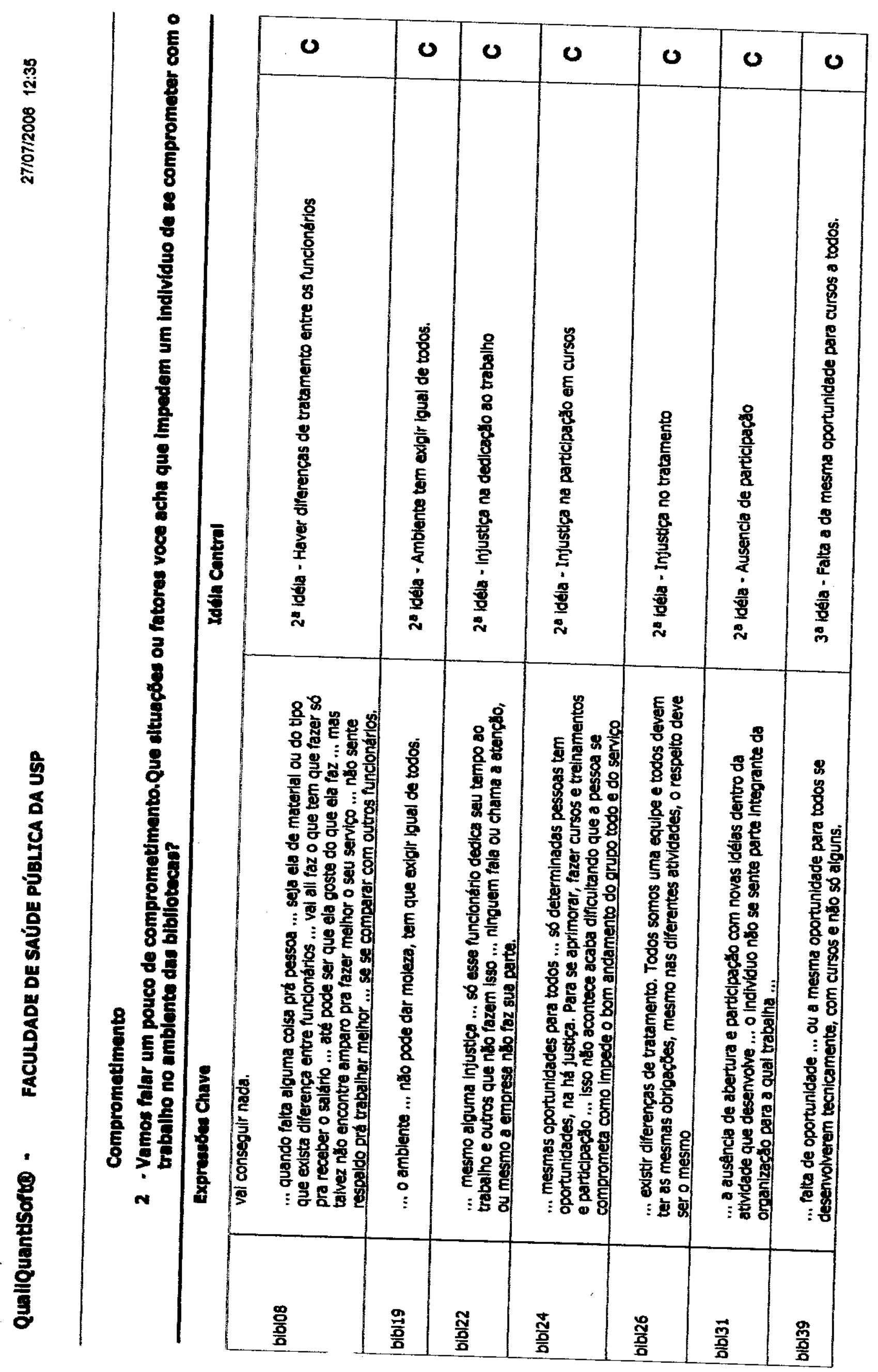




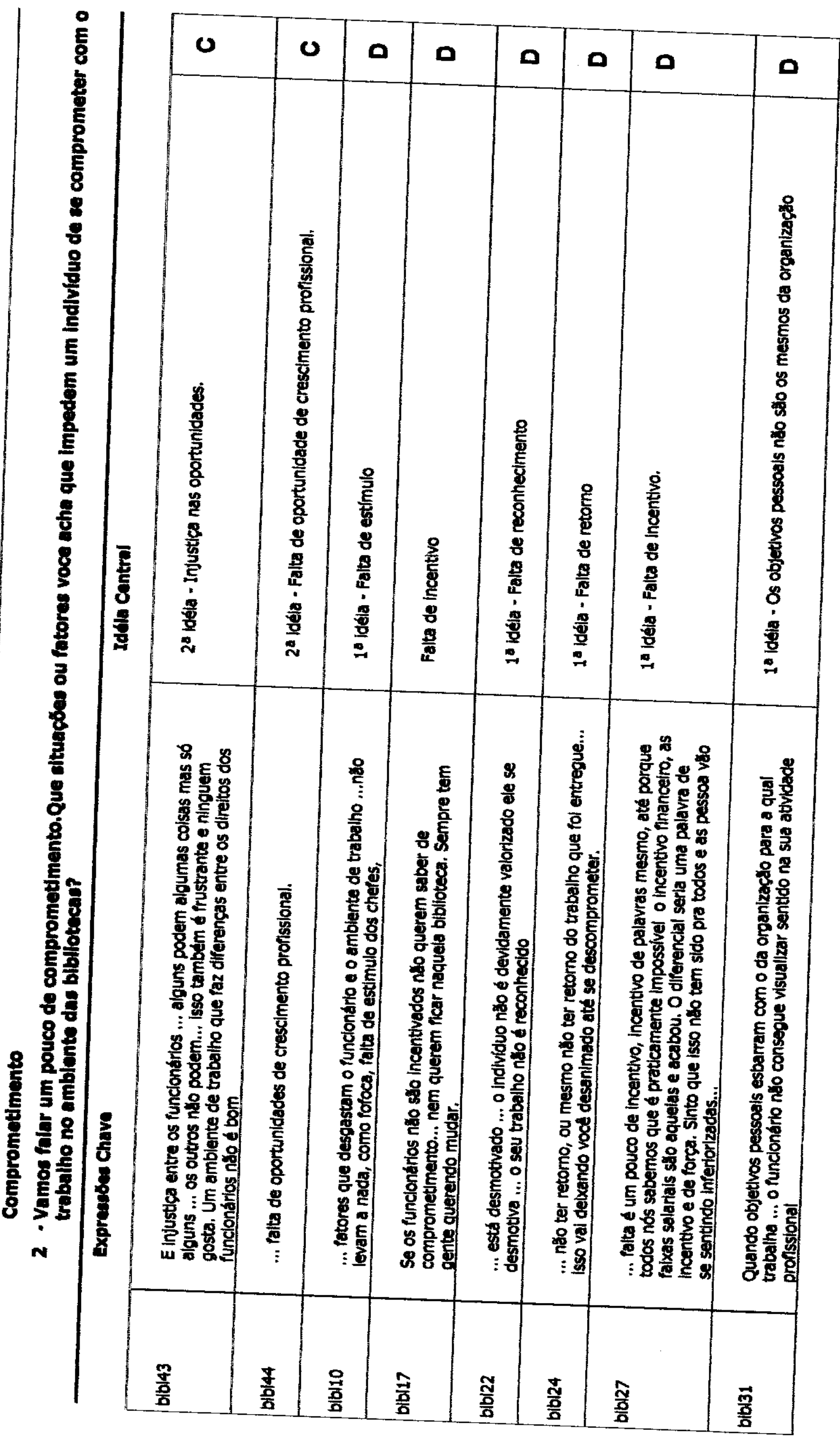




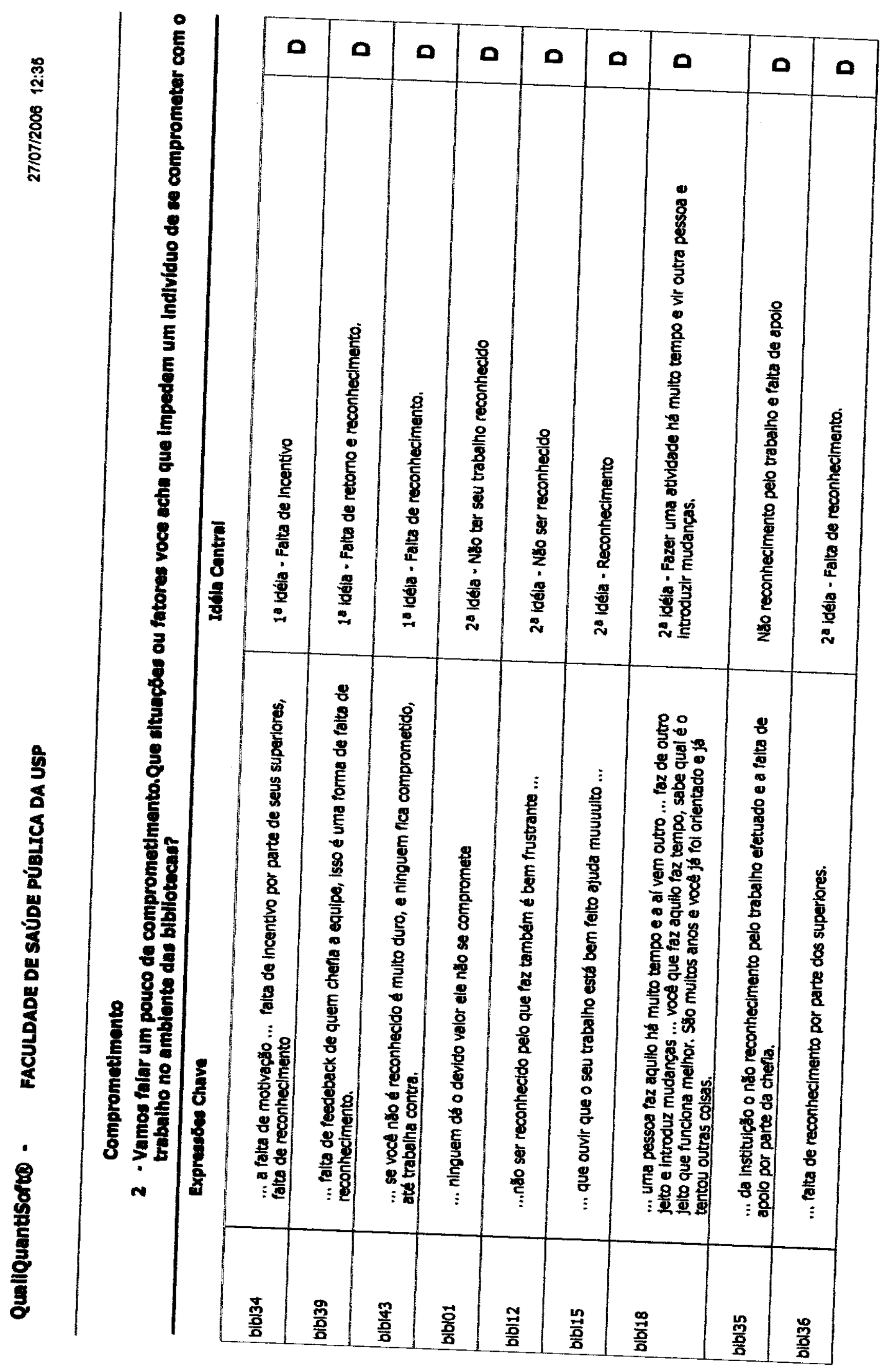




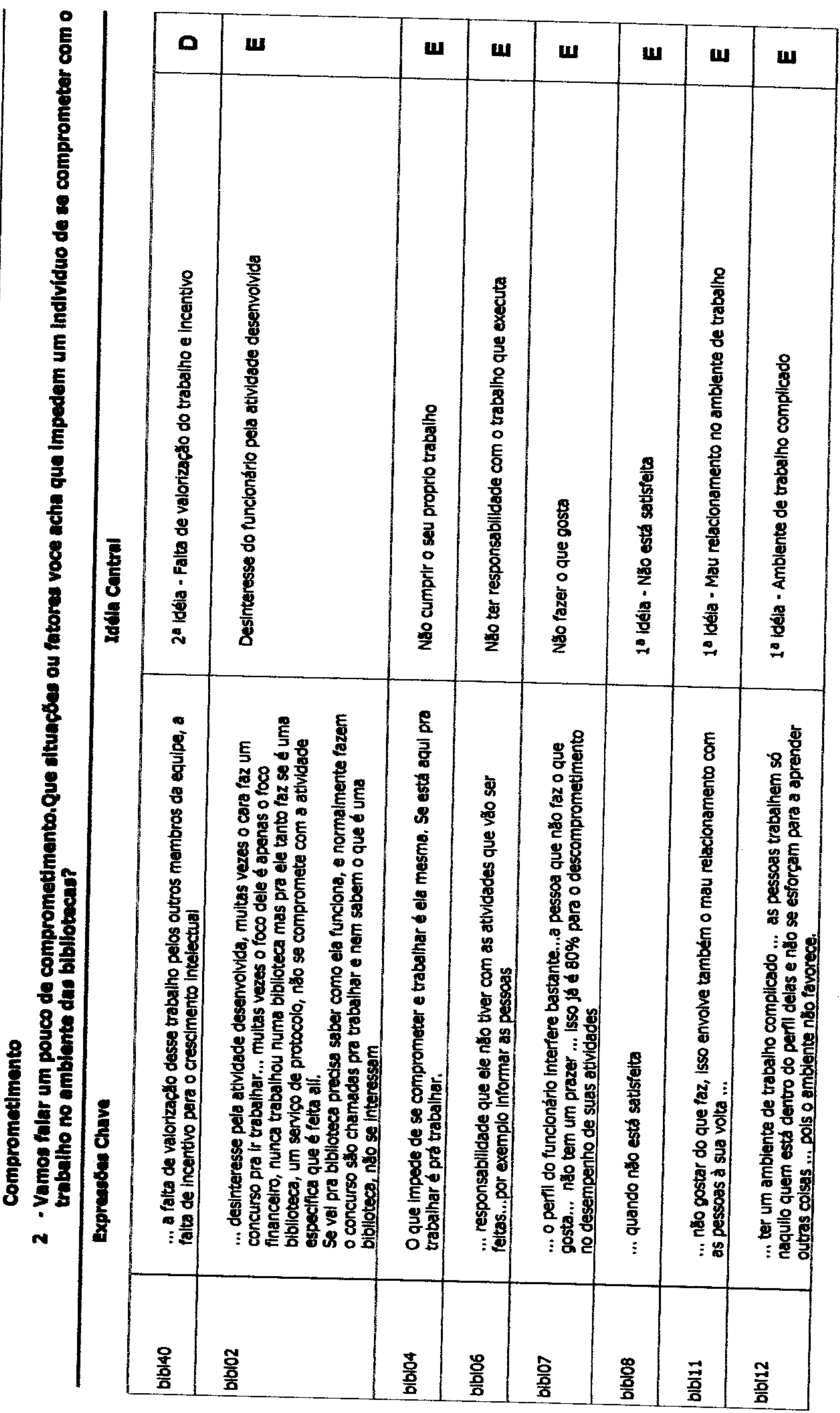




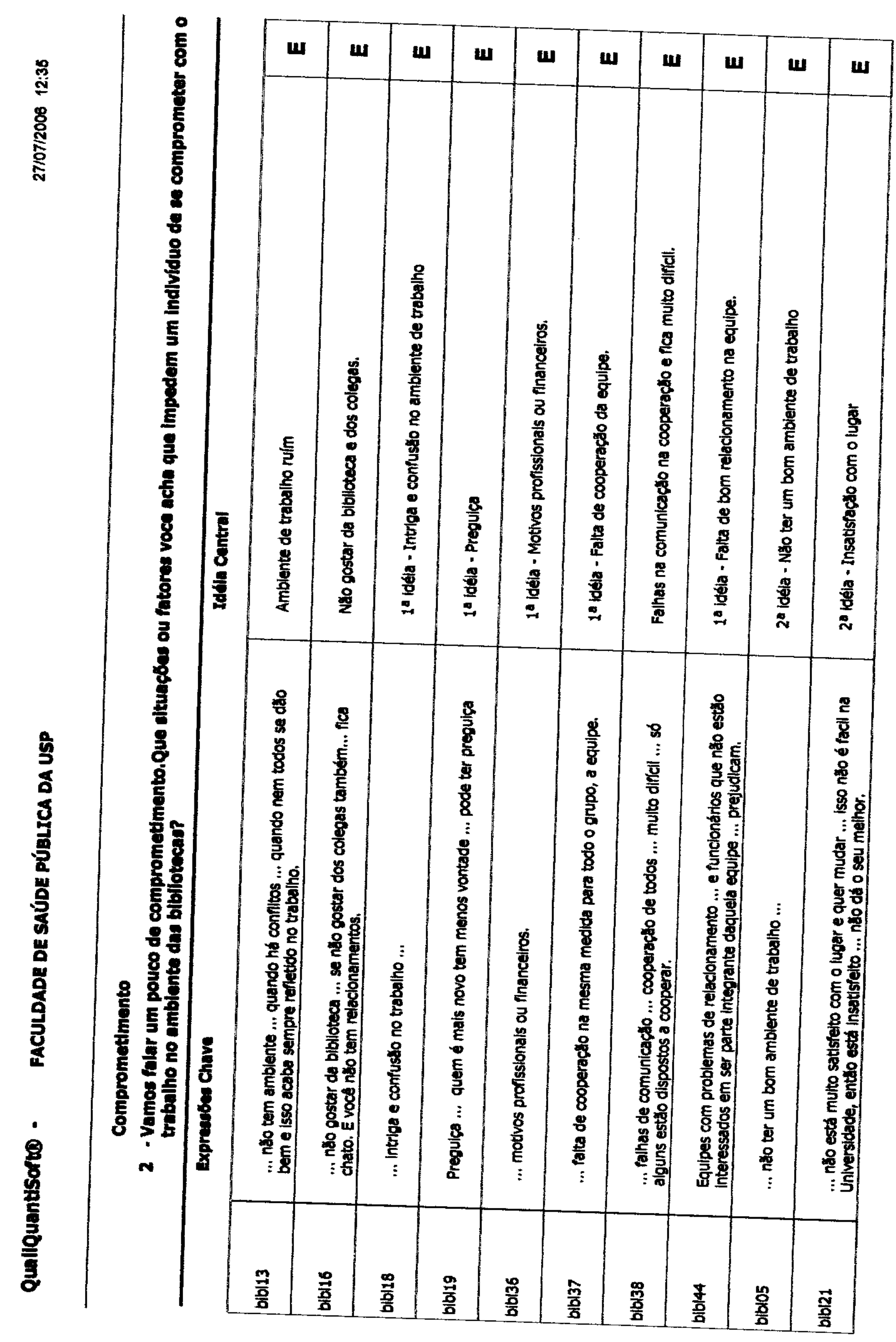




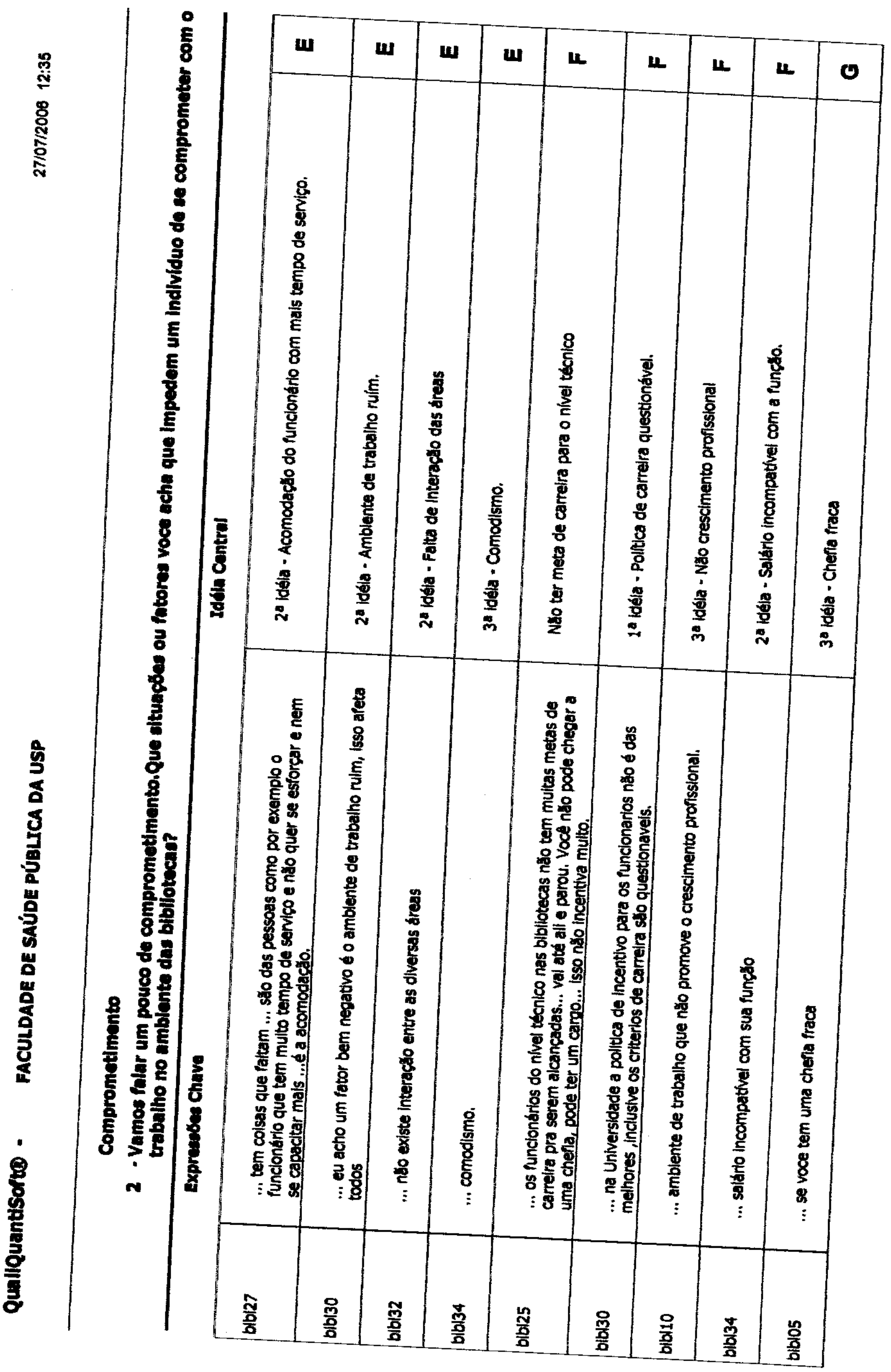




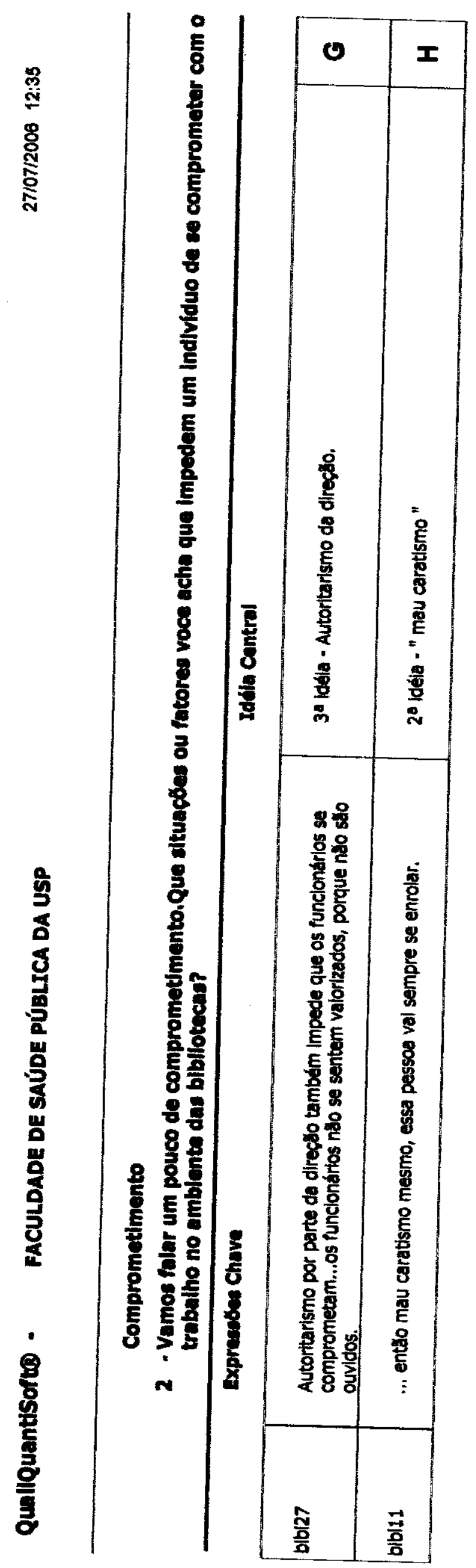




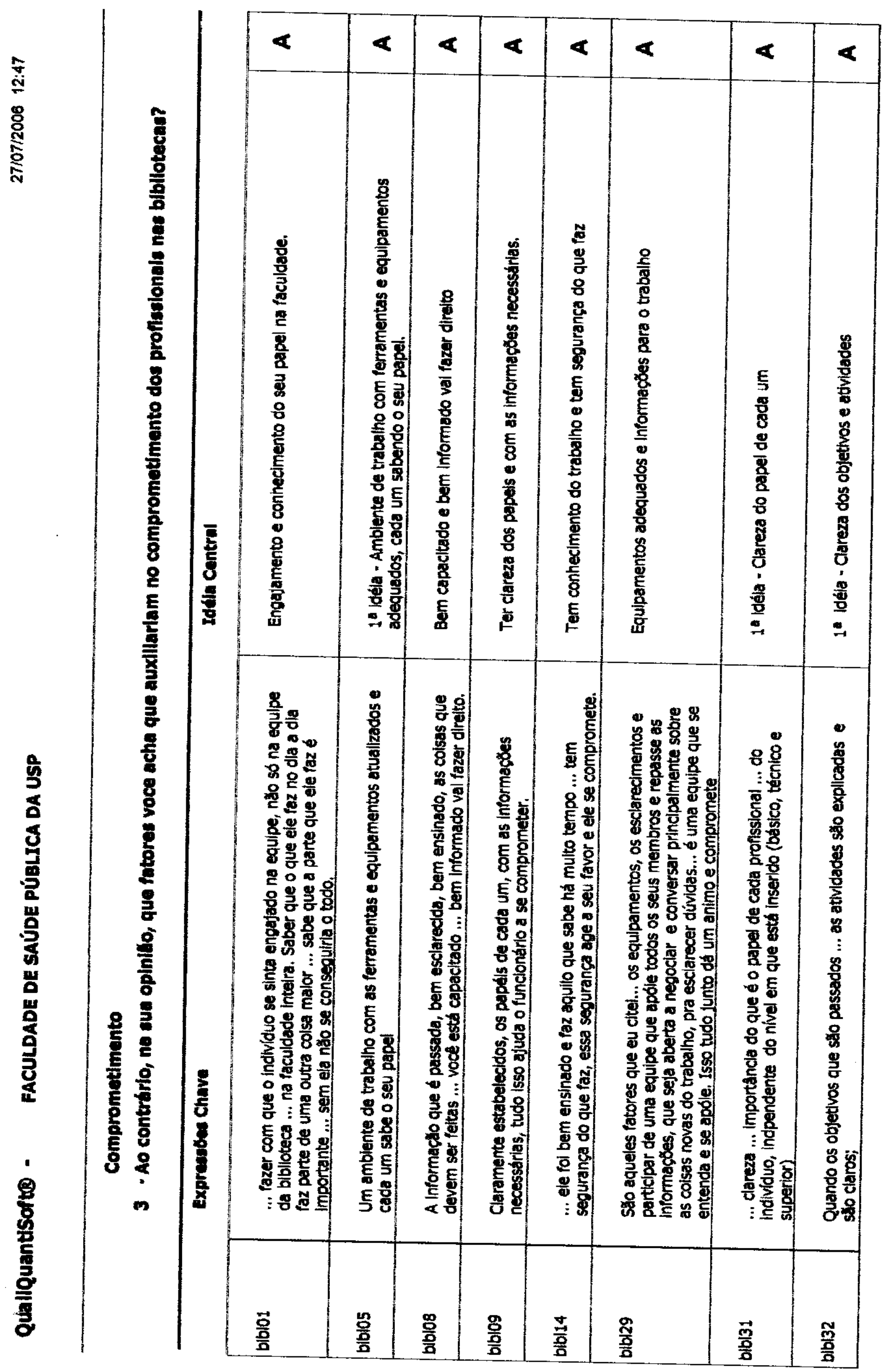




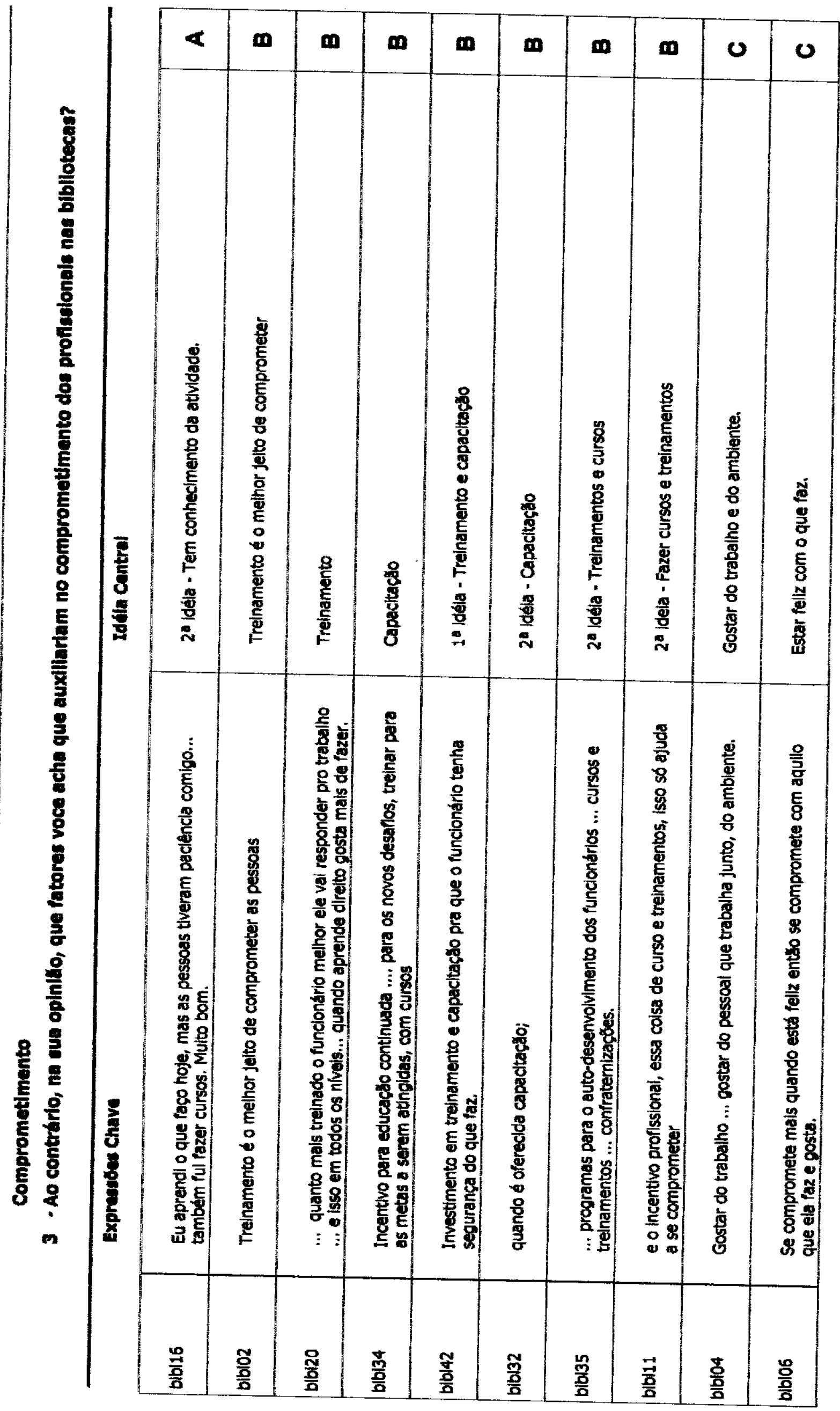

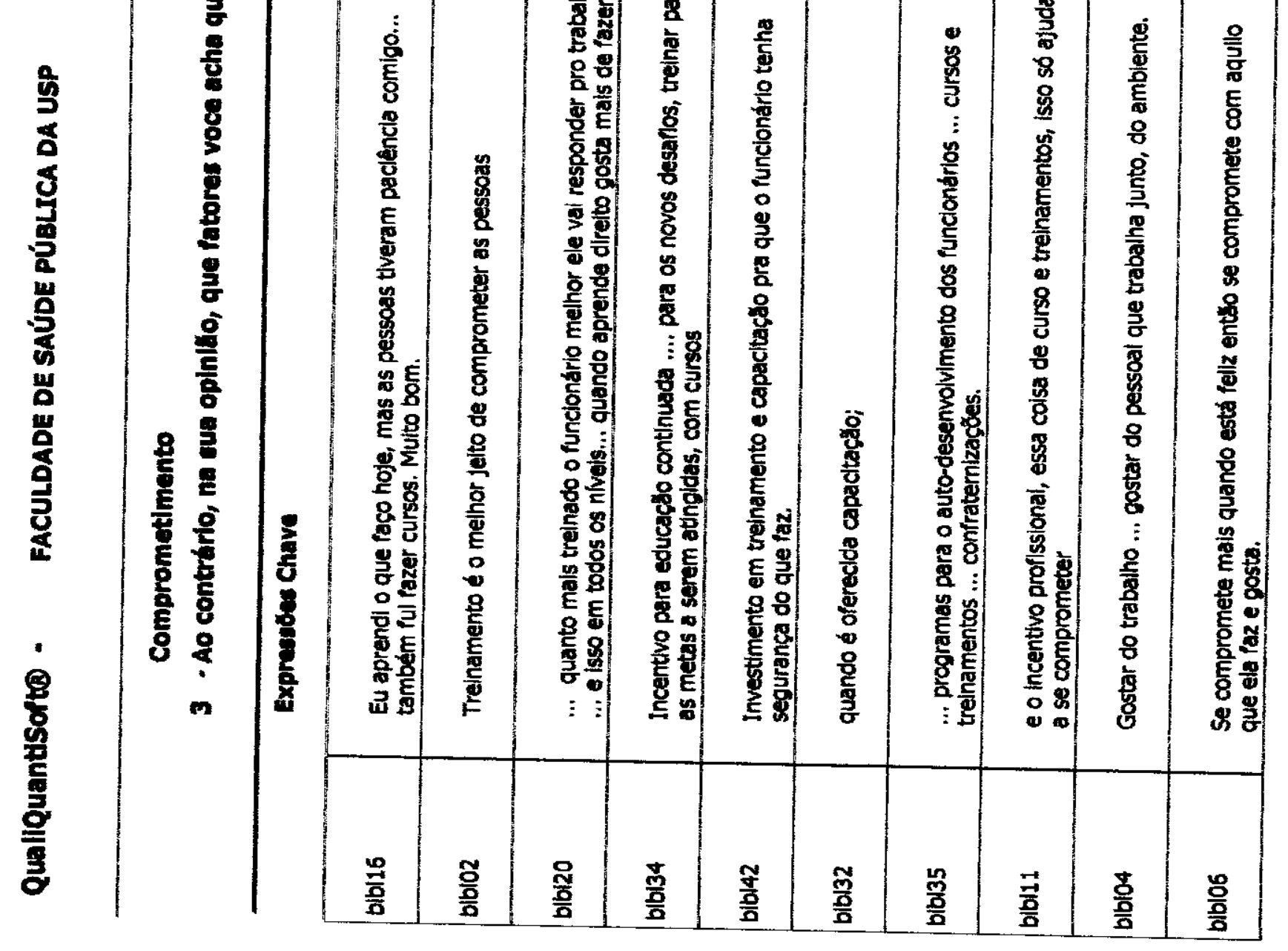




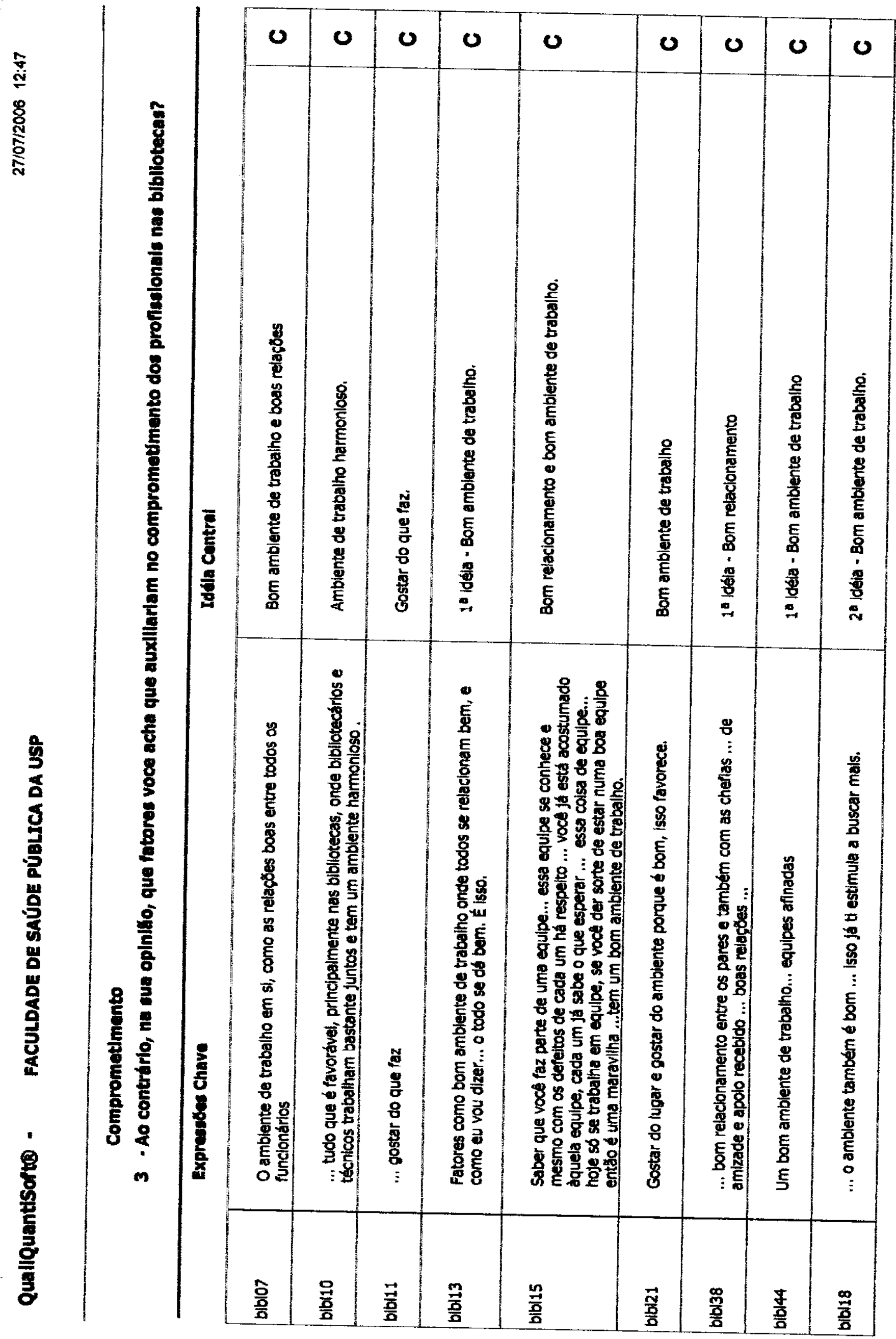




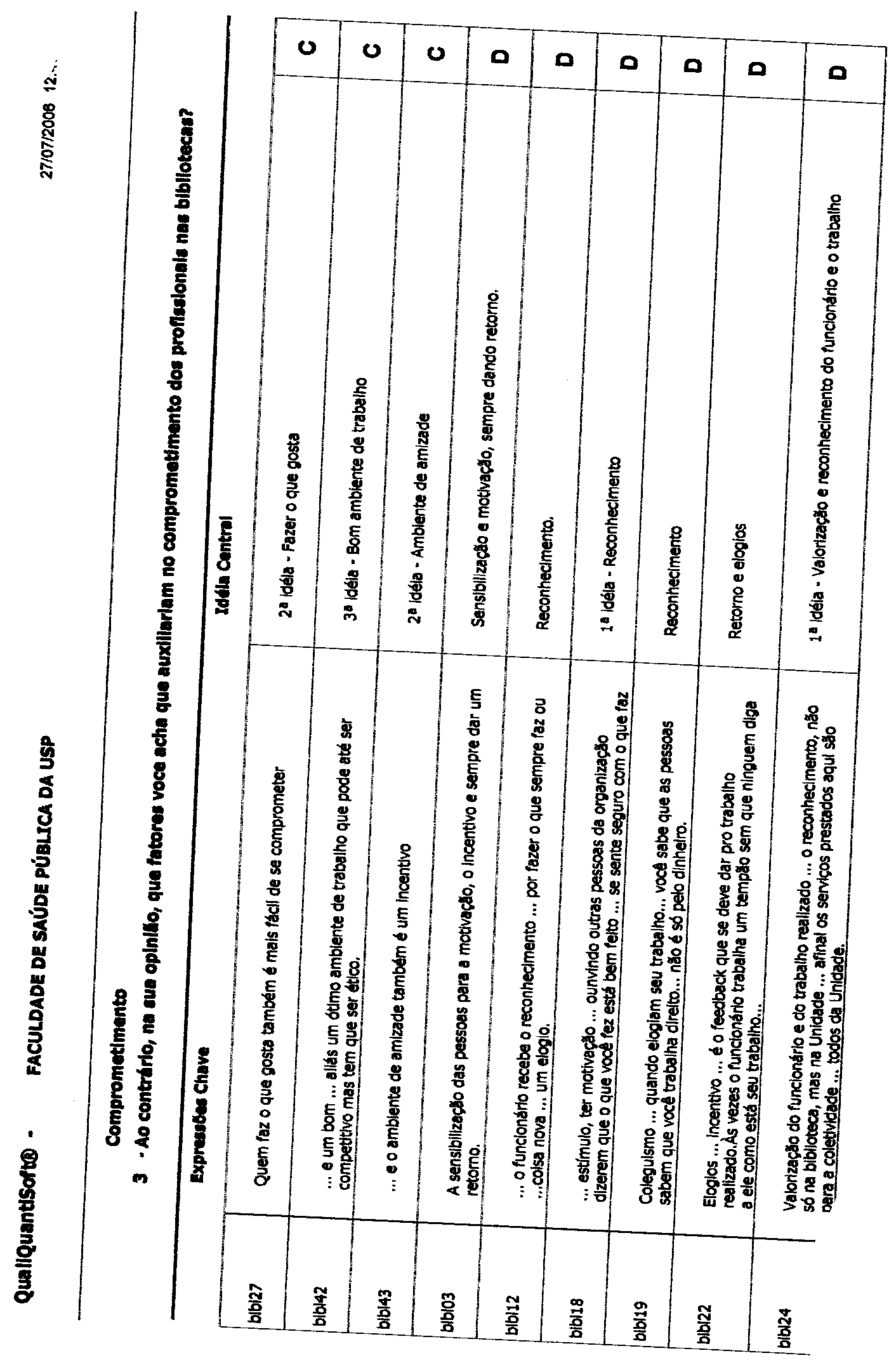




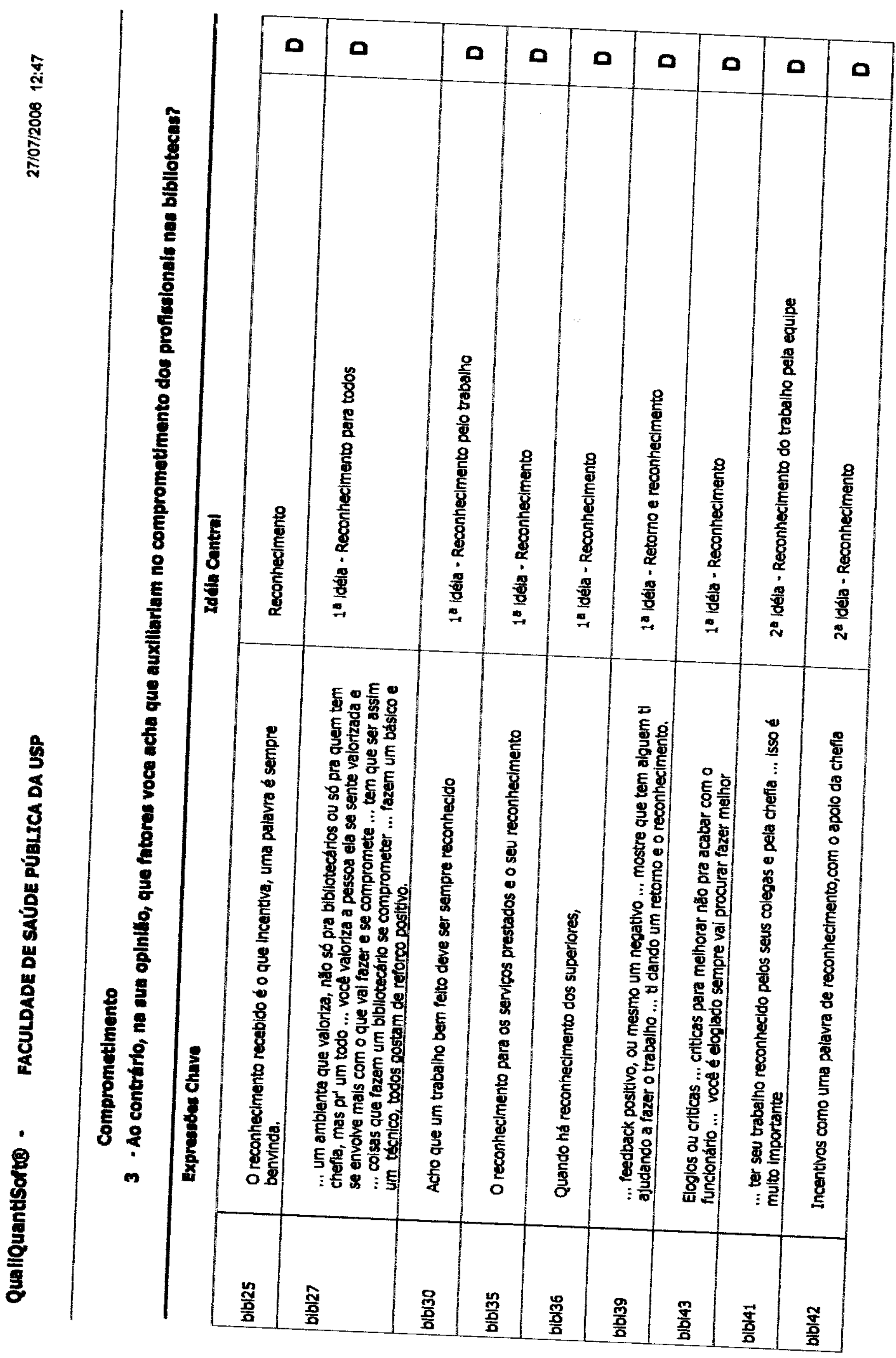




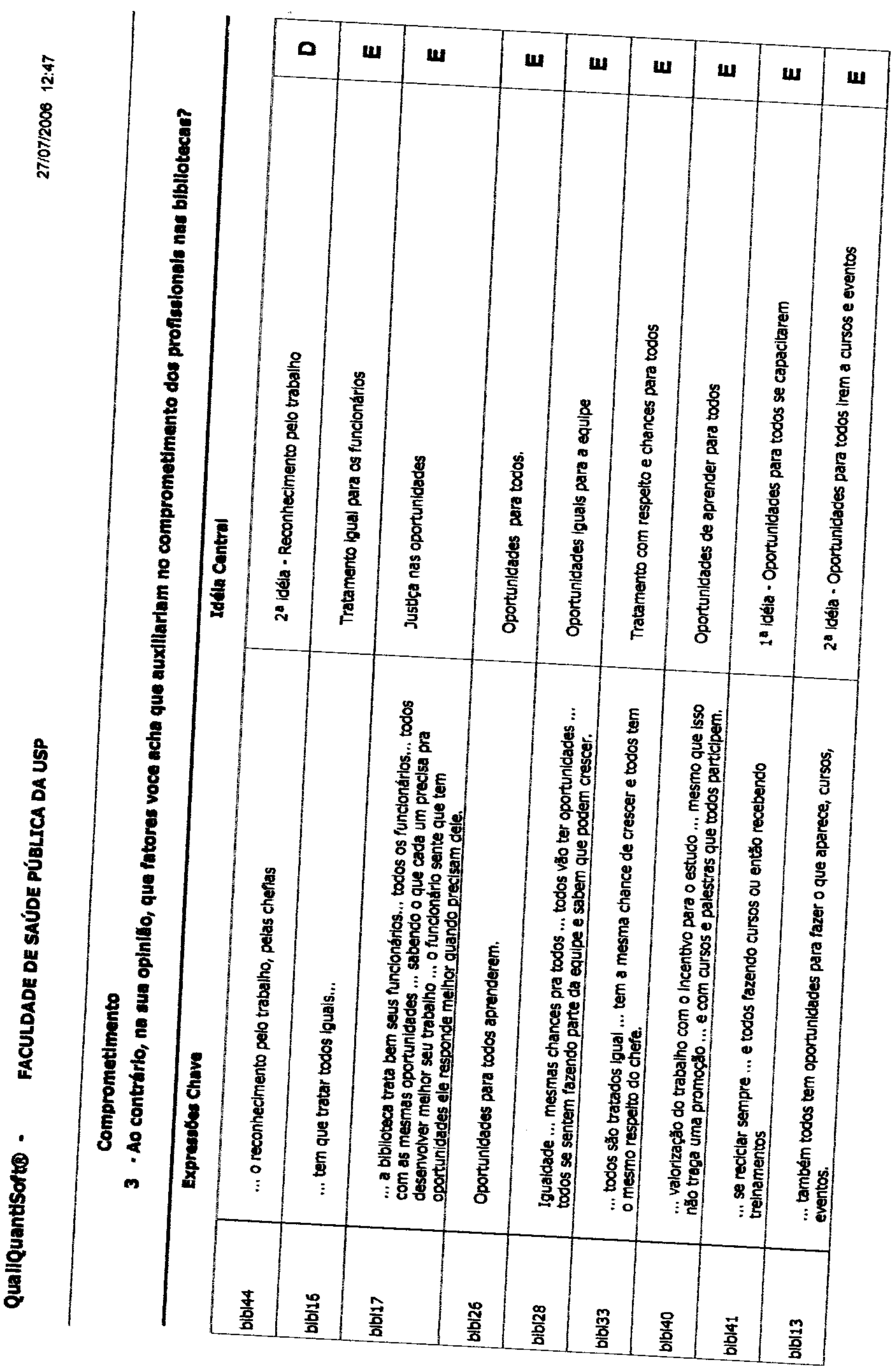




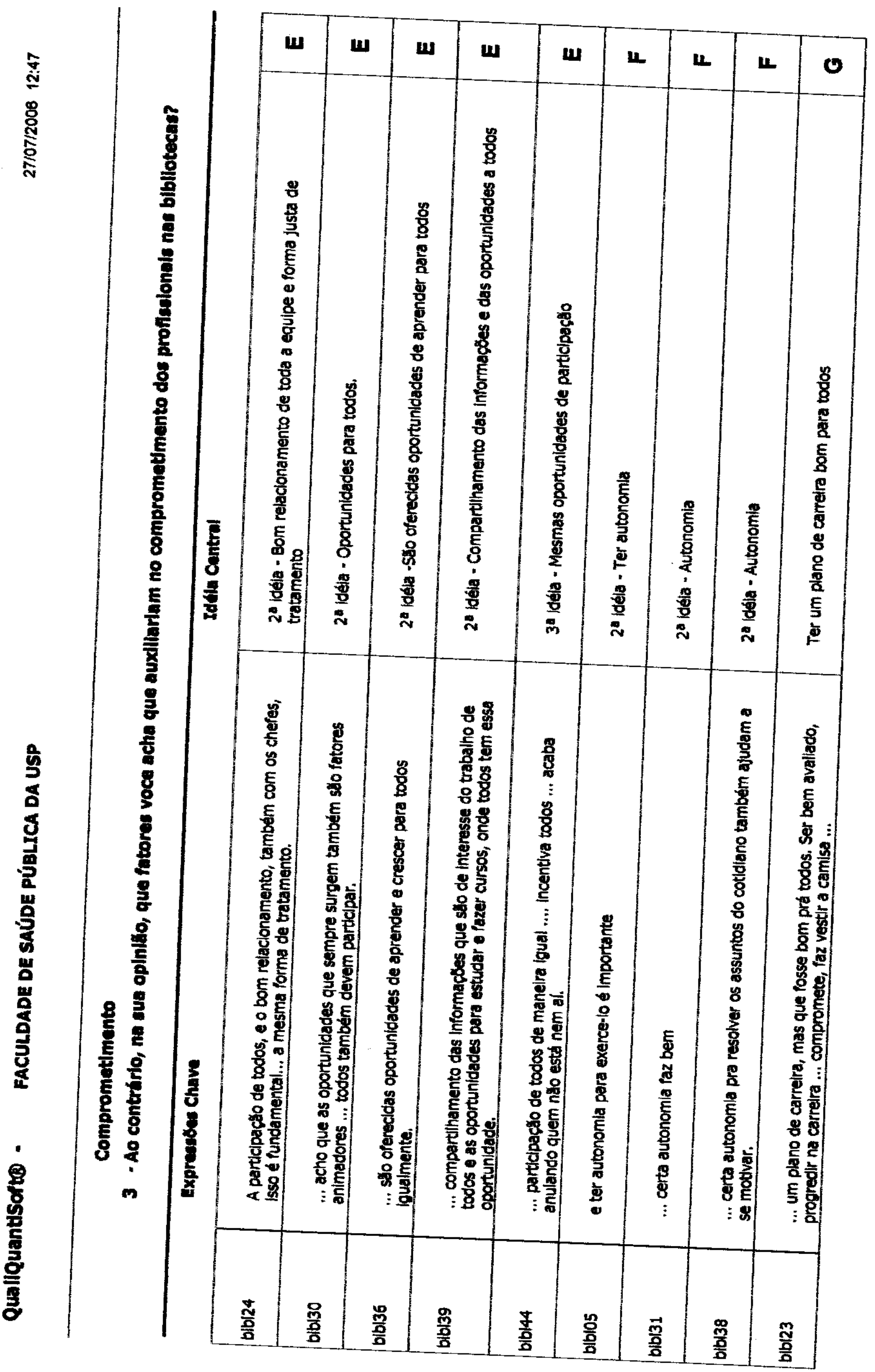




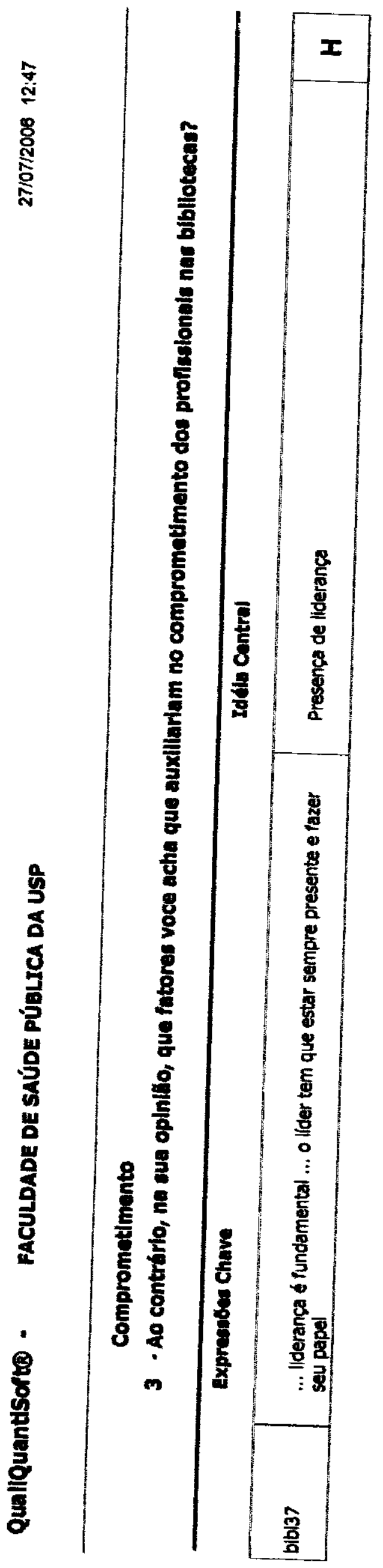




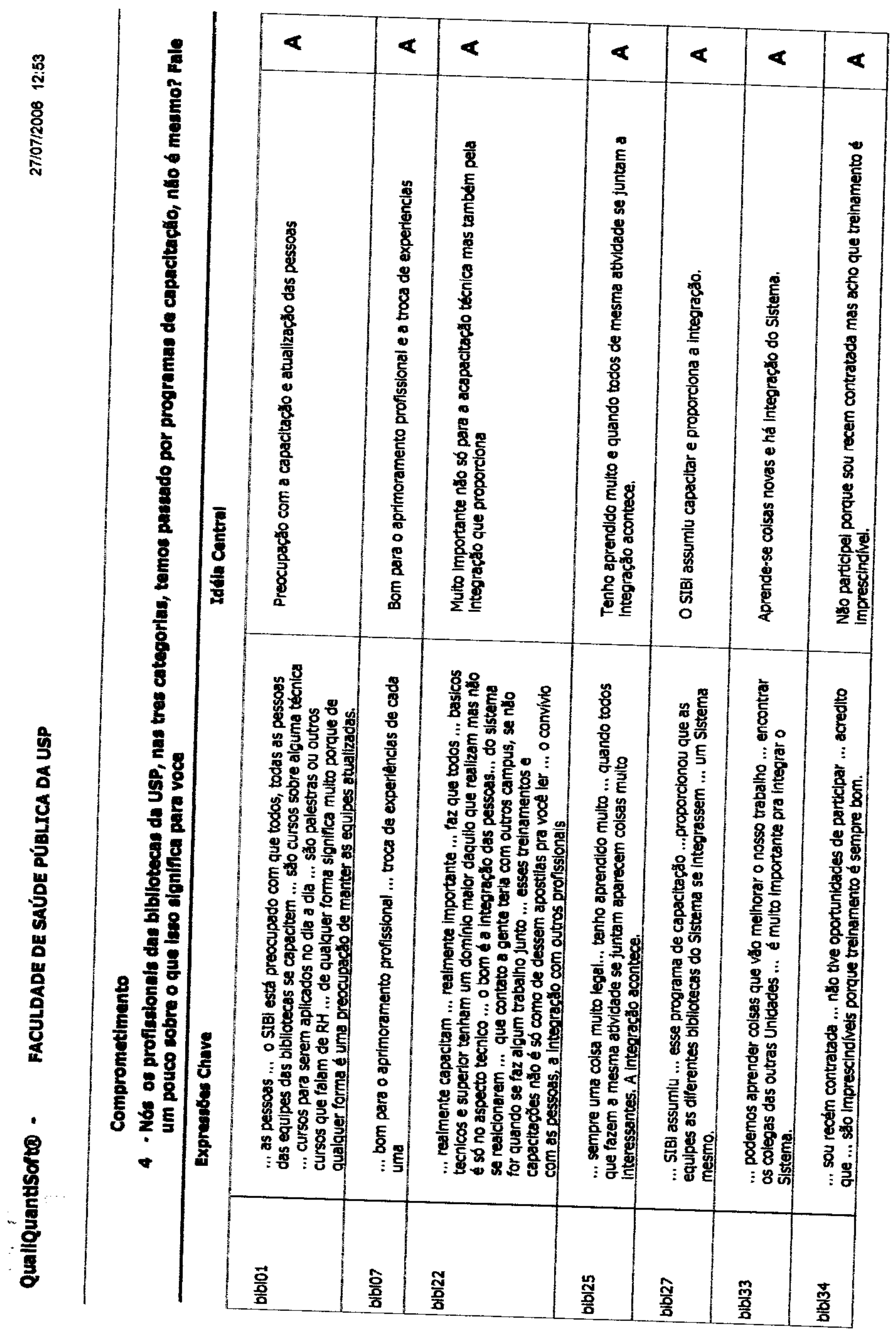




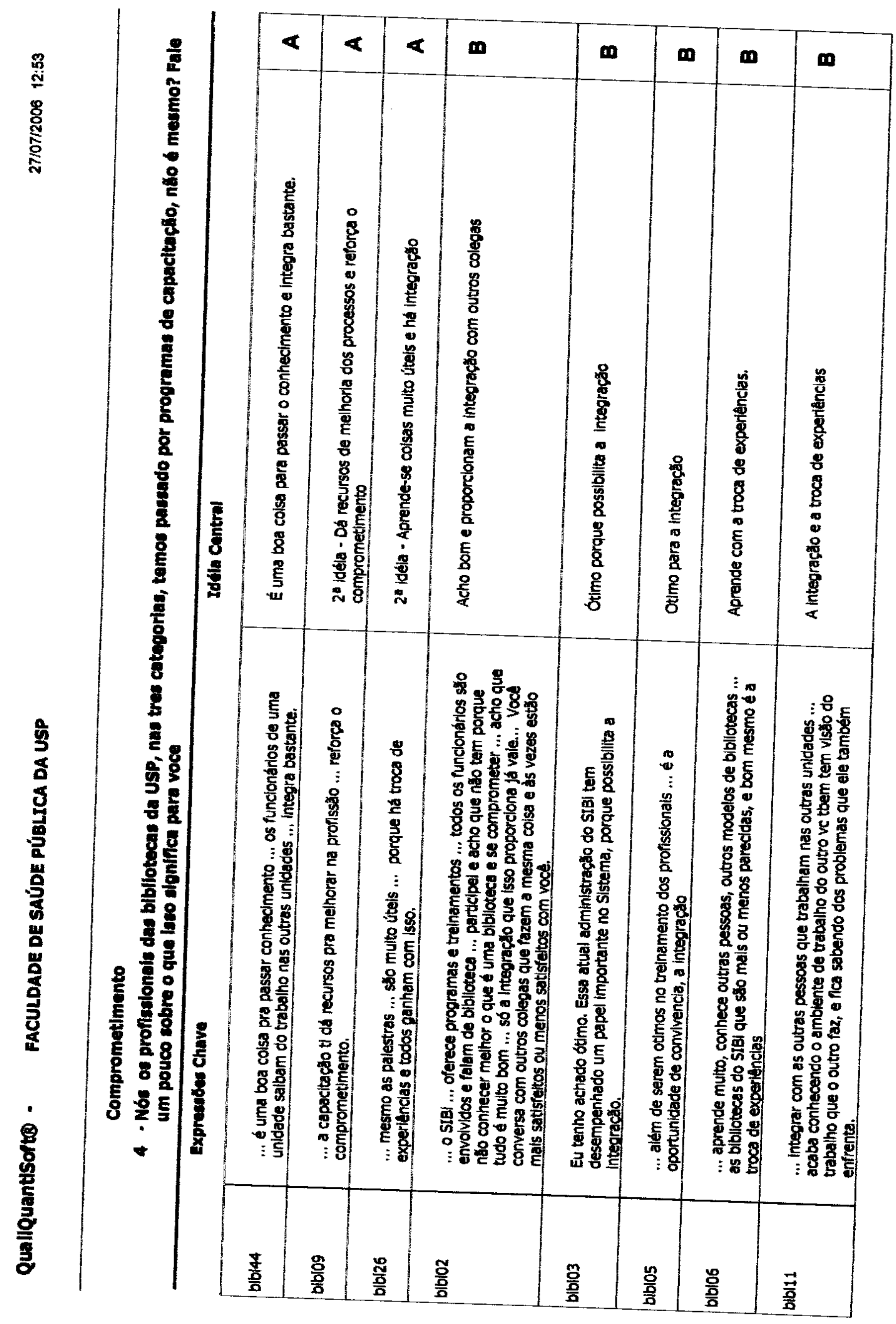




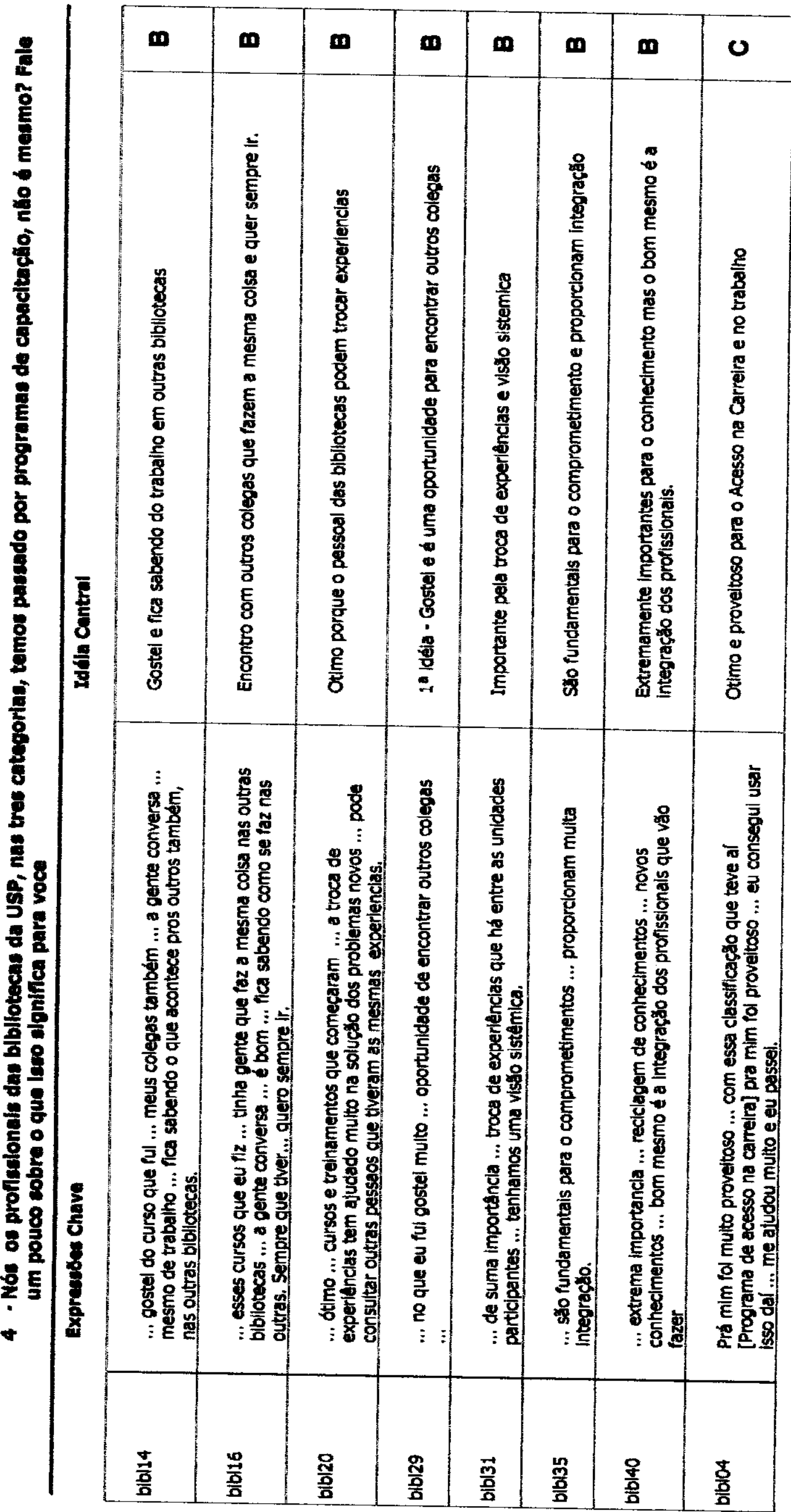




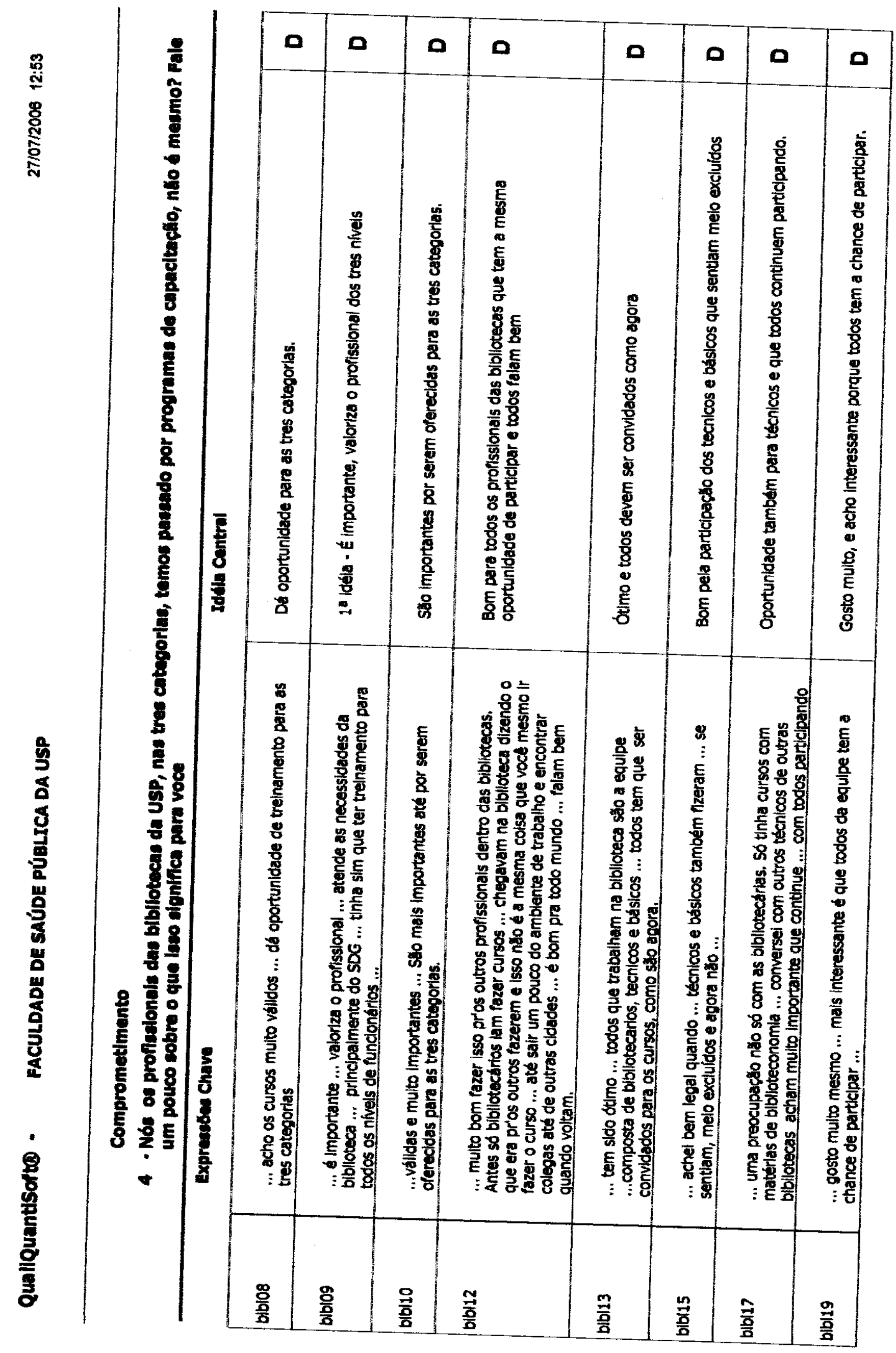




\begin{tabular}{|c|c|c|c|c|c|c|c|c|c|}
\hline \multirow[b]{2}{*}{ 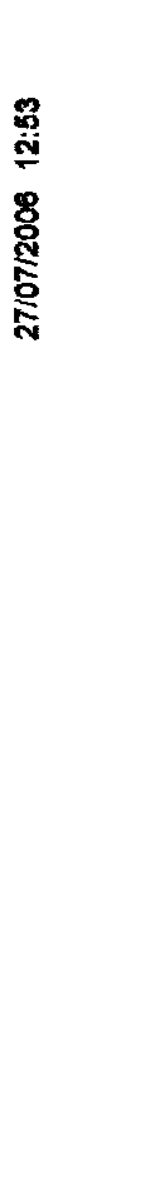 } & & 0 & 0 & D & 0 & 0 & 0 & $w$ & $\boldsymbol{\omega}$ \\
\hline & 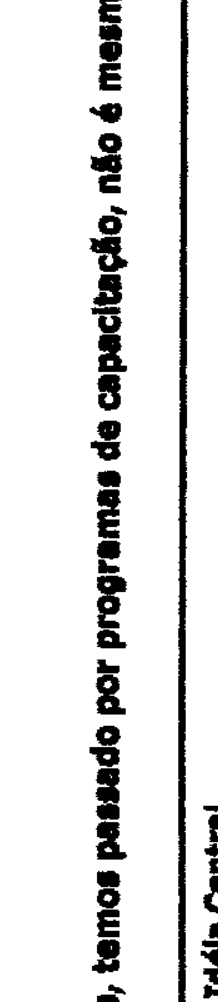 & 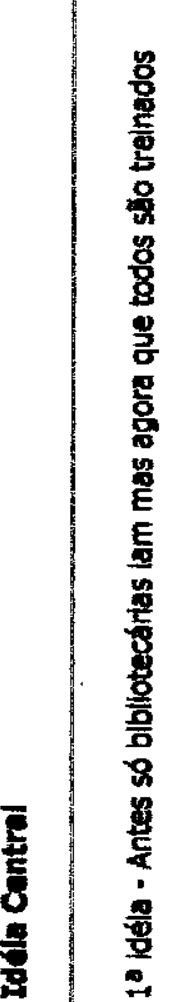 & 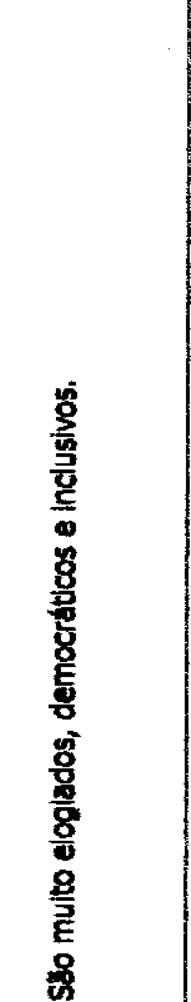 & 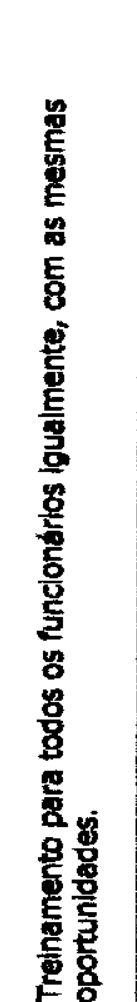 & 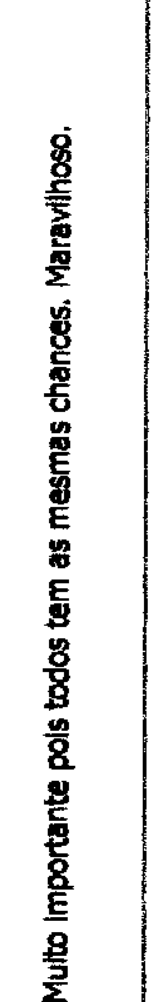 & 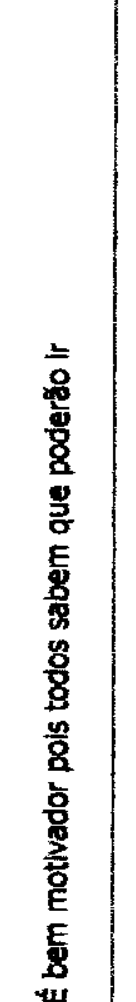 & 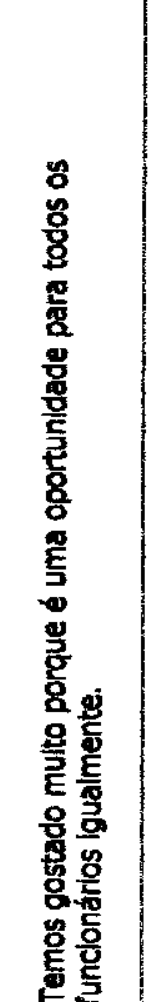 & 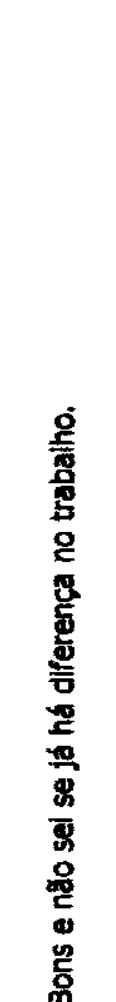 & 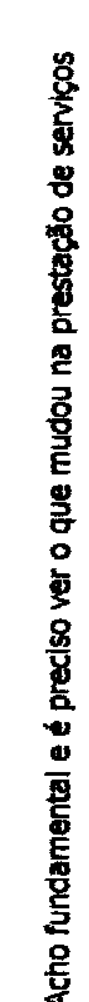 \\
\hline \multirow[t]{2}{*}{ 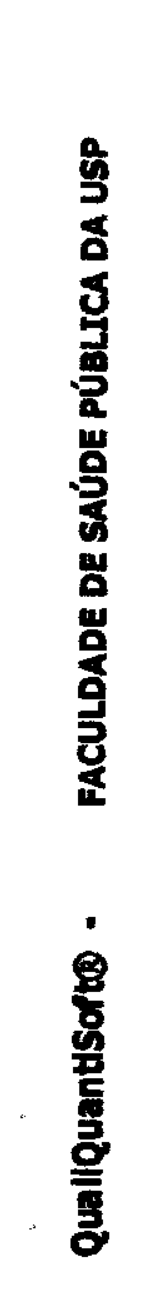 } & 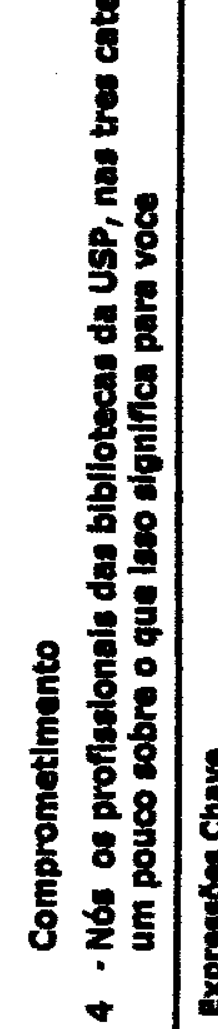 & 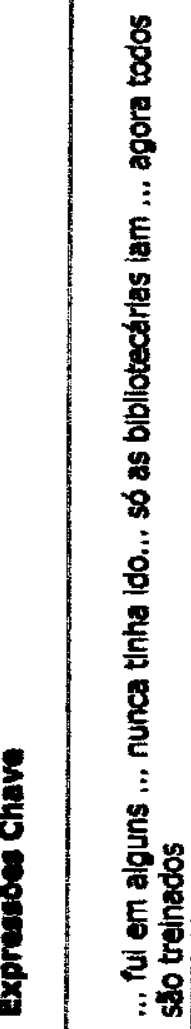 & 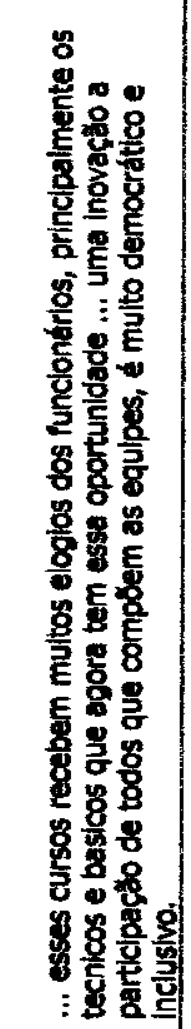 & 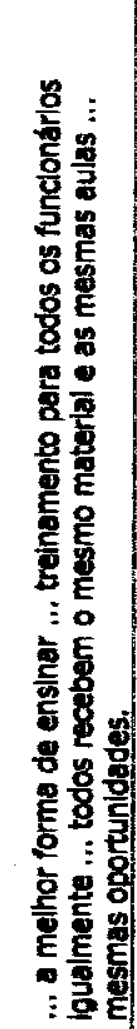 & 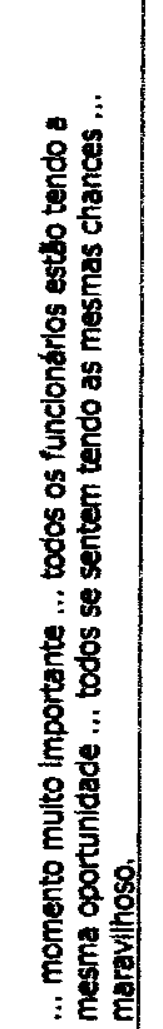 & 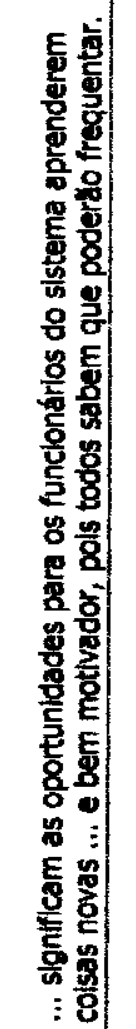 & 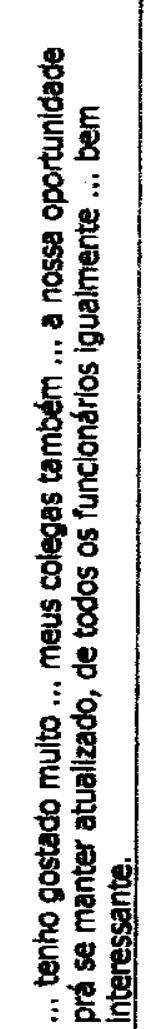 & 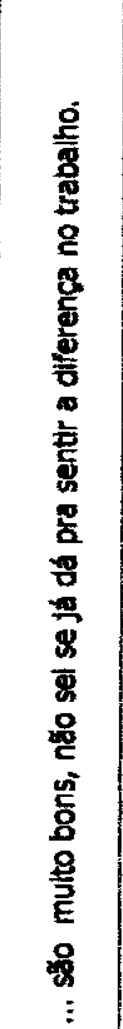 & 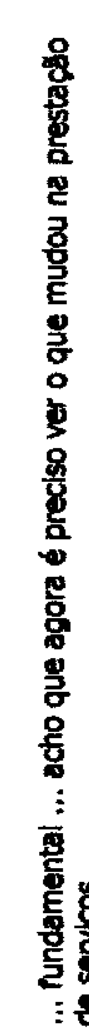 \\
\hline & & 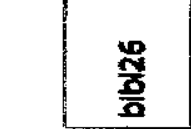 & 兽 & $\frac{\mathrm{o}}{\frac{\mathrm{z}}{\mathbf{a}}}$ & 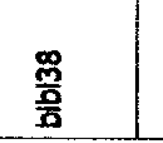 & 置 & $\frac{\vec{z}}{\vec{z}}$ & $\frac{\infty}{\overline{0}}$ & 苛 \\
\hline
\end{tabular}




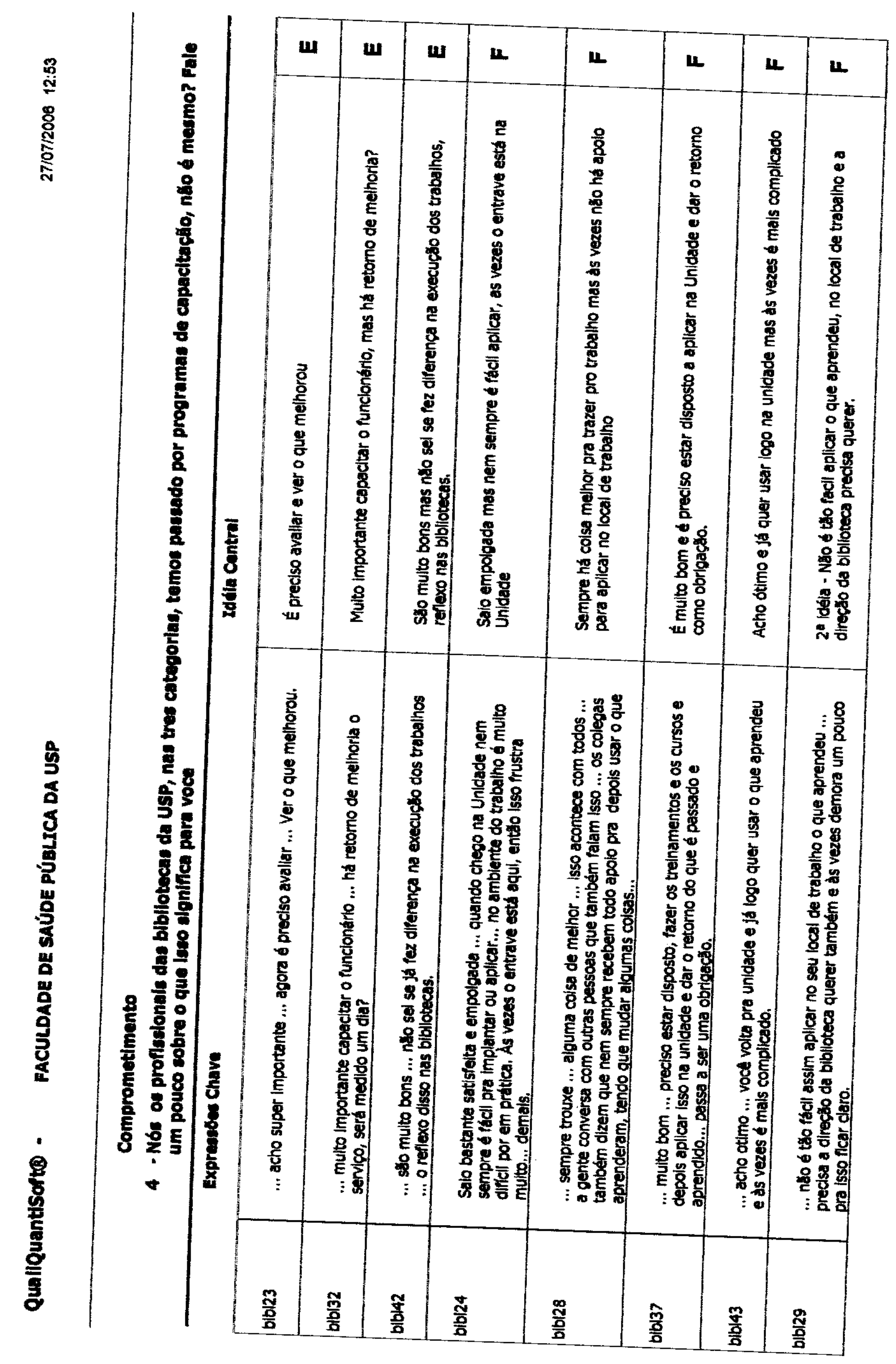




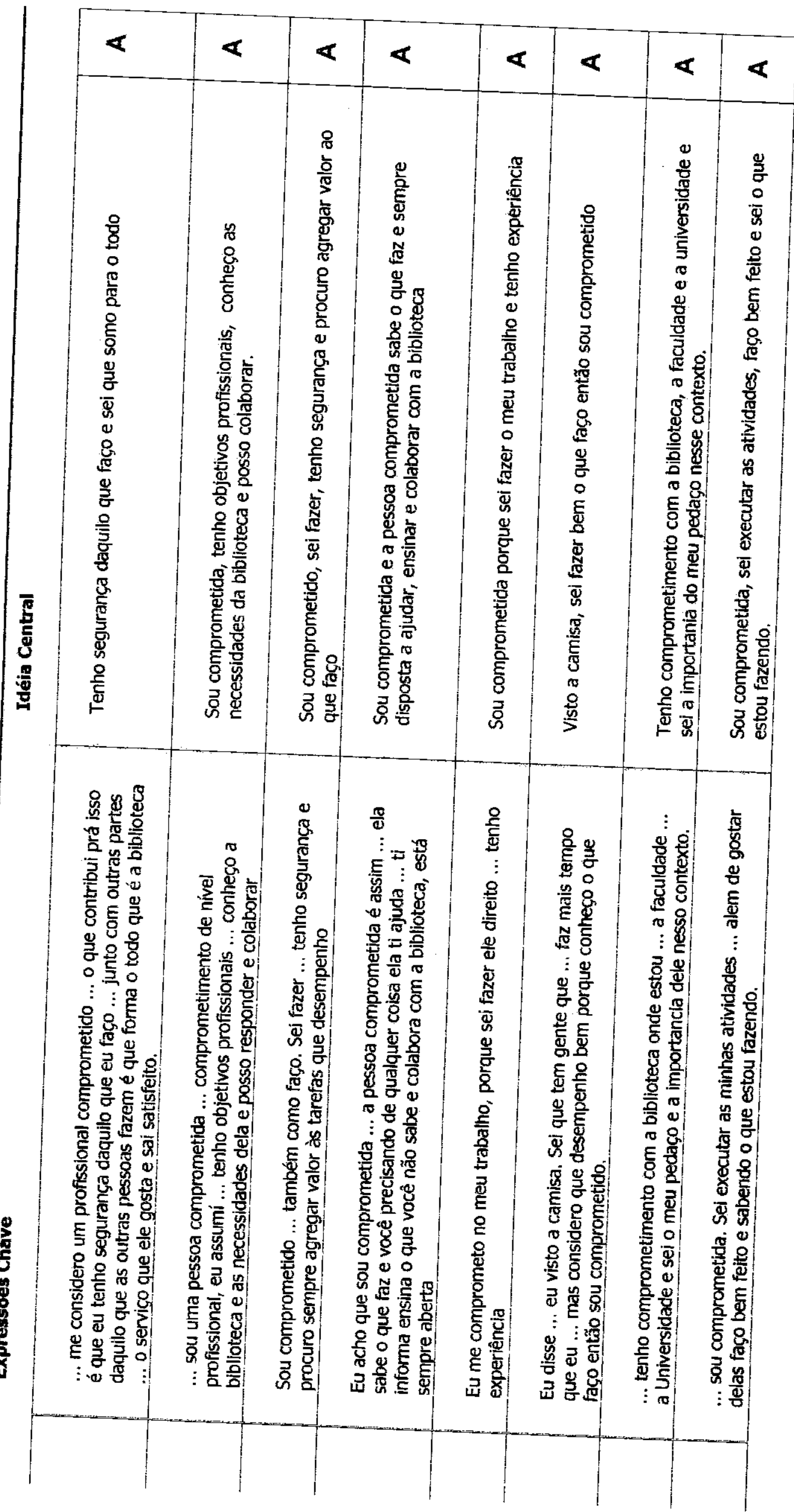




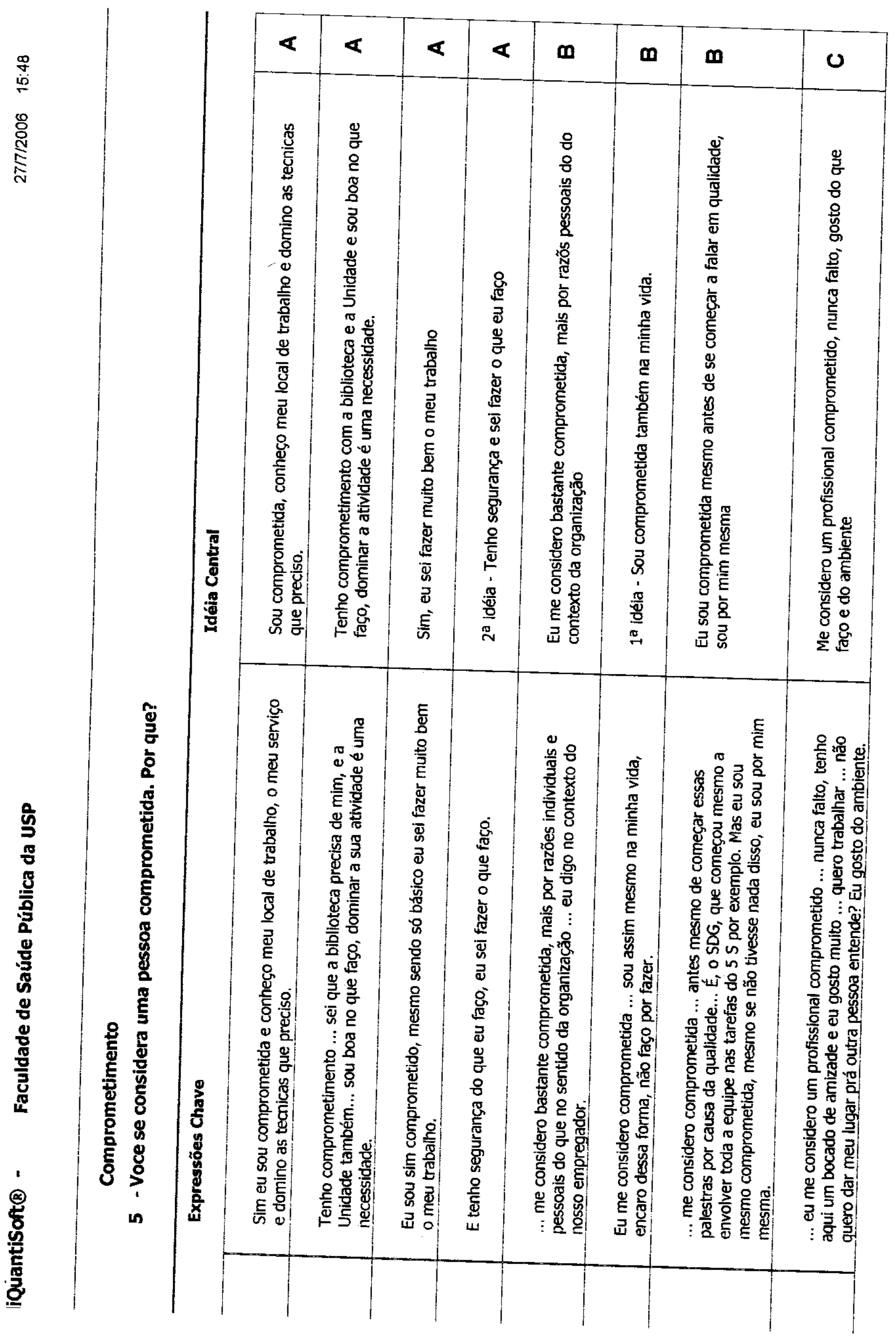




\begin{tabular}{|c|c|c|c|c|c|c|c|}
\hline 0 & 0 & 0 & 0 & 0 & 0 & 0 & 0 \\
\hline 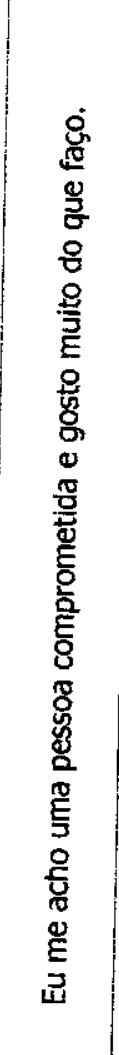 & 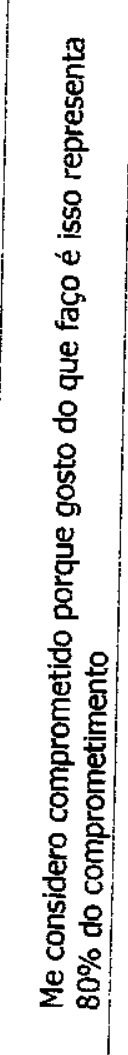 & 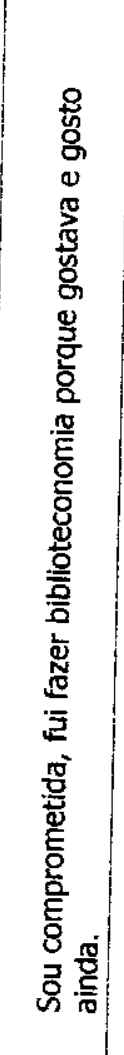 & 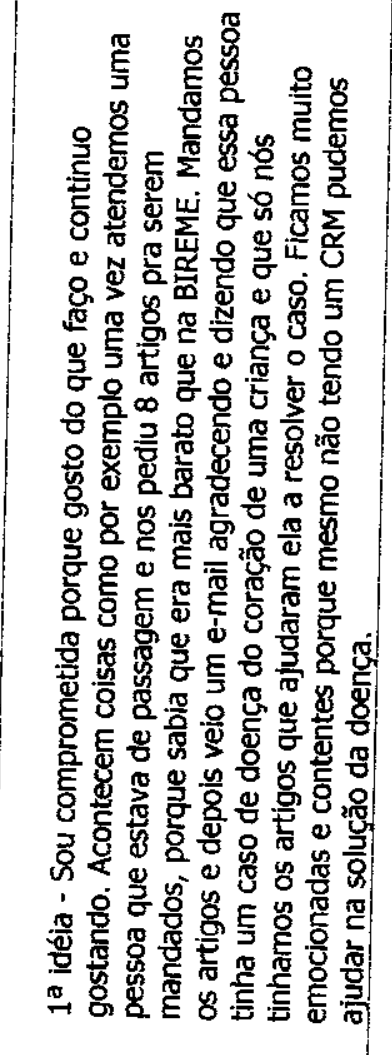 & 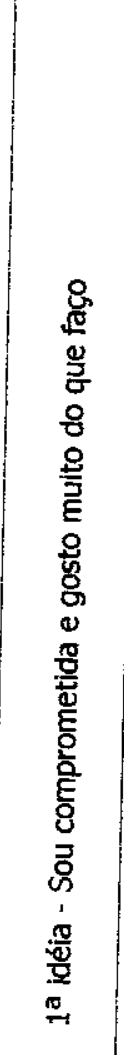 & 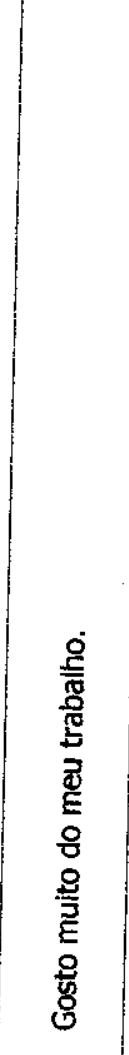 & 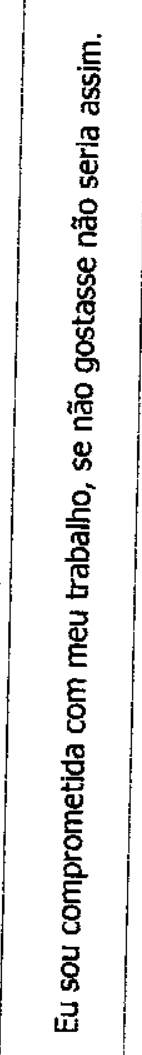 & 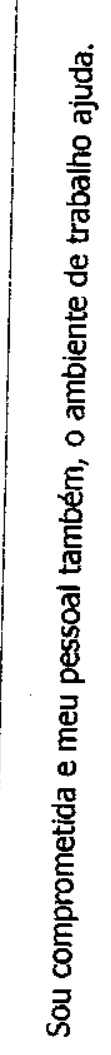 \\
\hline 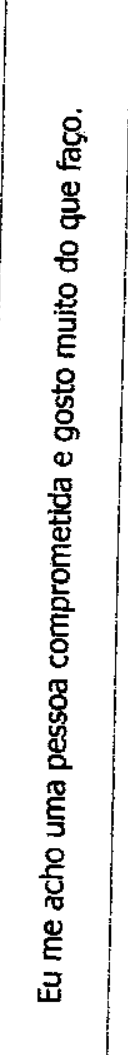 & 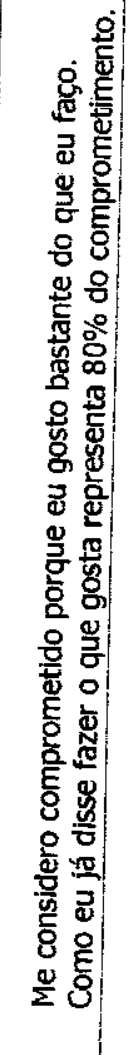 & 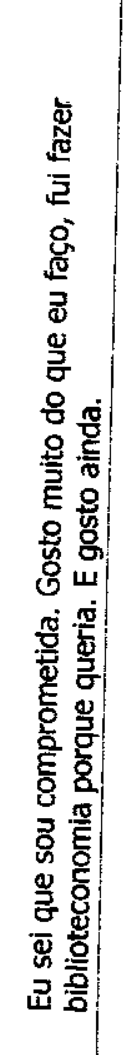 & 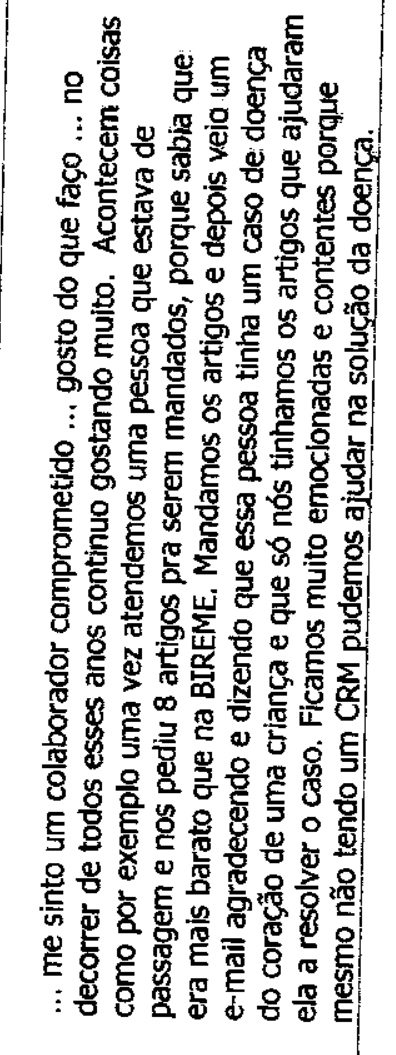 & 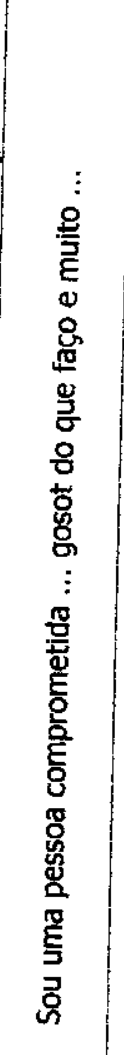 & 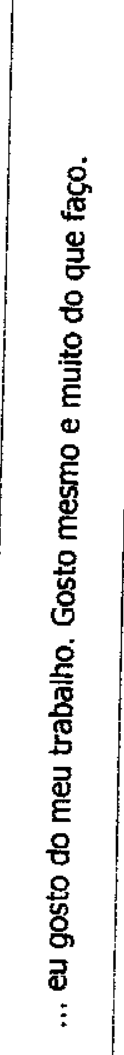 & 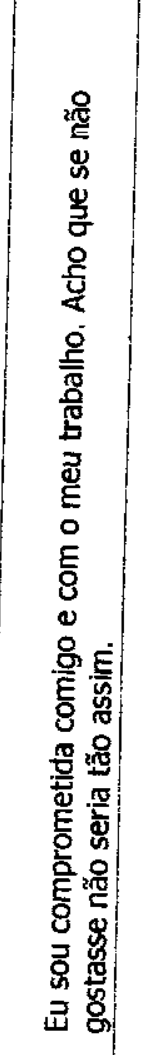 & 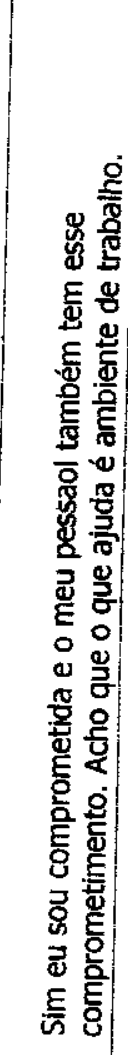 \\
\hline & & & & & & & \\
\hline
\end{tabular}




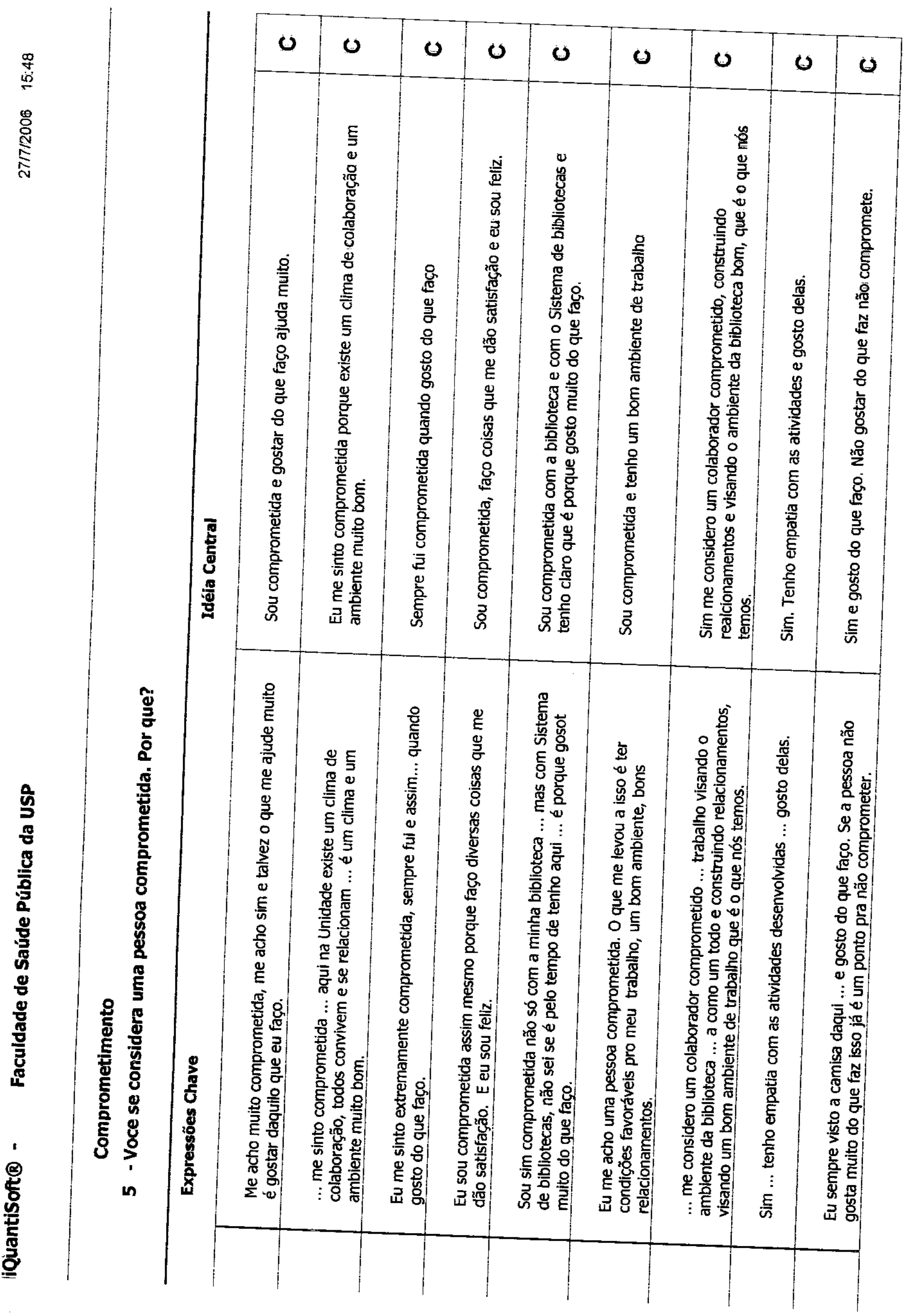




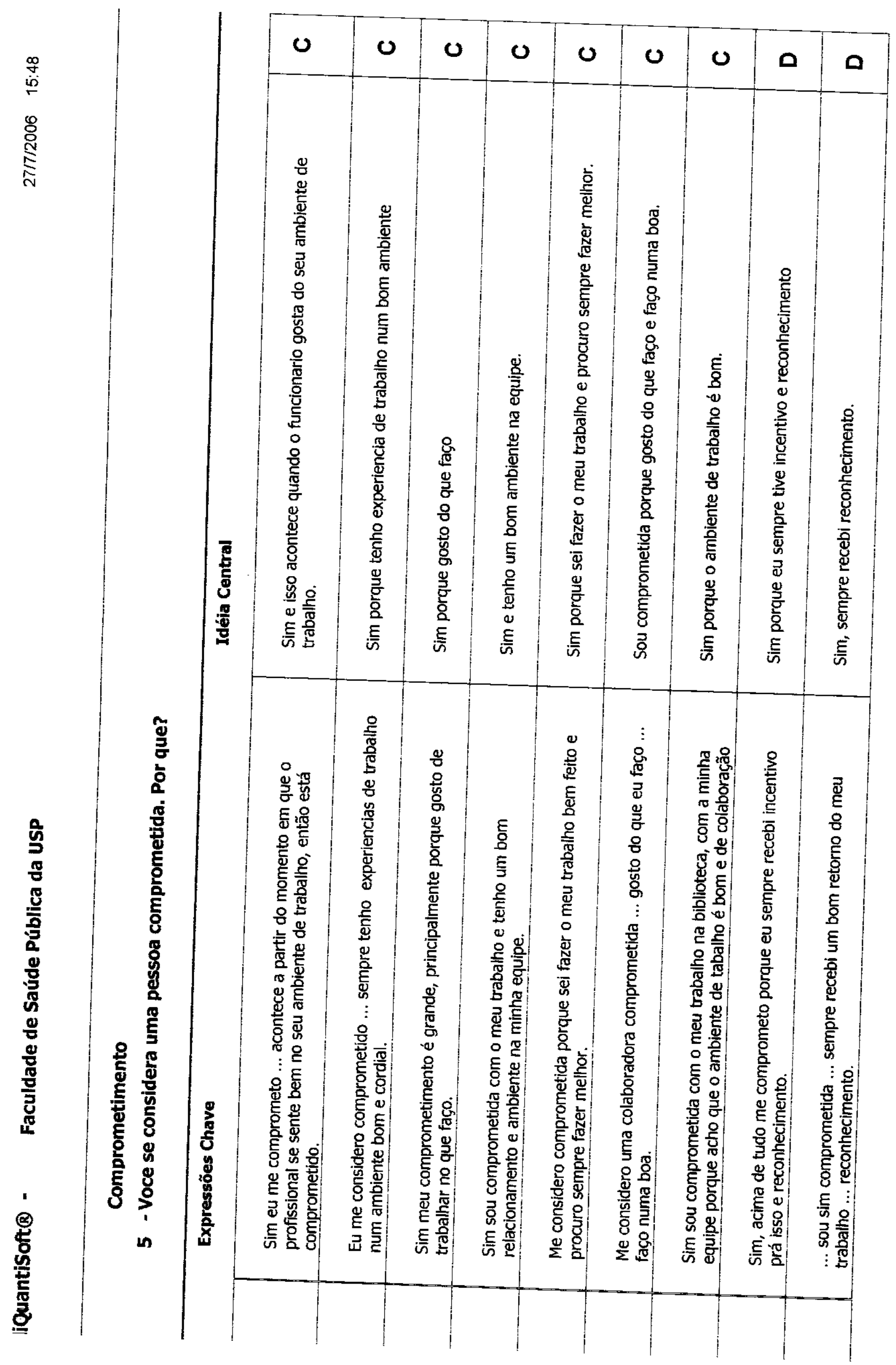




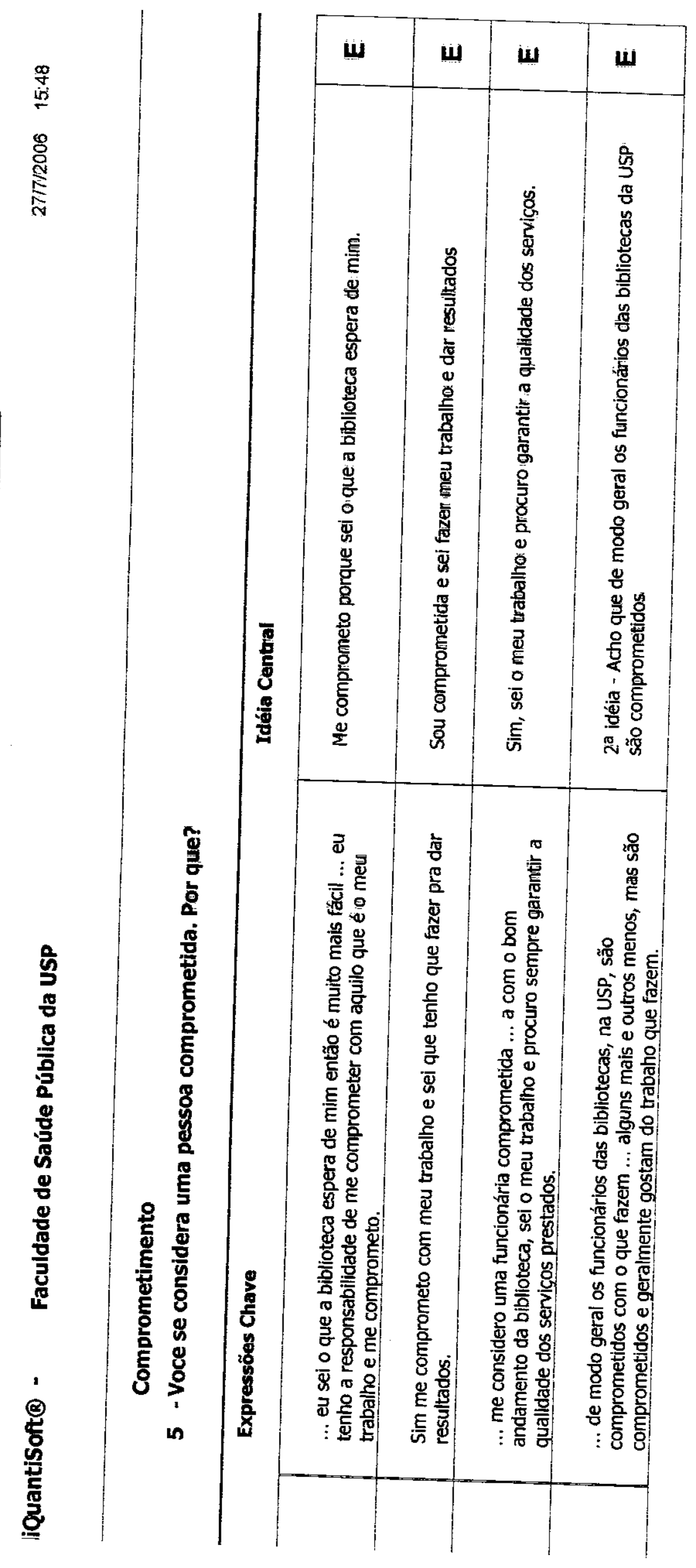




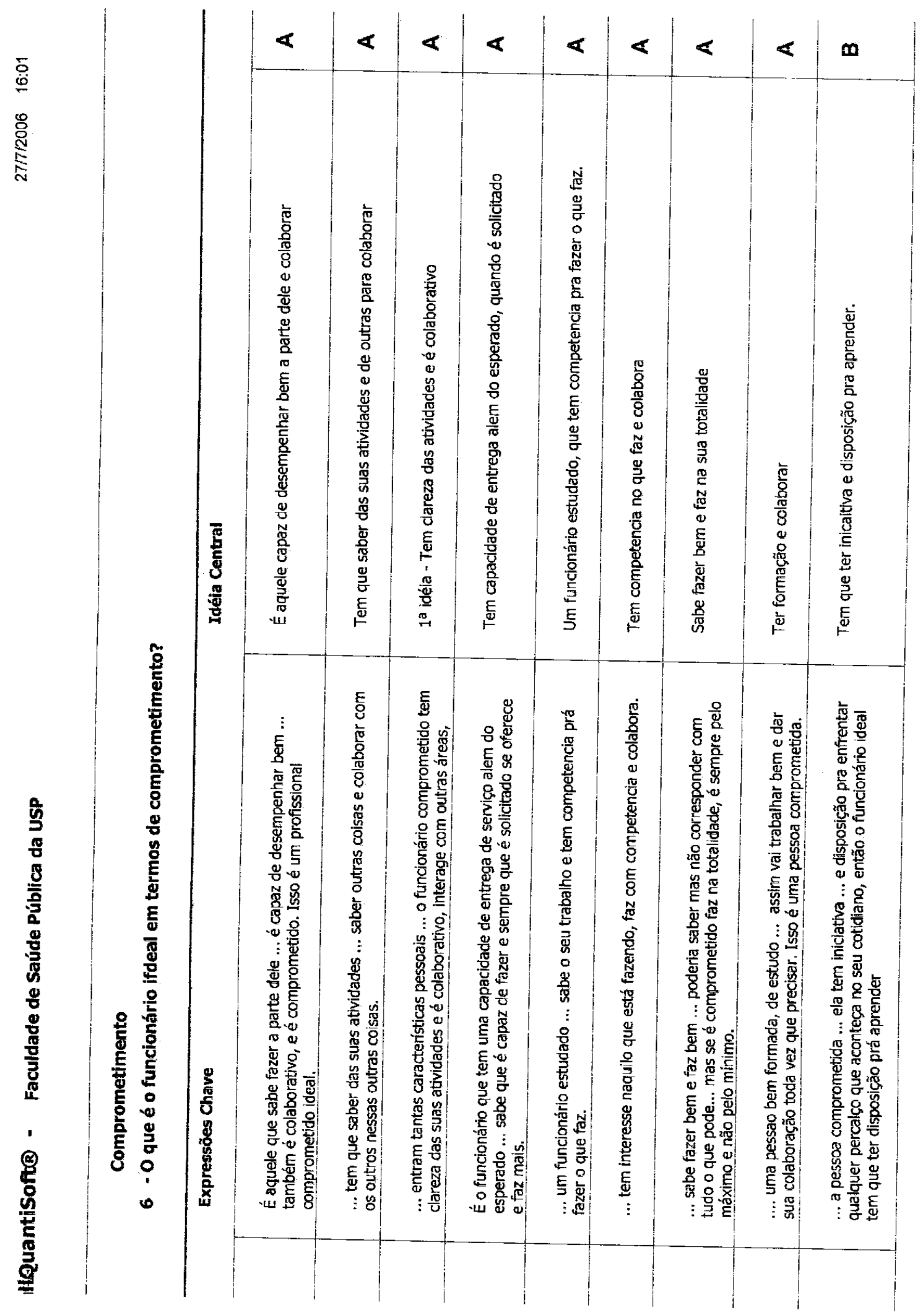




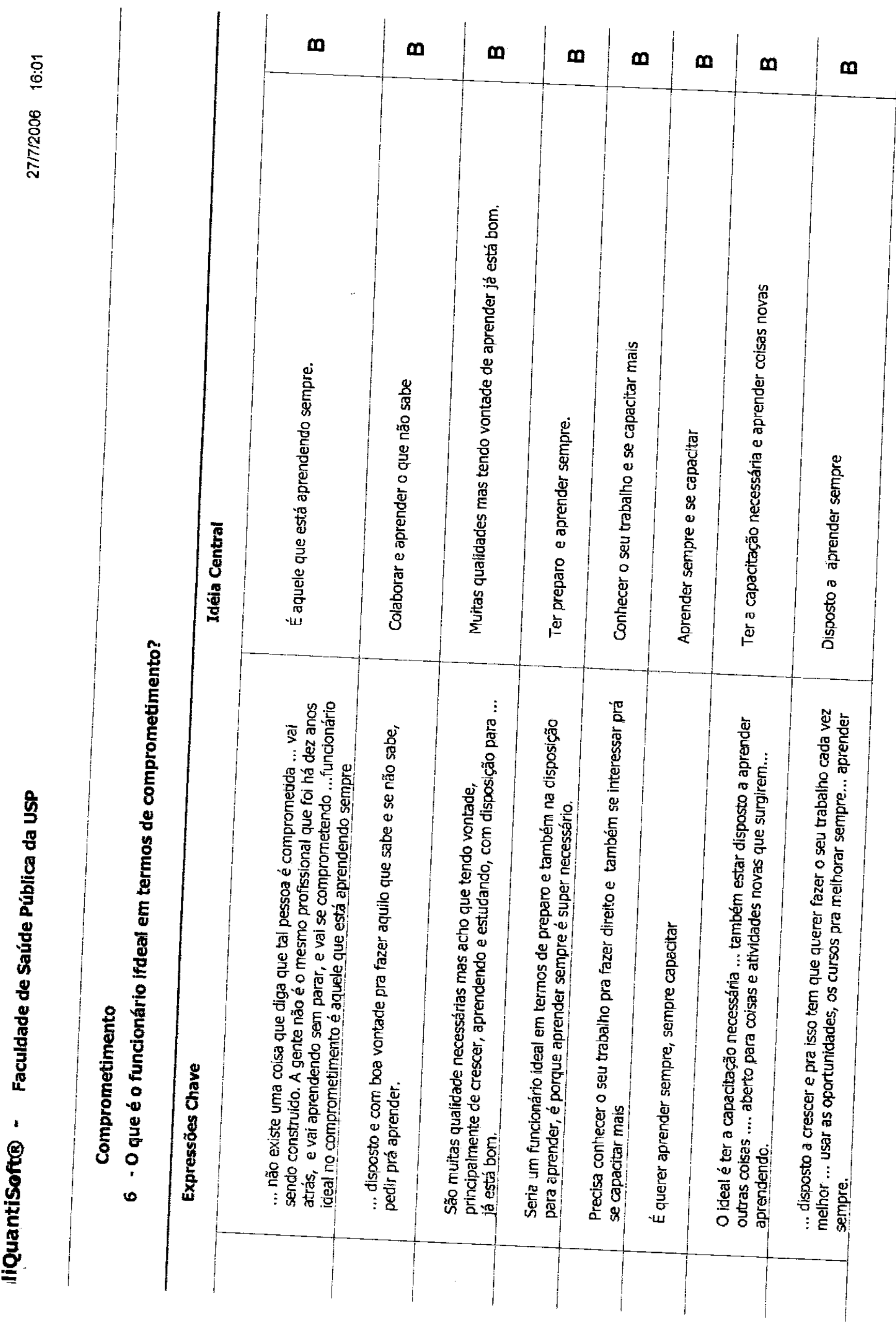




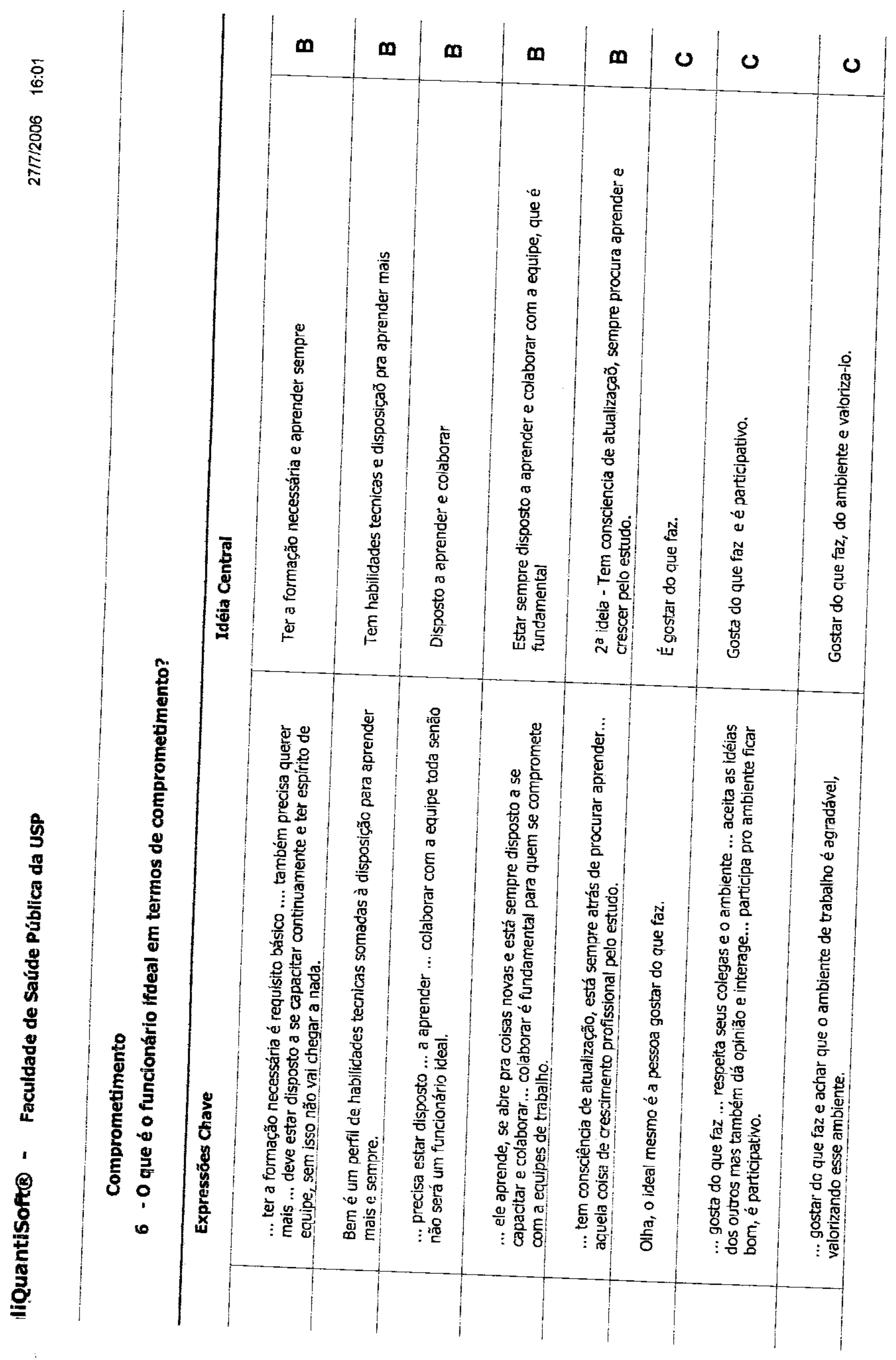




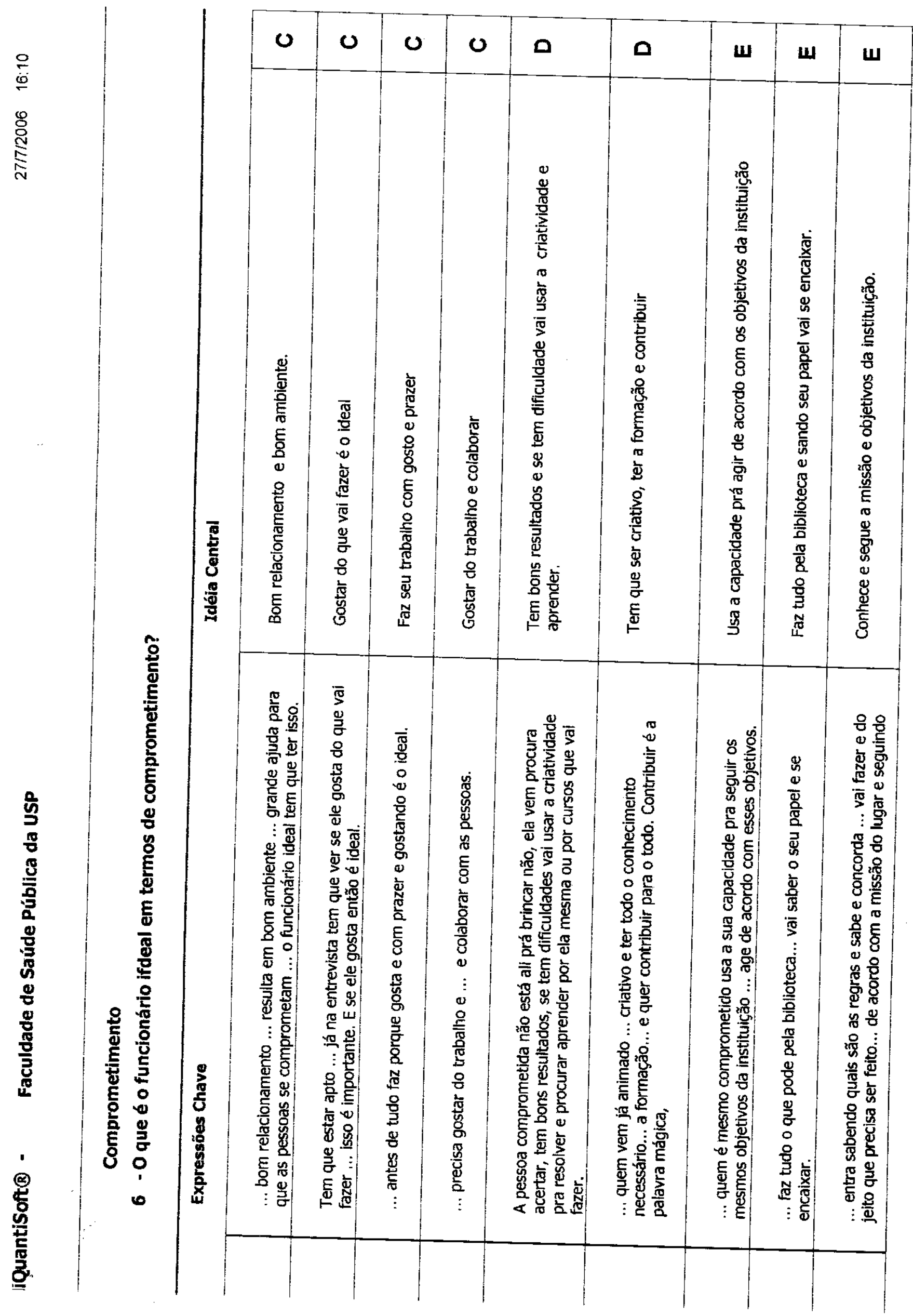




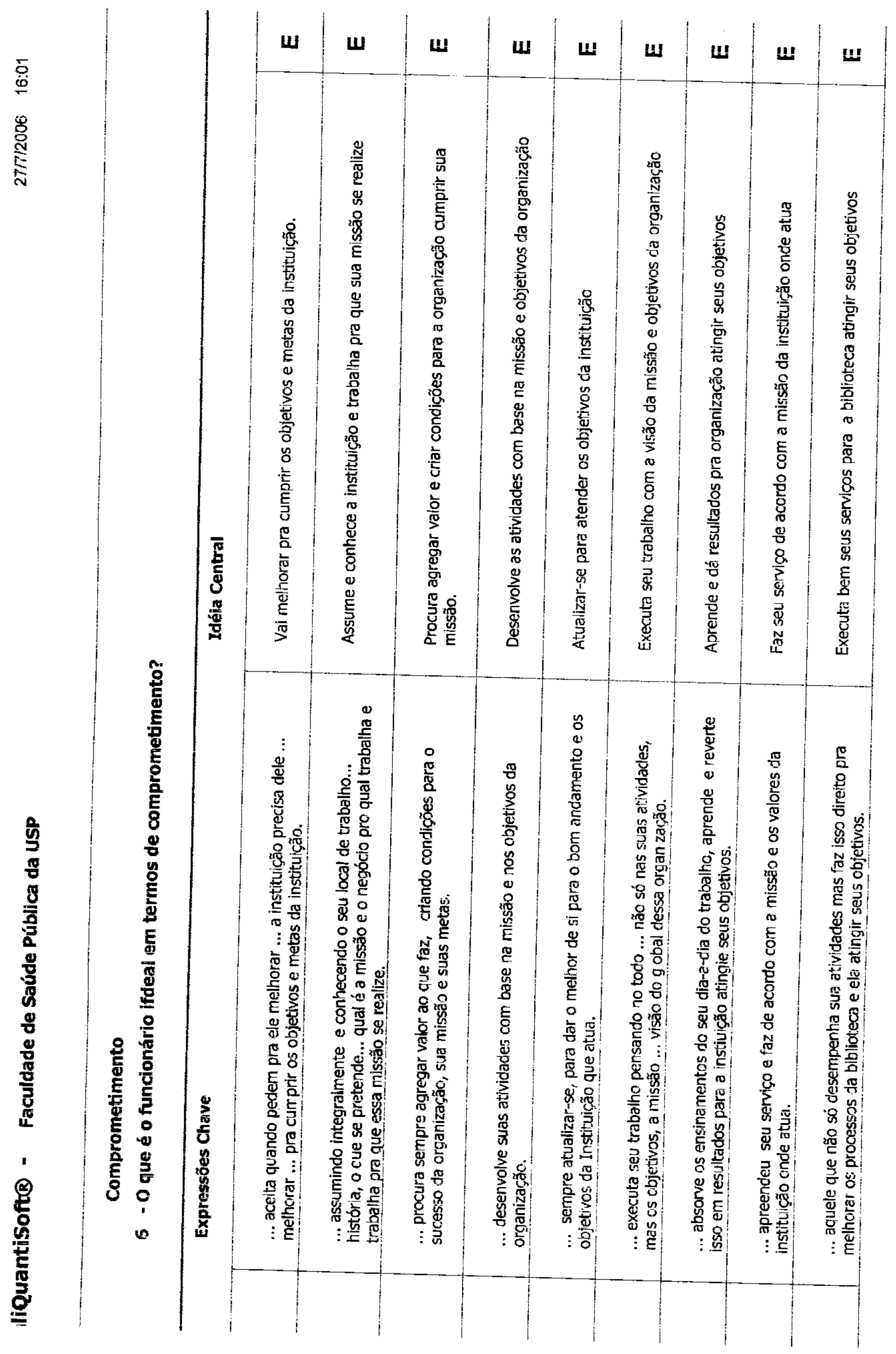




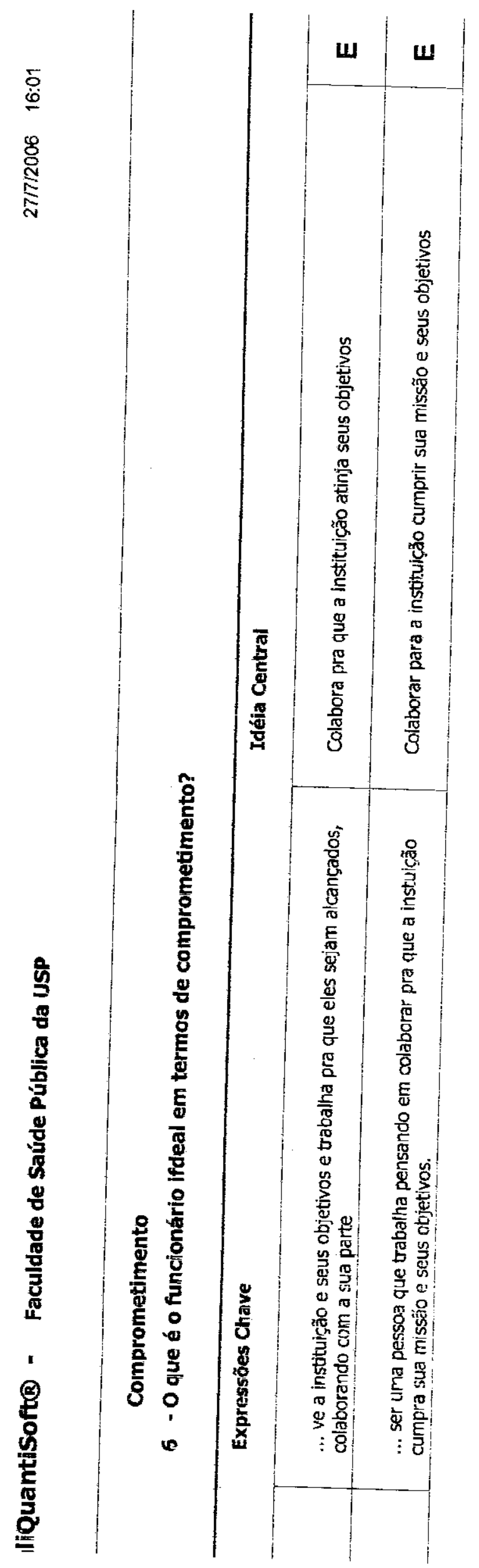

